Keywords: Plutonium Metal, Dissolution, H-Canyon

Retention: Permanent

\title{
Dissolution of Plutonium Metal in 8-10 M Nitric Acid
}

T. S. Rudisill and R. A. Pierce

February 2012

Savannah River National Laboratory Savannah River Nuclear Solutions, LLC Aiken, SC 29808

Prepared for the U.S. Department of Energy under contract number DE-AC09-08SR22470.

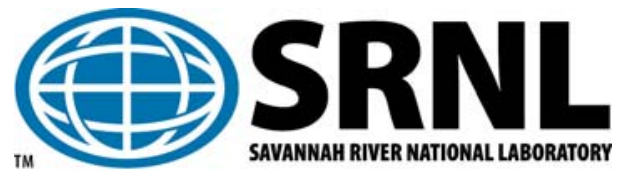


SRNL-STI-2012-00043

Revision 0

\section{DISCLAIMER}

This work was prepared under an agreement with and funded by the U.S. Government. Neither the U.S. Government or its employees, nor any of its contractors, subcontractors or their employees, makes any express or implied:

1. warranty or assumes any legal liability for the accuracy, completeness, or for the use or results of such use of any information, product, or process disclosed; or

2. representation that such use or results of such use would not infringe privately owned rights; or

3. endorsement or recommendation of any specifically identified commercial product, process, or service.

Any views and opinions of authors expressed in this work do not necessarily state or reflect those of the United States Government, or its contractors, or subcontractors.

\section{Printed in the United States of America \\ Prepared for \\ U.S. Department of Energy}




\section{REVIEWS AND APPROVALS}

AUTHORS:

T. S. Rudisill, Separation and Actinide Science Programs

R. A. Pierce, Separation and Actinide Science Programs TECHNICAL REVIEW:

A. E. Visser, Separation and Actinide Science Programs

W. H. Clifton, Jr., H-Canyon Engineering APPROVAL:

S. D. Fink, Manager

Date

Separation and Actinide Science Programs

S. L. Marra, Manager

Date

Environmental \& Chemical Process Technology Research Programs

W. G. Dyer, Manager

$\mathrm{H}$-Canyon Engineering

\section{Date}

Date

Date

Date 


\section{EXECUTIVE SUMMARY}

The H-Canyon facility will be used to dissolve $\mathrm{Pu}$ metal for subsequent purification and conversion to plutonium dioxide $\left(\mathrm{PuO}_{2}\right)$ using Phase II of HB-Line. To support the new mission, the development of a Pu metal dissolution flowsheet which utilizes concentrated (8-10 M) nitric acid $\left(\mathrm{HNO}_{3}\right)$ solutions containing potassium fluoride $(\mathrm{KF})$ is required. Dissolution of Pu metal in concentrated $\mathrm{HNO}_{3}$ is desired to eliminate the need to adjust the solution acidity prior to purification by anion exchange. The preferred flowsheet would use 8-10 $\mathrm{M} \mathrm{HNO}_{3}, 0.015-0.07 \mathrm{M}$ $\mathrm{KF}$, and $0.5-1.0 \mathrm{~g} / \mathrm{L} \mathrm{Gd}$ to dissolve the $\mathrm{Pu}$ up to $6.75 \mathrm{~g} / \mathrm{L}$. An alternate flowsheet would use 8-10 $\mathrm{M} \mathrm{HNO}_{3}, 0.1-0.2 \mathrm{M} \mathrm{KF}$, and 1-2 g/L B to dissolve the Pu. The targeted average Pu metal dissolution rate is $20 \mathrm{mg} / \mathrm{min}-\mathrm{cm}^{2}$, which is sufficient to dissolve a "standard" 2250-g Pu metal button in $24 \mathrm{~h}$.

Plutonium metal dissolution rate measurements showed that if $\mathrm{Gd}$ is used as the nuclear poison, the optimum dissolution conditions occur in $10 \mathrm{M} \mathrm{HNO}_{3}, 0.04-0.05 \mathrm{M} \mathrm{KF}$, and 0.5-1.0 g/L Gd at 112 to $116{ }^{\circ} \mathrm{C}$ (boiling). These conditions will result in an estimated Pu metal dissolution rate of $\sim 11-15 \mathrm{mg} / \mathrm{min}-\mathrm{cm}^{2}$ and will result in dissolution times of 36-48 h for standard buttons. The recommended minimum and maximum KF concentrations are $0.03 \mathrm{M}$ and $0.07 \mathrm{M}$, respectively. The maximum KF concentration is dictated by a potential room-temperature Pu-Gd-F precipitation issue at low Pu concentrations.

Testing at 8-10 $\mathrm{M} \mathrm{HNO}_{3}, 0.1-0.2 \mathrm{M} \mathrm{KF}$, and 1-2 g/L B demonstrated that $\sim 20-35 \mathrm{mg} / \mathrm{min}-\mathrm{cm}^{2} \mathrm{Pu}$ metal dissolution rates can be achieved at 112 to $116{ }^{\circ} \mathrm{C}$ (boiling). The concentration of $\mathrm{B}$ in solution did not have a significant effect on dissolution rate. The data also indicate that lower KF concentrations would yield dissolution rates for B comparable to those observed with Gd at the same $\mathrm{HNO}_{3}$ concentration and dissolution temperature. The low-temperature $\mathrm{Pu}$ precipitation issue associated with the use of $\mathrm{Gd}$ does not occur for dissolution with $\mathrm{B}$; however, the $\mathrm{B}$ concentration must be maintained below the $\mathrm{H}_{3} \mathrm{BO}_{3}$ solubility limit and the $\mathrm{KF}$ concentration must not exceed the value where $\mathrm{B}$ precipitates as $\mathrm{KBF}_{4}$.

To confirm that the optimal conditions identified by the dissolution rate measurements can be used to dissolve $\mathrm{Pu}$ metal up to $6.75 \mathrm{~g} / \mathrm{L}$ in the presence of representative concentrations of $\mathrm{Fe}$ and Gd or B, a series of experiments was performed to demonstrate the flowsheets. In three of the five experiments, the offgas generation rate during the dissolution was measured and samples were analyzed for hydrogen gas $\left(\mathrm{H}_{2}\right)$. The use of $10 \mathrm{M} \mathrm{HNO}_{3}$ containing 0.03-0.05 M KF, 0.5-1.0 g/L Gd, and 1.9 g/L Fe resulted in complete dissolution of the metal in 2.0-3.5 h. When B was used as the neutron poison, $10 \mathrm{M} \mathrm{HNO}_{3}$ solutions containing $0.05-0.1 \mathrm{M} \mathrm{KF}, 1.9 \mathrm{~g} / \mathrm{L} \mathrm{Fe}$, and $1 \mathrm{~g} / \mathrm{L} \mathrm{B}$ resulted in complete dissolution of the metal in 0.75-2.0 h. All experiments were performed using a dissolution temperature of $100{ }^{\circ} \mathrm{C}$. No residues were observed following the dissolutions in either the Gd or B system.

Dissolution rates estimated using data from the flowsheet demonstrations agreed reasonably well with the measured rates; although, a discrepancy was observed in the Gd system. The estimated rates for experiments performed using the same KF concentration with $1 \mathrm{~g} / \mathrm{L}$ Gd or B were nominally the same. This observation indicates that the presence of $1 \mathrm{~g} / \mathrm{L} \mathrm{Gd}$ or $\mathrm{B}$ in the dissolving solution had about the same effect on the dissolution rate. The predominant Pu valence in the dissolving solution was $\mathrm{Pu}(\mathrm{IV})$. The concentration of $\mathrm{Pu}(\mathrm{VI})$ was evaluated by UV-visible spectroscopy and was estimated to be significantly less than $1 \mathrm{wt} \%$. 
The offgas generation rates and $\mathrm{H}_{2}$ concentrations measured in the offgas from experiments performed using $10 \mathrm{M} \mathrm{HNO}_{3}$ containing $0.05 \mathrm{M} \mathrm{KF}, 1.9 \mathrm{~g} / \mathrm{L}$ Fe and either $1 \mathrm{~g} / \mathrm{L} \mathrm{Gd}$ or B were approximately the same. These data support the conclusion that the presence of either $1 \mathrm{~g} / \mathrm{L} \mathrm{Gd}$ or $\mathrm{B}$ had the same general effect on the dissolution rate. The calculated offgas generation during the dissolutions was $0.6 \mathrm{~mol}$ offgas $/ \mathrm{mol}$ of $\mathrm{Pu}$. The $\mathrm{H}_{2}$ concentration measured in the offgas from the dissolution using $\mathrm{Gd}$ as the neutron poison was approximately 0.5 vol \%. In the B system, the $\mathrm{H}_{2}$ ranged from nominally 0.8 to $1 \mathrm{vol} \%$ which is about the same as measured in the Gd system within the uncertainty of the analysis. The offgas generation rate for the dissolution performed using $10 \mathrm{M} \mathrm{HNO}_{3}$ containing $0.03 \mathrm{M} \mathrm{KF}, 0.5 \mathrm{~g} / \mathrm{L} \mathrm{Gd}$, and $1.9 \mathrm{~g} / \mathrm{L}$ Fe was approximately a factor of two less than produced in the other dissolutions; however, the concentration of $\mathrm{H}_{2}$ measured in the offgas was higher. The adjusted concentration ranged from 2.7 to $8.8 \mathrm{vol} \%$ as the dissolution proceeded. Higher concentrations of $\mathrm{H}_{2}$ occur when the $\mathrm{Pu}$ dissolution proceeds by a metal/acid reaction rather than nitrate oxidation. The higher $\mathrm{H}_{2}$ concentration could be attributed to the reduced activity of the fluoride due to complexation with $\mathrm{Pu}$ as the dissolution progressed.

Dissolution of Pu metal at $20{ }^{\circ} \mathrm{C}$ in $10 \mathrm{M} \mathrm{HNO}_{3}$ containing $0.05 \mathrm{M} \mathrm{KF}$ showed that the Pu metal dissolves slowly without any visible gas generation. As the Pu metal dissolves, it forms a moredense Pu-bearing solution which sank to the bottom of the dissolution vessel. The dissolved $\mathrm{Pu}$ did not form a boundary layer around the sample and failed to distribute homogeneously due to minimal (thermally-induced) mixing. This indicates that in the $\mathrm{H}$-Canyon dissolver insert, the $\mathrm{Pu}$ will diffuse out of the insert into the bulk dissolver solution where it will disperse. At $35{ }^{\circ} \mathrm{C}$, the $\mathrm{Pu}$ metal dissolved without visible gas generation. However, due to thermal currents caused by maintaining the solution at $35{ }^{\circ} \mathrm{C}$, the dissolved Pu distributed evenly throughout the dissolver solution. It did not form a boundary layer around the sample. 


\section{TABLE OF CONTENTS}

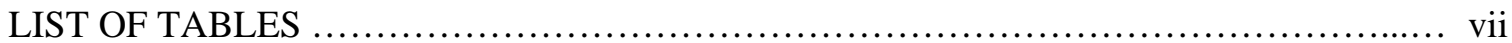

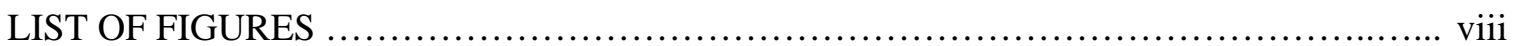

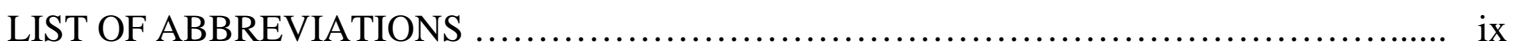

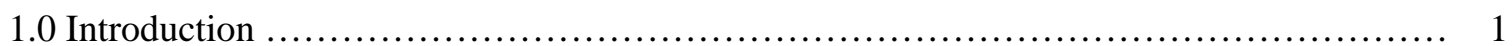

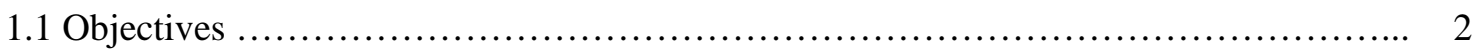

2.0 Experimental Procedure ...................................................... 2

2.1 Dissolution Rate Measurements .............................................. 2

2.2 Low-Temperature Dissolution ............................................ 5

2.3 Flowsheet Demonstrations ................................................... 5

2.3.1 Test Conditions .......................................................... 5

2.3.2 Preparation of Pu Metal .................................................. 6

2.3.3 Pu Metal Dissolving System ........................................... 6

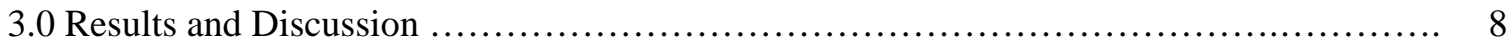

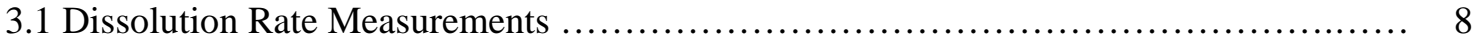

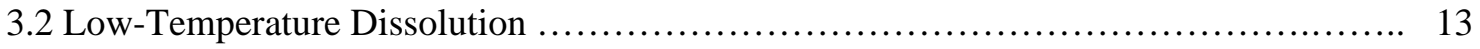

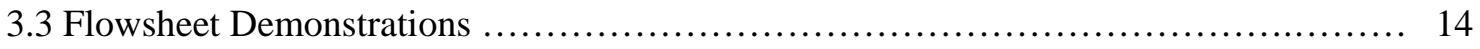

3.3.1 General Observations .................................................... 14

3.3.2 Sample Analysis ........................................................... 14

3.3.3 Initial Dissolution Rates ...................................................... 20

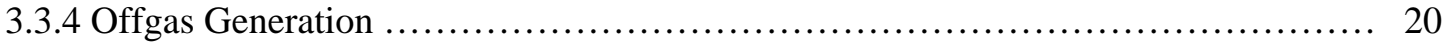

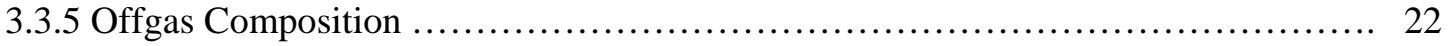

3.3.6 H-Canyon Dissolver Purge .................................................................................. 23

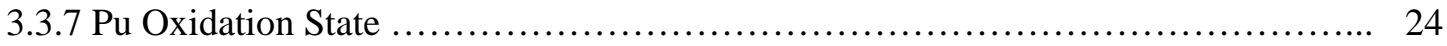

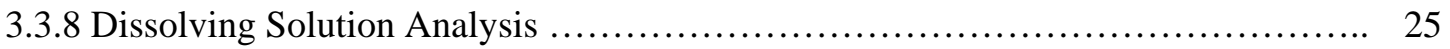

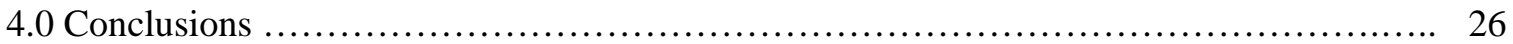

5.0 Flowsheet Recommendations ..................................................... 27

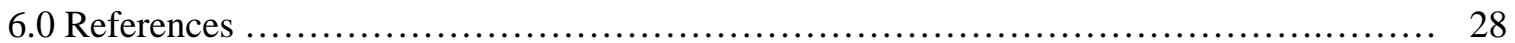

Appendix A Dissolution Experiment Pu1 ........................................ 29

Appendix B Radiochemical Solution Analysis .................................... 33

Appendix C Offgas Characterization ........................................... 51

Appendix D Dissolving Solution Characterization .......................................................... 58 


\section{LIST OF TABLES}

Table 2-1. Test Conditions for Dissolution Rate Screening Studies at $100{ }^{\circ} \mathrm{C} \ldots \ldots \ldots \ldots \ldots . . . .4$

Table 2-2. Test Conditions for Pu Metal Dissolution Experiments …...................... 6

Table 2-3. Mass and Dimensions of Pu Metal Used in Flowsheet ............................................. 6 Demonstration Experiments

Table 3-1. Dissolution Time and Weight Measurements ............................... 9

Table 3-2. Dissolution Rate Calculations ............................................ 9

Table 3-3 Calculated Linear Penetration Rates at $112{ }^{\circ} \mathrm{C}$ for 0 to $6 \mathrm{~g} / \mathrm{L} \mathrm{Pu} \ldots \ldots \ldots \ldots \ldots \ldots . \ldots 13$

Table 3-4. Comparison of Pu Concentrations Based on Corrected Value and Metal Mass ..... 17

Table 3-5. Time Required for Complete Dissolution of Pu Metal Coupons .................. 17

Table 3-6. Comparison of Pu Metal Dissolution Rates ...................................... 20

Table 3-7. Offgas Volumes Collected during Pu Dissolution Experiments ................... 21

Table 3-8. Offgas Generation per Mole of Dissolve Pu ............................ 22

Table 3-9. Composition of Offgas from Pu Metal Dissolutions in $10 \mathrm{M} \mathrm{HNO}_{3} \ldots \ldots \ldots \ldots \ldots \ldots . . . . . . . . . . . . .23$

Table 3-10. $\mathrm{H}_{2}$ Generation Rate from an H-Canyon Dissolver ................................................ 24

Table 3-11. Minimum Purge Rate for an H-Canyon Dissolver ................................................. 24

Table 3-12. Analysis of Pu Metal Dissolving Solutions ........................................................... 25

Table 3-13. Free Acid Analysis for Pu Metal Dissolving Solutions ........................................... 26 


\section{LIST OF FIGURES}

Figure 1-1. Estimated Times for the Dissolution of a Nominal Pu Metal Button ............ 1

Figure 2-1. Pu Metal Coupons - Source Material for Test Samples ….................. 3

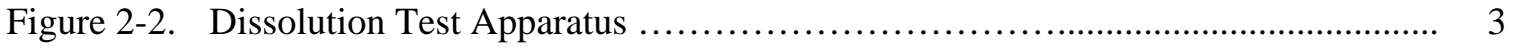

Figure 2-3. Dissolution of a Plutonium Metal Sample- Test 8G …................... 5

Figure 2-4. Pu Metal Dissolving System …....................................... 7

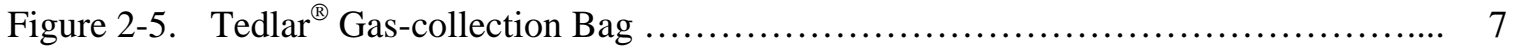

Figure 3-1. Effect of $\mathrm{HNO}_{3}, \mathrm{KF}$, and Temperature on Dissolution Rate for 0.5-1.0 g/L Gd.... 10

Figure 3-2. Effect of B, KF, and Temperature on Dissolution Rate for 1-2 g/L B ................. 10 in $10 \mathrm{M} \mathrm{HNO}_{3}$

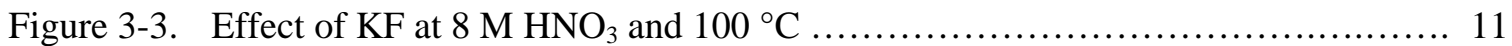

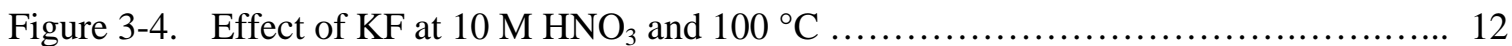

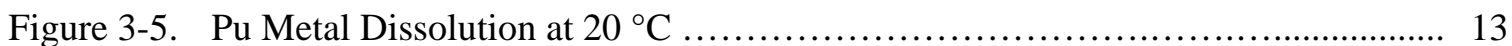

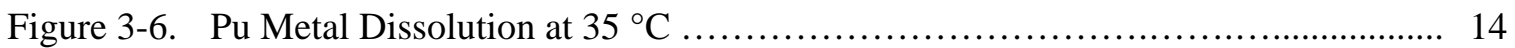

Figure 3-7. Corrected Actinide Concentrations in Experiment Pu2 ........................ 15

Figure 3-8. Corrected Actinide Concentrations in Experiment Pu3 ....................... 15

Figure 3-9. Corrected Actinide Concentrations in Experiment Pu4 ...................... 16

Figure 3-10. Corrected Actinide Concentrations in Experiment Pu5 ...................... 16

Figure 3-11. Actinide Metal Dissolution in Experiment Pu2 …......................... 18

Figure 3-12. Actinide Metal Dissolution in Experiment Pu3 …........................ 18

Figure 3-13. Actinide Metal Dissolution in Experiment Pu4 ............................ 19

Figure 3-14. Actinide Metal Dissolution in Experiment Pu5 …........................ 19

Figure 3-15. Offgas Generation during Pu Metal Dissolution Experiments ................. 21

Figure 3-16.. UV-visible Spectra of Pu Dissolving Solutions .................................................. 25 


\section{LIST OF ABBREVIATIONS}

$\begin{array}{ll}\mathrm{Am}_{\text {corrected }} & \text { corrected concentration of Am } \\ \mathrm{GC} & \text { gas chromatograph } \\ \mathrm{GPHA} & \text { gamma pulse height analysis } \\ \mathrm{dpm} & \text { disintegrations per minute } \\ \mathrm{H}_{2} & \text { hydrogen gas } \\ \mathrm{H}_{3} \mathrm{BO}_{3} & \text { boric acid } \\ \mathrm{HCMA} & \text { hot crane maintenance area } \\ \mathrm{ICPES} & \text { inductively-coupled plasma emission spectroscopy } \\ \mathrm{LFL} & \text { lower flammability limit } \\ \mathrm{N}_{2} & \text { nitrogen gas } \\ \mathrm{NO} & \text { nitric oxide } \\ \mathrm{NO}_{2} & \text { nitrogen dioxide } \\ \mathrm{Pu}_{\text {corrected }} & \text { corrected concentration of Pu } \\ \mathrm{PuO} & \text { plutonium dioxide } \\ \mathrm{SRNL}_{2} & \text { Savannah River National Laboratory } \\ \mathrm{SRS} & \text { Savannah River Site } \\ \mathrm{STP} & \text { standard temperature and pressure } \\ \mathrm{UV} & \text { ultraviolet }\end{array}$




\subsection{Introduction}

The dissolution of $\mathrm{Pu}$ metal using $\mathrm{HNO}_{3}$ solutions containing fluoride was investigated at both the Rocky Flats Plant and the Savannah River Site (SRS).[1-7] However, most of the testing was conducted at $\mathrm{HNO}_{3}$ concentrations in the 3-5 $\mathrm{M}$ range and at temperatures $<90{ }^{\circ} \mathrm{C}$ to limit the formation of plutonium dioxide and maximize the rate of dissolution. To support a new mission in $\mathrm{H}$-Canyon, the development of a Pu metal dissolution flowsheet which utilizes 8-10 $\mathrm{M} \mathrm{HNO}_{3}$ solutions containing KF is desired.[8-9] The preferred flowsheet would use 8-10 $\mathrm{M} \mathrm{HNO}_{3}, 0.015-$ $0.07 \mathrm{M} \mathrm{KF}$, and 0.5-1.0 g/L Gd to dissolve the Pu up to $6.75 \mathrm{~g} / \mathrm{L}$. An alternate flowsheet would use 8-10 $\mathrm{M} \mathrm{HNO}_{3}, 0.1-0.2 \mathrm{M} \mathrm{KF}$, and 1-2 g/L B to dissolve the Pu. The higher concentration of $\mathrm{HNO}_{3}$ is required to facilitate the purification of the $\mathrm{Pu}$ solution by anion exchange in the HB-Line facility without adjusting the acidity prior to column loading. Prior to transferring the solution to HB-Line, aluminum nitrate must be added to complex the fluoride to improve the anion exchange Pu recovery efficiency. Either Gd or B is required for use as a neutron poison to support the double contingency analysis for the Pu dissolution process. The dissolution of the $\mathrm{Pu}$ metal in H-Canyon may begin as early as August 2012.

Two H-Canyon dissolvers are being considered for the Pu metal dissolution: 6.1 D (with $5250 \mathrm{~L}$ minimum volume and $7000 \mathrm{~L}$ operating volume) and 6.4 D (with 10,500 L minimum volume and 14,000 L maximum volume). The selection of operating conditions will target a total dissolution cycle of 24 hours, although longer times are not necessarily prohibitive. Holcomb estimated the times needed to dissolve a Pu metal button with a nominal weight of $2250 \mathrm{~g}$ and surface area of $171.2 \mathrm{~cm}^{2}$ (Figure 1-1).[7] Based on Holcomb's calculations, a nominal alpha phase button would require a cumulative dissolution rate of $\sim 20 \mathrm{mg} / \mathrm{min}-\mathrm{cm}^{2}$ to dissolve within 24 hours. Materials with higher surface areas will dissolve faster than a nominal button.

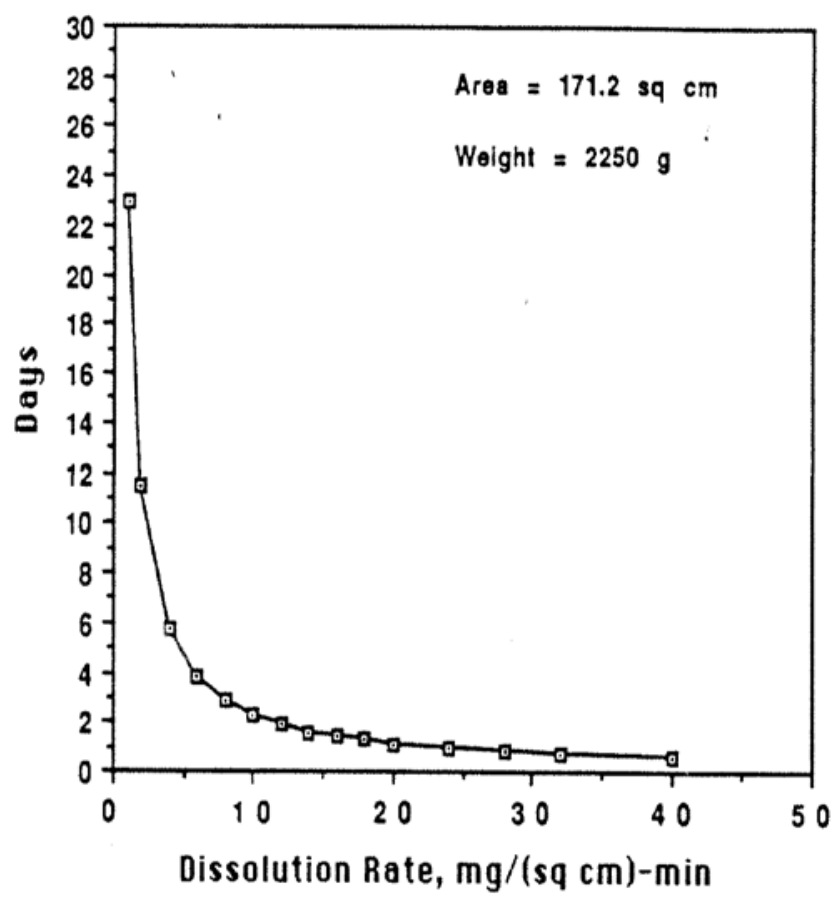

Figure 1-1. Estimated Times for the Dissolution of a Nominal Pu Metal Button[7] 
Previous dissolution studies for $\mathrm{Pu}$ and $\mathrm{U}$ metal composite materials in $6 \mathrm{M} \mathrm{HNO}_{3}$ found that 0.75-1.0 g/L Gd was soluble below 0.05 M KF.[10] The same study indicated that a KF concentration of $0.072 \mathrm{M}$ could result in a Pu-Gd-F residue, and that the residue solubility increased with increasing temperature. It is also known that as the Pu concentration increases from 0 to $6.75 \mathrm{~g} / \mathrm{L} \mathrm{Pu}$, the likelihood of forming a Pu-Gd-F precipitate decreases.[11] The lowtemperature Pu precipitation issue associated with the use of $\mathrm{Gd}$ does not occur for dissolutions performed with $\mathrm{B}$; however, the $\mathrm{B}$ concentration must be maintained below the $\mathrm{H}_{3} \mathrm{BO}_{3}$ solubility limit and the $\mathrm{KF}$ concentration must not exceed the value where $\mathrm{B}$ precipitates as $\mathrm{KBF}_{4}$.

To prepare for dissolution in an H-Canyon dissolver, a $3013 \mathrm{Pu}$ storage container will be transferred to HB-Line where the inner containers will be cut open and the contents transferred to dissolvable steel cans (containing no polymeric gasket materials). The cans will then be bagged out of the glovebox into a nylon bag and transferred to the Hot Crane Maintenance Area (HCMA). In the HCMA, the steel cans will be loaded into stainless steel charging bundles fitted with carbon steel endcaps for dissolution. The mass of Fe which may be dissolved during each dissolution is estimated by equation 1 .

$$
\left(\left(2 \frac{\text { cans }}{\text { well }}\right)\left(300 \frac{\mathrm{g} \mathrm{Fe}}{\text { can }}\right)+\left(400 \frac{\mathrm{g} \mathrm{Fe}}{\text { endcap }}\right)\left(1 \frac{\text { endcap }}{\text { well }}\right)\right)(10 \text { wells })=10,000 \mathrm{~g} \mathrm{Fe}
$$

Based on the minimum volume of the $6.1 \mathrm{D}$ dissolver (5250 L), the maximum concentration of iron in the dissolver solution will be $1.9 \mathrm{~g} / \mathrm{L}$.

\subsection{Objectives}

The purpose of the experimental work described in this report was two-fold. Initially a series of screening experiments was performed to measure the dissolution rate of Pu metal as functions of the $\mathrm{HNO}_{3}, \mathrm{KF}$, and $\mathrm{Gd}$ or B concentrations. The objective of the screening tests was to propose optimized conditions for subsequent flowsheet demonstration tests. Based on the rate measurements, this study found that optimal dissolution conditions in solutions containing 0.5-1.0 g/L Gd occurred in 8-10 $\mathrm{M} \mathrm{HNO}_{3}$ with 0.04-0.05 M KF at 112 to $116{ }^{\circ} \mathrm{C}$ (boiling). The testing also showed that solutions containing 8-10 $\mathrm{M} \mathrm{HNO}_{3}, 0.1-0.2 \mathrm{M} \mathrm{KF}$, and 1-2 $\mathrm{g} / \mathrm{L} \mathrm{B}$ achieved acceptable dissolution rates in the same temperature range. To confirm that conditions identified by the dissolution rate measurements for solutions containing Gd or B can be used to dissolve $\mathrm{Pu}$ metal up to $6.75 \mathrm{~g} / \mathrm{L}$ in the presence of $\mathrm{Fe}$, demonstration experiments were performed using concentrations in the optimal ranges. In two of the demonstration experiments using $\mathrm{Gd}$ and in one experiment using $\mathrm{B}$, the offgas generation during the dissolution was measured and samples were analyzed for $\mathrm{H}_{2}$. The experimental methods used to perform the dissolution rate measurements and flowsheet demonstrations and a discussion of the results are presented in the following sections.

\subsection{Experimental Procedure}

\subsection{Dissolution Rate Measurements}

A series of screening dissolution experiments was completed to compare the dissolution rates of $\mathrm{Pu}$ metal as a function of solution concentration. The Pu metal samples were cut from coupons of $\mathrm{Pu}$ metal received from the FB-Line vault in March 1999; their origin is unknown. The samples were fabricated from $\delta$-phase metal. A picture of the initial coupons is shown in Figure 2-1. 
Smaller coupons of metal were cut from initial coupons. The pieces for dissolution were then weighed to within $0.001 \mathrm{~g}$ and the physical dimensions measured to within $0.040 \mathrm{~cm}$ (1/64 in).
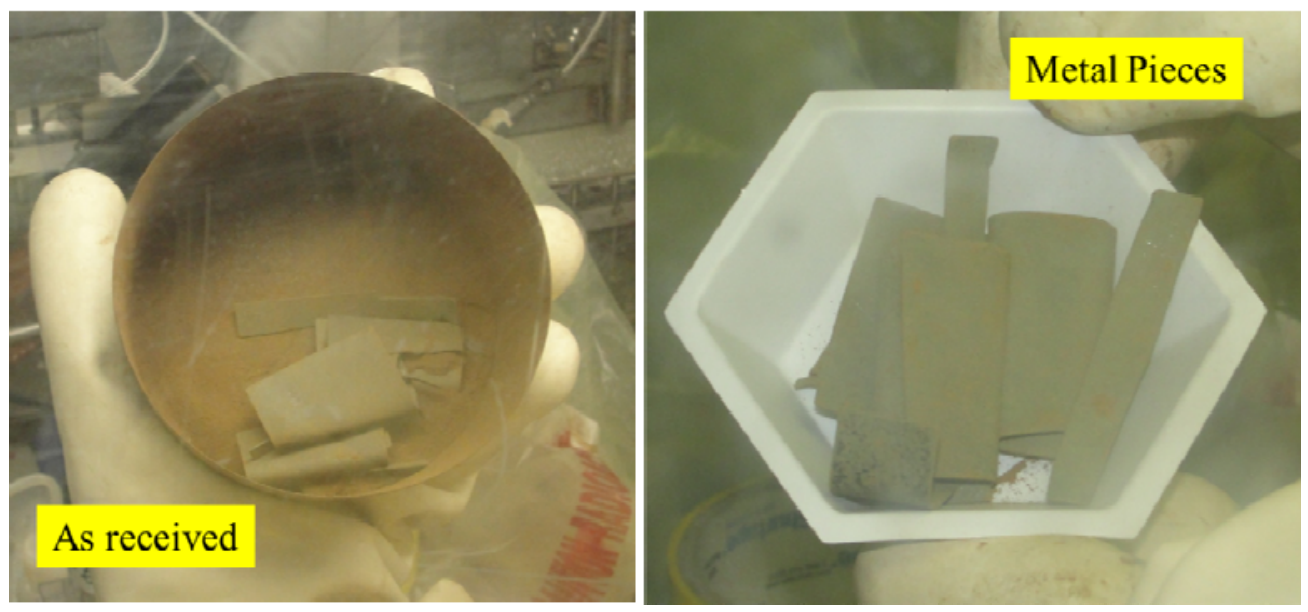

Figure 2-1. Pu Metal Coupons - Source Material for Test Samples

The dissolution test vessel was fabricated from borosilicate glass by the SRNL Glass Shop (as shown in Figure 2-2). A 600-mL dissolution vessel with a loose-fitting cover was placed on a hot plate-stirrer. A thermocouple was inserted into the side port of the dissolution pot; the thermocouple was used to measure and control the temperature of the dissolver solution. A condenser was inserted into the port on the top of the lid and clamped to the lid. The lid is designed to be filled with water to facilitate condensation of acid vapors in the dissolver head space. The condenser provides additional surface area for vapor condensation. A second thermocouple was fed down through the condenser into the dissolver solution before the beginning of each test to verify the operation of the control thermocouple; the thermocouples were removed before the start of the test. A Teflon ${ }^{\mathrm{TM}}$ sample holder was placed in the dissolution vessel. A small stir bar was placed in the dissolution vessel to be used for solution equilibration during heating; stirring was turned off during the measurement of dissolution rates.

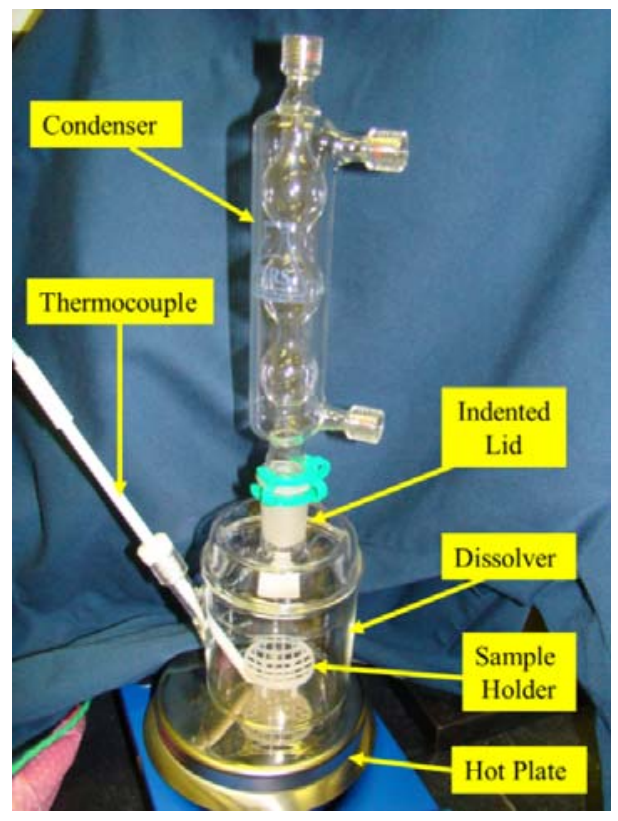

Figure 2-2. Dissolution Test Apparatus 
A list of test solutions used in the screening experiments is provided in Table 2-1. Each test was performed in a similar manner with a nominal solution volume of $200 \mathrm{~mL}$. The solution was added to the dissolution vessel and covered. Water was poured into the indented area of the lid. Neither air nor liquid flow was provided to the condenser. The solution was heated to $100{ }^{\circ} \mathrm{C}$. Once at temperature, the Pu metal sample was weighed. The cover of the dissolution vessel was removed, the sample placed on the sample holder, a timer started, and the cover put back on top of the dissolver.

Table 2-1. Test Conditions for Dissolution Rate Screening Studies at $100{ }^{\circ} \mathrm{C}$

\begin{tabular}{||c|c|c|c|c||}
\hline Test No. & $\mathrm{HNO}_{3}$ & $\mathrm{KF}$ & $\mathrm{Gd}$ & $\mathrm{B}$ \\
\hline & $(\mathrm{M})$ & $(\mathrm{M})$ & $(\mathrm{g} / \mathrm{L})$ & $(\mathrm{g} / \mathrm{L})$ \\
\hline $1 \mathrm{G}$ & 8 & 0.03 & 0.5 & 0 \\
\hline $2 \mathrm{G}$ & 8 & 0.05 & 0.5 & 0 \\
\hline 3G & 8 & 0.07 & 1 & 0 \\
\hline $4 \mathrm{G}$ & 10 & 0.015 & 0.5 & 0 \\
\hline $5 \mathrm{G}$ & 10 & 0.03 & 0.5 & 0 \\
\hline 6G & 10 & 0.05 & 1 & 0 \\
\hline $7 \mathrm{G}$ & 10 & 0.07 & 0.5 & 0 \\
\hline 8G* & 10 & 0.05 & 1 & 0 \\
\hline 9G* & 10 & 0.03 & 0.5 & 0 \\
\hline $1 \mathrm{~B}$ & 8 & 0.1 & 0 & 1 \\
\hline 2B & 10 & 0.1 & 0 & 1 \\
\hline 3B & 10 & 0.2 & 0 & 1 \\
\hline 4B* & 10 & 0.2 & 0 & 1 \\
\hline 5B & 8 & 0.2 & 0 & 2 \\
\hline 6B & 10 & 0.1 & 0 & 2 \\
\hline 7B & 10 & 0.2 & 0 & 2 \\
\hline 8B* & 10 & 0.2 & 0 & 2 \\
\hline * Tests conducted at $112{ }^{\circ} \mathrm{C}$ instead of $100^{\circ} \mathrm{C}$ \\
\hline
\end{tabular}

A picture of a sample during dissolution is shown in Figure 2-3. After a pre-determined time, the cover of the dissolver was removed, the sample was removed from the holder, and the timer stopped. The Pu metal sample was rinsed with $0.1 \mathrm{M} \mathrm{HNO}_{3}$, dried with a lint-free wipe, dried further by blowing dry argon gas across it, and weighed. The cover was placed back onto the dissolver. The dissolver solution was inspected for the presence of a residue. No residues were observed following any of the tests.

For each dissolver solution shown in Table 2-1, three separate dissolution rates were measured sequentially in the same dissolver solution to assess dissolution rate as a function of $\mathrm{Pu}$ concentration. At the end of testing for each dissolver solution, the solution was cooled and placed in a polyethylene bottle. The bottle was inspected periodically over the next few days for the formation of a precipitate. No precipitates were visible at ambient temperature $\left(\sim 20-22{ }^{\circ} \mathrm{C}\right)$ after storing the dissolver solutions for a few days. 


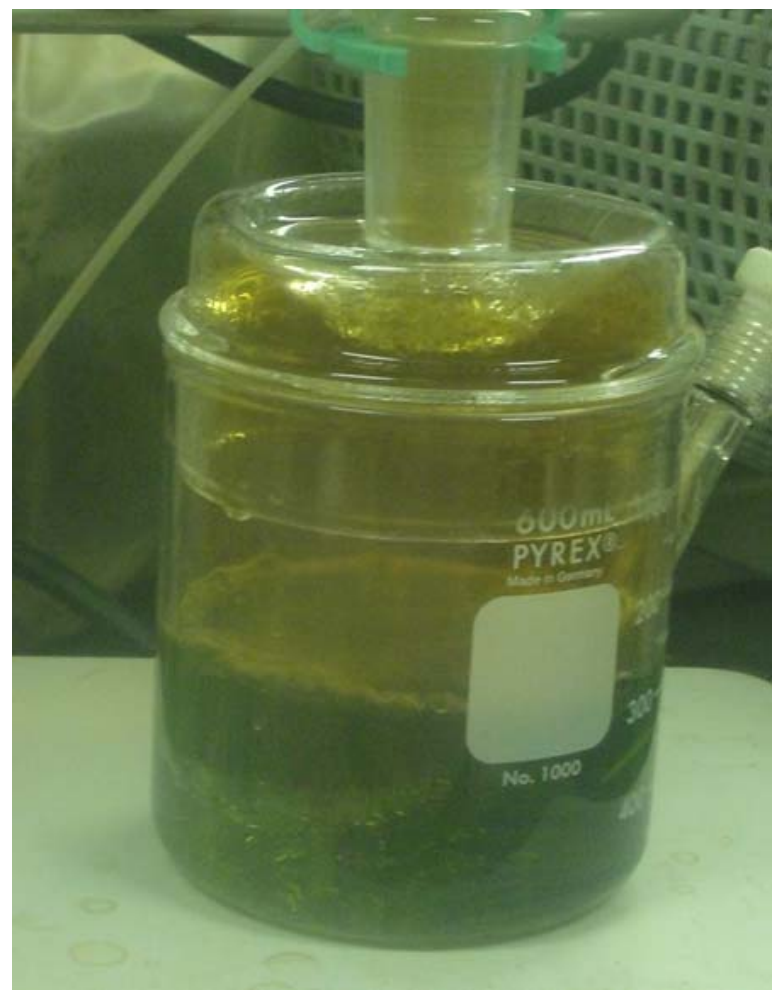

Figure 2-3. Dissolution of a Plutonium Metal Sample- Test 8G

\subsection{Low-Temperature Dissolution}

Using the apparatus in Figure 2-2, two dissolutions were performed (one each at $20{ }^{\circ} \mathrm{C}$ and $35^{\circ} \mathrm{C}$ ) in $250 \mathrm{~mL}$ of $10 \mathrm{M} \mathrm{HNO}_{3}$ containing $0.05 \mathrm{M} \mathrm{KF}$, and $0.5 \mathrm{~g} / \mathrm{L} \mathrm{Gd}$. The purpose of the test was to determine whether a boundary layer of dissolved Pu would form around the metal being dissolved. The $\mathrm{Pu}$ metal sample from Tests $1 \mathrm{~B}, 2 \mathrm{~B}$, and $3 \mathrm{~B}$ (surface area $\sim 8.31 \mathrm{~cm}^{2}$ ) was dissolved in both tests.

In the first test, the sample was dissolved without stirring in the dissolver solution at ambient temperature $\left(20{ }^{\circ} \mathrm{C}\right)$ for $65 \mathrm{~min}$. The initial and final sample weights were measured. Observations were made of gas generation at the metal surface and solution colors. The resulting dissolver solution was stirred and heated to $35^{\circ} \mathrm{C}$. The stirring was turned off and the sample was added to the dissolver solution for $45 \mathrm{~min}$. The initial and final sample weights were measured. Observations were made of gas generation at the metal surface and solution colors.

\subsection{Flowsheet Demonstrations}

\subsubsection{Test Conditions}

Five experiments were performed to demonstrate the dissolution of Pu metal in the presence of Fe and Gd or B using conditions identified during the dissolution rate measurements. Three of the experiments were performed using Gd as the neutron poison and two were performed using $\mathrm{B}$. A summary of the targeted test conditions used for each demonstration experiment is provided in Table 2-2. 
Table 2-2. Test Conditions for Pu Metal Dissolution Experiments

\begin{tabular}{|c|c|c|c|c|c|c|c||}
\hline Experiment & $\mathrm{HNO}_{3}$ & $\mathrm{KF}$ & $\mathrm{Gd}$ & $\mathrm{B}$ & $\mathrm{Fe}$ & Volume & Temperature \\
\hline & $(\mathrm{M})$ & $(\mathrm{M})$ & $(\mathrm{g} / \mathrm{L})$ & $(\mathrm{g} / \mathrm{L})$ & $(\mathrm{g} / \mathrm{L})$ & $(\mathrm{mL})$ & $\left({ }^{\circ} \mathrm{C}\right)$ \\
\hline $\mathrm{Pu} 1^{(1)}$ & 11 & 0.06 & 0.4 & & 0.3 & 575 & 100 \\
\hline $\mathrm{Pu} 2$ & 10 & 0.03 & 0.5 & & 1.9 & 500 & 100 \\
\hline $\mathrm{Pu} 3$ & 10 & 0.05 & 1.0 & & 1.9 & 546 & 100 \\
\hline $\mathrm{Pu} 4$ & 10 & 0.10 & & 1.0 & 1.9 & 550 & 100 \\
\hline $\mathrm{Pu} 5$ & 10 & 0.05 & & 1.0 & 1.9 & 550 & 100 \\
\hline
\end{tabular}

(1) estimated composition

The dissolving solution used for Experiment Pu1 was not prepared correctly; therefore, the experiment was repeated using the correct solution composition in Experiment Pu3. Since the conditions for the Pu1 dissolution were not representative of the desired flowsheet, only a brief discussion of the results is presented in Appendix A.

\subsubsection{Preparation of Pu Metal}

The Pu metal used in the flowsheet demonstration experiments was cut from the same coupons as used in the screening experiments to measure dissolution rates (Figure 2-1). To prepare metal for the demonstration experiments, the metal coupon was initially flattened and cut into pieces with masses which ranged between 3.5 and $4.1 \mathrm{~g}$. A mass in this range was selected to generate approximately $6.75 \mathrm{~g} / \mathrm{L} \mathrm{Pu}$ when dissolved in 500-600 $\mathrm{mL}$ of solution. The mass and dimensions of the metal pieces used in the demonstration experiments are provided in Table 2-3. The dimensions of the metal pieces were measured using a micrometer. The thickness was difficult to measure due to the irregular surface of the metal pieces; therefore a thickness of $0.8 \mathrm{~mm}$ was established based on the average of multiple measurements. Using this thickness, the calculated density of the metal pieces was $12-13 \mathrm{~g} / \mathrm{cm}^{3}$.

Table 2-3. Mass and Dimensions of Pu Metal Used in Flowsheet Demonstration Experiments

\begin{tabular}{||c|c|c|c|c|c|c||}
\hline \hline Experiment & Mass & Length & Short & Long & Width & Thickness $^{(1)}$ \\
\hline & & & Side & Side & & \\
\hline & $(\mathrm{g})$ & $(\mathrm{mm})$ & $(\mathrm{mm})$ & $(\mathrm{mm})$ & $(\mathrm{mm})$ & $(\mathrm{mm})$ \\
\hline Pu1 & 4.1183 & 29.08 & & & 14.63 & 0.8 \\
\hline Pu2 & 3.5060 & 33.60 & & & 10.29 & 0.8 \\
\hline Pu3 & 3.8676 & 24.66 & & & 15.02 & 0.8 \\
\hline Pu4 & 3.8286 & 29.92 & 8.96 & 15.48 & & 0.8 \\
\hline Pu5 & 3.8330 & 44.49 & & & 8.42 & 0.8 \\
\hline
\end{tabular}

(1) average

\subsubsection{Pu Metal Dissolving System}

The dissolution vessel and offgas collection system were fabricated from borosilicate glass by the SRNL Glass Shop. A photograph of the equipment is shown in Figure 2-4. The dissolving vessel was fabricated from a 500-mL round-bottom flask. Penetrations were added for a condenser, sample port, thermocouple, and nitrogen gas $\left(\mathrm{N}_{2}\right)$ purge and the bottom was flattened slightly to facilitate heating and agitation using a hot plate/stirrer (with magnetic stir bar). The temperature was controlled using an external thermocouple monitored by the hot plate. The offgas from the dissolution exited through the air-cooled condenser. When the offgas was collected during Experiments Pu2, Pu3, and Pu5, Viton ${ }^{\circledR}$ tubing was used to connect a $40-\mathrm{mL}$ sample bulb and a 
1-L Tedlar ${ }^{\circledR}$ gas-collection bag (Figure 2-5) to the condenser. The sample bulb was connected to the tubing using quick-disconnect fittings which allowed easy replacement of the bulb during dissolution. The bulbs were fabricated using glass stopcocks at both ends to prevent leakage following removal from the dissolving system. The Tedlar ${ }^{\circledR}$ bag was placed in a water-filled vessel with a graduated cylinder incorporated into the top which allowed measurement of the gas volume by water displacement.

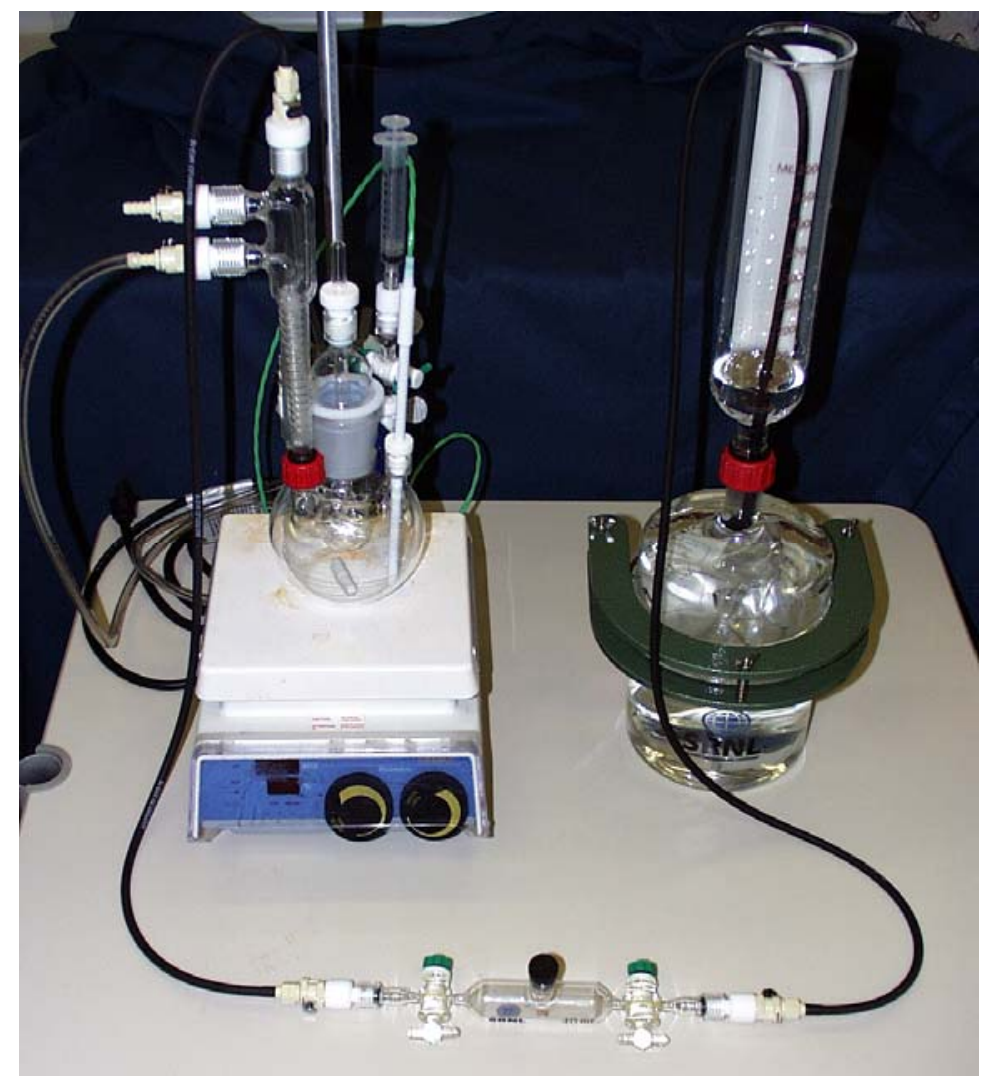

Figure 2-4. Pu Metal Dissolving System

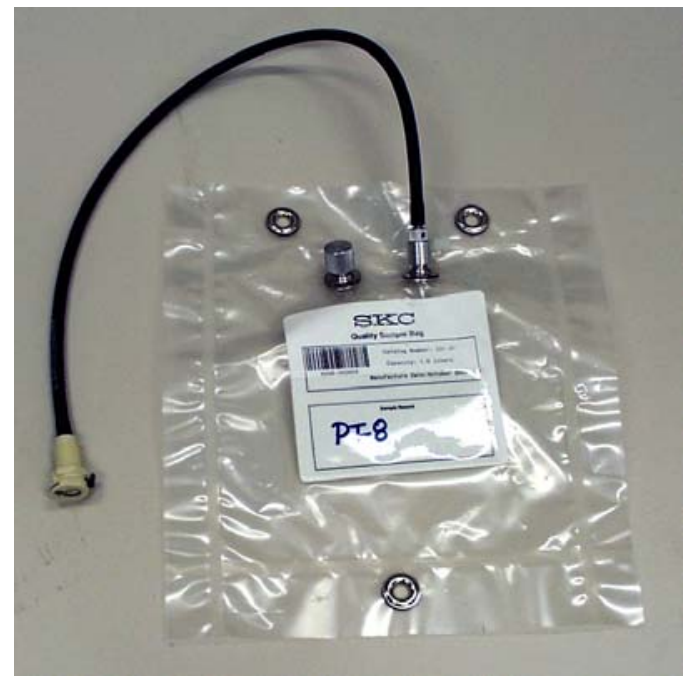

Figure 2-5. Tedlar $^{\circledR}$ Gas-collection Bag 
To perform the dissolution test, the Pu metal was initially placed in a perforated glass basket. The basket was suspended in the dissolver by a glass rod held in place by a compression fitting. The compression fitting allowed adjustment of the basket height. The Pu metal was held above the dissolving solution until the desired temperature was reached. When the offgas was collected during Experiments Pu2, Pu3, and Pu5, air was initially purged from the dissolver and condenser using $\mathrm{N}_{2}$. A penetration in the dissolver (obscured by the condenser in Figure 2-4) equipped with a quick-disconnect fitting was provided to attach the $\mathrm{N}_{2}$ supply line. A slow $\mathrm{N}_{2}$ purge (estimated at $50-100 \mathrm{~mL} / \mathrm{min}$ ) was maintained through the dissolver for at least $30 \mathrm{~min}$ prior to heating the solution. Once the $\mathrm{N}_{2}$ purge was complete, a gas sample bulb and the Tedlar ${ }^{\circledR}$ bag were attached to the dissolving system. Agitation was then started at $400 \mathrm{rpm}$ and the hot plate set point was adjusted to $100{ }^{\circ} \mathrm{C}$. During Experiments Pu1 and Pu4, the offgas was not collected which allowed verification of the solution temperature measured by the hot plate thermocouple using a calibrated thermometer. The hot plate maintained the solution temperature at $100 \pm 3{ }^{\circ} \mathrm{C}$. When the desired temperature was reached, the glass basket containing the Pu metal was lowered into the solution and the volume of water in the graduated cylinder was recorded. The volume of water displaced by the offgas was recorded periodically during the experiment.

Samples of the solution were taken at either 10 or 15 min intervals during the experiments. At each sample time, the volume of water in the graduated cylinder was recorded (if applicable). A $10 \mathrm{~mL}$ disposable syringe was attached to the sample port (see Figure 2-4) using a Luer lock fitting. The stopcock was opened and a 2-mL aliquot of solution was removed from the dissolver. After closing the stopcock, the syringe was removed and the liquid was transferred to a sample vial for subsequent analysis. The volume of water in the graduated cylinder was recorded again to determine if sampling changed the volume of offgas collected. Following sampling, it was necessary to inject $5 \mathrm{~mL}$ of either air or $\mathrm{N}_{2}$ into the sample port to clear solution from the sampler dip tube in preparation for the next sample. Nitrogen was used to clear the dip tube when offgas from the dissolution was collected. The volume of water in the graduated cylinder was recorded before and after clearing the dip tube to determine if the gas injection changed the volume of offgas collected. The solution samples were analyzed for ${ }^{239} \mathrm{Pu}$ and ${ }^{241} \mathrm{Am}$ by gamma pulse height analysis (GPHA) and the gas samples were analyzed by gas chromatography. Samples of the solution following the dissolutions were also analyzed for metals by inductively-coupled plasma emission spectroscopy (ICPES) and free acid by titration.

Following each flowsheet demonstration experiment, a small aliquot of the dissolving solution was examined by UV-visible spectroscopy to determine the oxidation state of the Pu. The UVvisible spectra were recorded using an AvaSpec-2048TEC thermo-electric cooled fiber optic spectrometer. The presence of $\mathrm{Pu}(\mathrm{VI})$ in the dissolving solutions` was evaluated using the characteristic $\mathrm{Pu}(\mathrm{VI})$ peak at $831 \mathrm{~nm}$ in nitrate solutions.

\subsection{Results and Discussion}

\subsection{Dissolution Rate Measurements}

The times and weight measurements used to determine the Pu dissolution rates in the screening experiments are listed in Table 3-1. The calculated dissolution rates are shown in Table 3-2. 
Table 3-1. Dissolution Time and Weight Measurements

\begin{tabular}{|c|c|c|c|c|c|c|c|c|}
\hline Test No. & Mass 1 & Time 1 & Mass 2 & Time 2 & Mass 3 & Time 3 & Mass 4 & Pu \\
\hline & $(\mathrm{g})$ & $(\mathrm{min})$ & $(\mathrm{g})$ & $(\mathrm{min})$ & $(\mathrm{g})$ & $(\mathrm{min})$ & $(\mathrm{g})$ & $(\mathrm{g} / \mathrm{L})$ \\
\hline 1G & 2.948 & 5 & 2.787 & 7 & 2.572 & 12 & 2.286 & 3.3 \\
\hline 2G & 2.288 & 7 & 1.858 & 5 & 1.564 & 6 & 1.255 & 5.2 \\
\hline 3G & 2.959 & 4 & 2.661 & 3 & 2.416 & 4 & 2.164 & 4.0 \\
\hline 4G & 5.001 & 20 & 4.801 & 30 & 4.433 & 30 & 4.188 & 4.1 \\
\hline 5G & 4.439 & 5 & 4.235 & 7 & 3.991 & 10 & 3.693 & 3.7 \\
\hline 6G & 4.188 & 7 & 3.607 & 5 & 3.272 & 5 & 2.952 & 6.2 \\
\hline 7G & 3.993 & 4 & 3.496 & 3 & 3.275 & 4 & 2.959 & 5.2 \\
\hline 8G & 3.688 & 3 & 3.3 & 3 & 2.949 & 4 & 2.542 & 5.7 \\
\hline 9G & 2.544 & 5 & 2.213 & 7 & 1.809 & 10 & 1.388 & 5.8 \\
\hline 1B & 4.170 & 3.5 & 3.750 & 3 & 3.407 & 3 & 3.119 & 6.0 \\
\hline 2B & 3.119 & 3 & 2.776 & 3 & 2.458 & 3 & 2.132 & 4.9 \\
\hline 3B & 2.126 & 1.5 & 1.839 & 1.5 & 1.558 & 1.6 & 1.276 & 4.3 \\
\hline 4B & 2.160 & 1 & 1.843 & 1 & 1.534 & 1.8 & 1.031 & 5.6 \\
\hline 5B & 4.332 & 2 & 3.967 & 2 & 3.577 & 2 & 3.21 & 5.6 \\
\hline 6B & 3.210 & 3 & 2.926 & 3.2 & 2.626 & 3 & 2.348 & 4.3 \\
\hline 7B & 2.348 & 1.5 & 2.090 & 1.5 & 1.827 & 1.5 & 1.565 & 3.9 \\
\hline 8B & 1.565 & 1 & 1.298 & 1 & 1.026 & 1 & 0.758 & 4.0 \\
\hline
\end{tabular}

The surface area was calculated from measurements of the width and length of the piece. Because the pieces were thin $(\sim 0.8 \mathrm{~mm})$, the calculated surface area disregards the surface area along the edge of the sample. The data for the Gd flowsheet are displayed on Figure 3-1 at 0.015-0.05 M $\mathrm{KF}$. The data in $10 \mathrm{M} \mathrm{HNO}_{3}$ for the $1 \mathrm{~g} / \mathrm{L}$ and $2 \mathrm{~g} / \mathrm{L}$ B flowsheets are displayed on Figure 3-2.

Table 3-2. Dissolution Rate Calculations

\begin{tabular}{||c|c|c|c|c|c|c|}
\hline Test No. & Rate 1 & Ave. Pu 1 & Rate 2 & Ave. Pu 2 & Rate 3 & Ave. Pu 3 \\
\hline & $\left(\mathrm{mg} / \mathrm{min}^{\left.-\mathrm{cm}^{2}\right)}\right.$ & $(\mathrm{g} / \mathrm{L})$ & $\left(\mathrm{mg} / \mathrm{min}^{\left.-\mathrm{cm}^{2}\right)}\right.$ & $(\mathrm{g} / \mathrm{L})$ & $\left(\mathrm{mg} / \mathrm{min}-\mathrm{cm}^{2}\right)$ & $(\mathrm{g} / \mathrm{L})$ \\
\hline 1G & 3.61 & 0.4 & 3.44 & 1.3 & 2.67 & 2.6 \\
\hline 2G & 6.89 & 1.1 & 6.59 & 2.9 & 5.77 & 4.4 \\
\hline 3G & 9.49 & 0.7 & 10.40 & 2.1 & 8.03 & 3.3 \\
\hline 4G & 1.12 & 0.5 & 1.38 & 1.9 & 0.92 & 3.5 \\
\hline 5G & 5.35 & 0.5 & 4.57 & 1.6 & 3.91 & 3.0 \\
\hline 6G & 9.30 & 1.5 & 7.51 & 3.7 & 7.17 & 5.4 \\
\hline $7 \mathrm{G}$ & 15.8 & 1.2 & 9.38 & 3.0 & 10.1 & 4.4 \\
\hline 8G* & 17.0 & 1.0 & 15.4 & 2.8 & 13.4 & 4.7 \\
\hline 9G* & 8.7 & 0.8 & 7.6 & 2.7 & 5.5 & 4.7 \\
\hline 1B & 14.4 & 1.8 & 13.8 & 3.7 & 11.6 & 5.3 \\
\hline 2B & 13.8 & 0.9 & 12.8 & 2.5 & 13.1 & 4.1 \\
\hline 3B & 23.0 & 0.7 & 22.5 & 2.1 & 21.2 & 3.5 \\
\hline 4B* & 35.5 & 0.8 & 34.6 & 2.4 & 32.2 & 4.4 \\
\hline 5B & 22.7 & 0.9 & 24.3 & 2.8 & 22.9 & 4.7 \\
\hline 6B & 11.8 & 0.7 & 11.8 & 2.2 & 11.5 & 3.6 \\
\hline 7B & 21.4 & 0.6 & 21.8 & 1.9 & 21.8 & 3.3 \\
\hline 8B* & 33.3 & 0.7 & 33.9 & 2.0 & 33.4 & 3.4 \\
\hline * Tests conducted at $112{ }^{\circ} \mathrm{C}$ instead of $100{ }^{\circ} \mathrm{C}$ & & \\
\hline
\end{tabular}


SRNL-STI-2012-00043

Revision 0

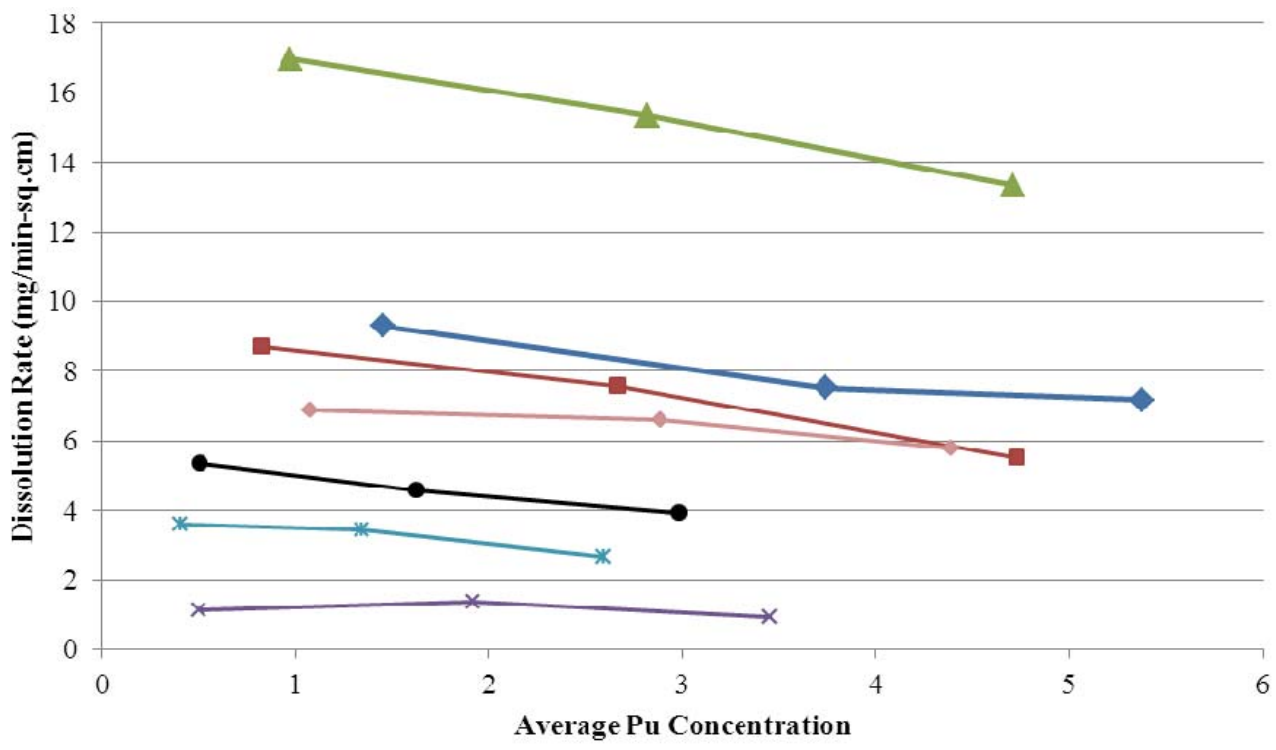

$\multimap 10 \mathrm{M} \mathrm{H}+, 0.015 \mathrm{M} \mathrm{KF}, 0.5 \mathrm{~g} / \mathrm{L} \mathrm{Gd}, 100^{\circ} \mathrm{C} \leadsto 8 \mathrm{M} \mathrm{H}+, 0.03 \mathrm{M} \mathrm{KF}, 0.5 \mathrm{~g} / \mathrm{L} \mathrm{Gd}, 100^{\circ} \mathrm{C}$

$\rightarrow 10 \mathrm{M} \mathrm{H}^{+}, 0.03 \mathrm{M} \mathrm{KF}, 0.5 \mathrm{~g} / \mathrm{L} \mathrm{Gd}, 100^{\circ} \mathrm{C} \quad-10 \mathrm{M} \mathrm{H}+, 0.03 \mathrm{M} \mathrm{KF}, 0.5 \mathrm{~g} / \mathrm{L} \mathrm{Gd}, 112{ }^{\circ} \mathrm{C}$ $\multimap 8 \mathrm{M} \mathrm{H}^{+}, 0.05 \mathrm{M} \mathrm{KF}, 0.5 \mathrm{~g} / \mathrm{L} \mathrm{Gd}, 100^{\circ} \mathrm{C} \quad \longrightarrow 10 \mathrm{M} \mathrm{H}+, 0.05 \mathrm{M} \mathrm{KF}, 1 \mathrm{~g} / \mathrm{L} \mathrm{Gd}, 100^{\circ} \mathrm{C}$ $-10 \mathrm{M} \mathrm{HNO} 3,0.05 \mathrm{M} \mathrm{KF}, 1 \mathrm{~g} / \mathrm{L} \mathrm{Gd}, 112^{\circ} \mathrm{C}$

Figure 3-1. Effect of $\mathrm{HNO}_{3}, \mathrm{KF}$, and Temperature on Dissolution Rate for 0.5-1.0 g/L Gd

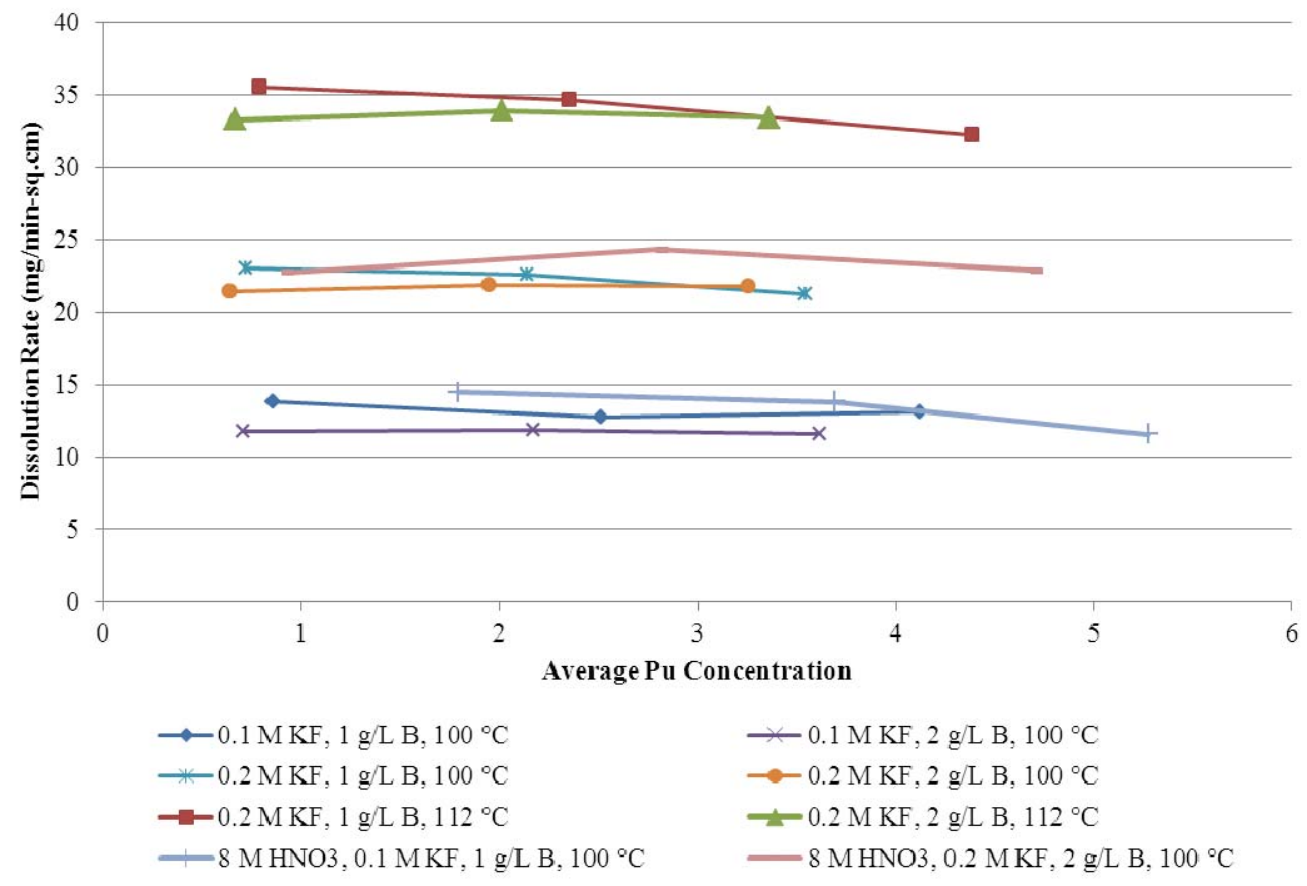

Figure 3-2. Effect of B, KF, and Temperature on Dissolution Rate for 1-2 g/L B in $10 \mathrm{M} \mathrm{HNO}_{3}$ 
As discussed earlier, a desired target dissolution rate of $20 \mathrm{mg} / \mathrm{min}-\mathrm{cm}^{2}$ was selected to correspond to the dissolution of a "standard" button in $24 \mathrm{~h}$. For a dissolution flowsheet using Gd, the largest dissolution rates at $112{ }^{\circ} \mathrm{C}$ for $10 \mathrm{M} \mathrm{HNO}_{3}$ and $0.03-0.05 \mathrm{M} \mathrm{KF}$ do not meet the desired target; a KF concentration of $0.07 \mathrm{M}$ is the upper limit for avoiding precipitation at low $\mathrm{Pu}$ concentrations. The average dissolution rate is $\sim 7 \mathrm{mg} / \mathrm{min}-\mathrm{cm}^{2}$ for $10 \mathrm{M} \mathrm{HNO}_{3}, 0.03 \mathrm{M} \mathrm{KF}$, and 0.5-1.0 g/L Gd at $112{ }^{\circ} \mathrm{C}$ for dissolution from 0 to $6 \mathrm{~g} / \mathrm{L} \mathrm{Pu}$. This corresponds to a 72-hour dissolution time for a "standard" button (see Figure 1-1). If the KF in the solution is increased to $0.05 \mathrm{M}$, the average dissolution rate increases to $\sim 15 \mathrm{mg} / \mathrm{min}-\mathrm{cm}^{2}$, or $\sim 36$ hours to dissolve a "standard" button.

Testing with B instead of Gd yielded flowsheets that were able to dissolve at $20 \mathrm{mg} / \mathrm{min}-\mathrm{cm}^{2}$. The precipitation issue associated with $\mathrm{Gd}$ does not exist for $\mathrm{B}$ at the concentrations tested $(1-2 \mathrm{~g} / \mathrm{L}$ B). The solubility of boric acid $\left(\mathrm{H}_{3} \mathrm{BO}_{3}\right)$ in $10 \mathrm{M} \mathrm{HNO}_{3}$ (at $25{ }^{\circ} \mathrm{C}$ ) is approximately $2.75 \mathrm{~g} / \mathrm{L}$; therefore, exceeding the $\mathrm{H}_{3} \mathrm{BO}_{3}$ solubility limit is not an issue.[12] Higher KF concentrations can be considered for the dissolution, although corrosion control issues and the precipitation of $\mathrm{B}$ as $\mathrm{KBF}_{4}$ must also be taken into account. The precipitation of $\mathrm{B}$ as $\mathrm{KBF}_{4}$ has been observed in 9.214.1 $\mathrm{M} \mathrm{HNO}_{3}$ solutions containing 0.22 M KF when the total fluoride was increased above $0.3 \mathrm{M}$.[13] Experiments allowed measurement of dissolution rates at $0.1 \mathrm{M}$ and $0.2 \mathrm{M} \mathrm{KF}$ at $100{ }^{\circ} \mathrm{C}$ and $112{ }^{\circ} \mathrm{C}$. The data are displayed in Figure 3-3 and listed in Table 3-2. In $10 \mathrm{M} \mathrm{HNO}_{3}$ and $0.2 \mathrm{M} \mathrm{KF}$, the dissolution rate was $32-35 \mathrm{mg} / \mathrm{min}-\mathrm{cm}^{2}$ at $112{ }^{\circ} \mathrm{C}$. Although no data were collected for $0.1 \mathrm{M} \mathrm{KF}$ at $112{ }^{\circ} \mathrm{C}$, a nominal increase of $\sim 50 \%$ was observed at $0.03 \mathrm{M} \mathrm{KF}$ (Tests 5G/9G) and 0.2 M KF (Tests 3B/4B and 7B/8B). If a similar increase in rate occurs for $0.1 \mathrm{M} \mathrm{KF}$ (Tests 1B, 2B, and 6B), dissolution rates of $\sim 18-20 \mathrm{mg} / \mathrm{min}^{-\mathrm{cm}^{2}}$ will be achieved.

It is interesting to note that the data show little difference between $1 \mathrm{~g} / \mathrm{L} \mathrm{B}$ and $2 \mathrm{~g} / \mathrm{L} \mathrm{B}$, although the $2 \mathrm{~g} / \mathrm{L}$ data are all slightly below the $1 \mathrm{~g} / \mathrm{L}$ data. Also, there is little difference between $8 \mathrm{M}$ and $10 \mathrm{M} \mathrm{HNO}_{3}$ at the same KF concentrations. For Gd, there was a small but significant difference between $8 \mathrm{M}$ and $10 \mathrm{M} \mathrm{HNO}_{3}$ data (Figure 3-1). In light of the small impact of $\mathrm{B}$ concentration on dissolution rate, plots of $\mathrm{Gd}$ and $\mathrm{B}$ data were produced for $8 \mathrm{M} \mathrm{HNO}_{3}$ (Figure 3-3) and $10 \mathrm{M} \mathrm{HNO}_{3}$ (Figure 3-4) to determine if there was a trend independent of the poison used.

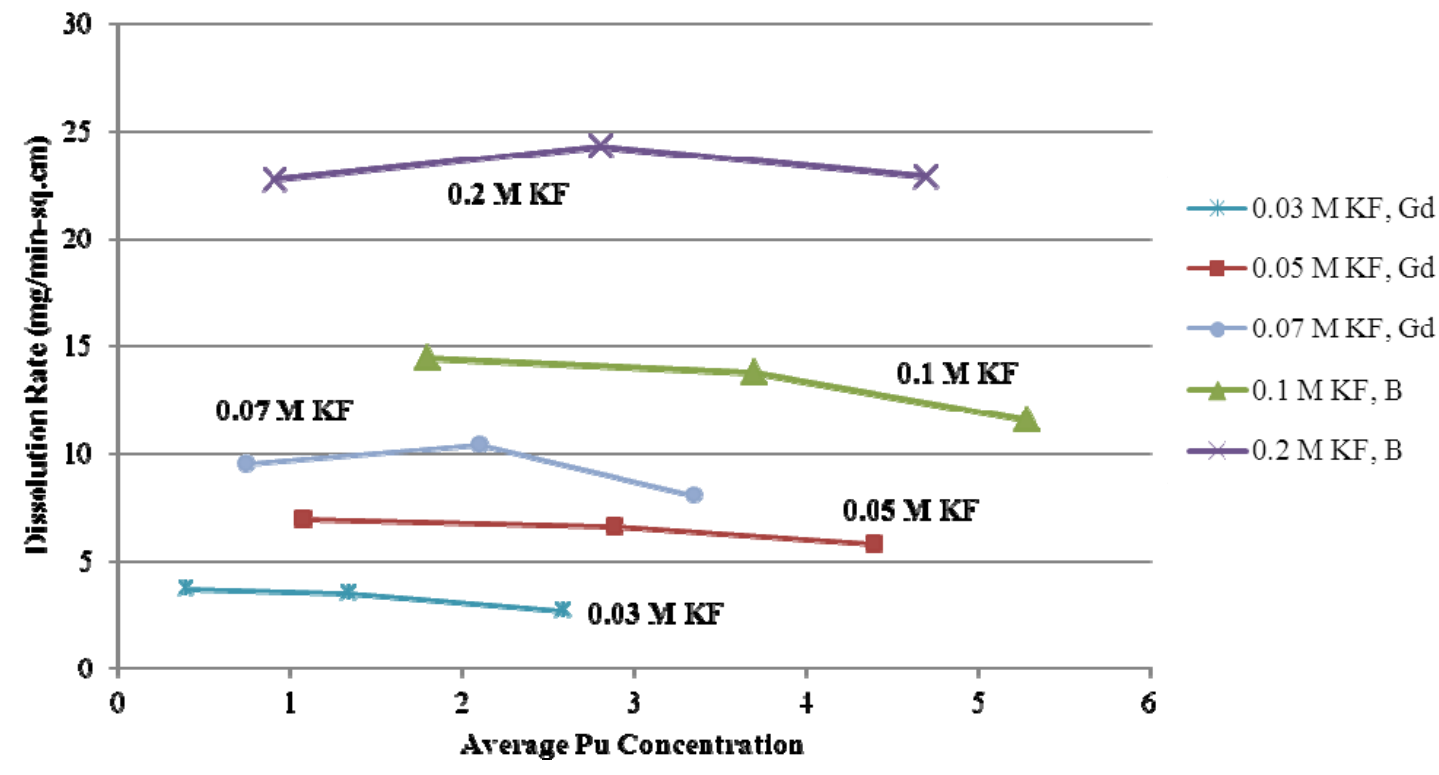

Figure 3-3. Effect of $\mathrm{KF}$ at $8 \mathrm{M} \mathrm{HNO}_{3}$ and $100{ }^{\circ} \mathrm{C}$ 
SRNL-STI-2012-00043

Revision 0

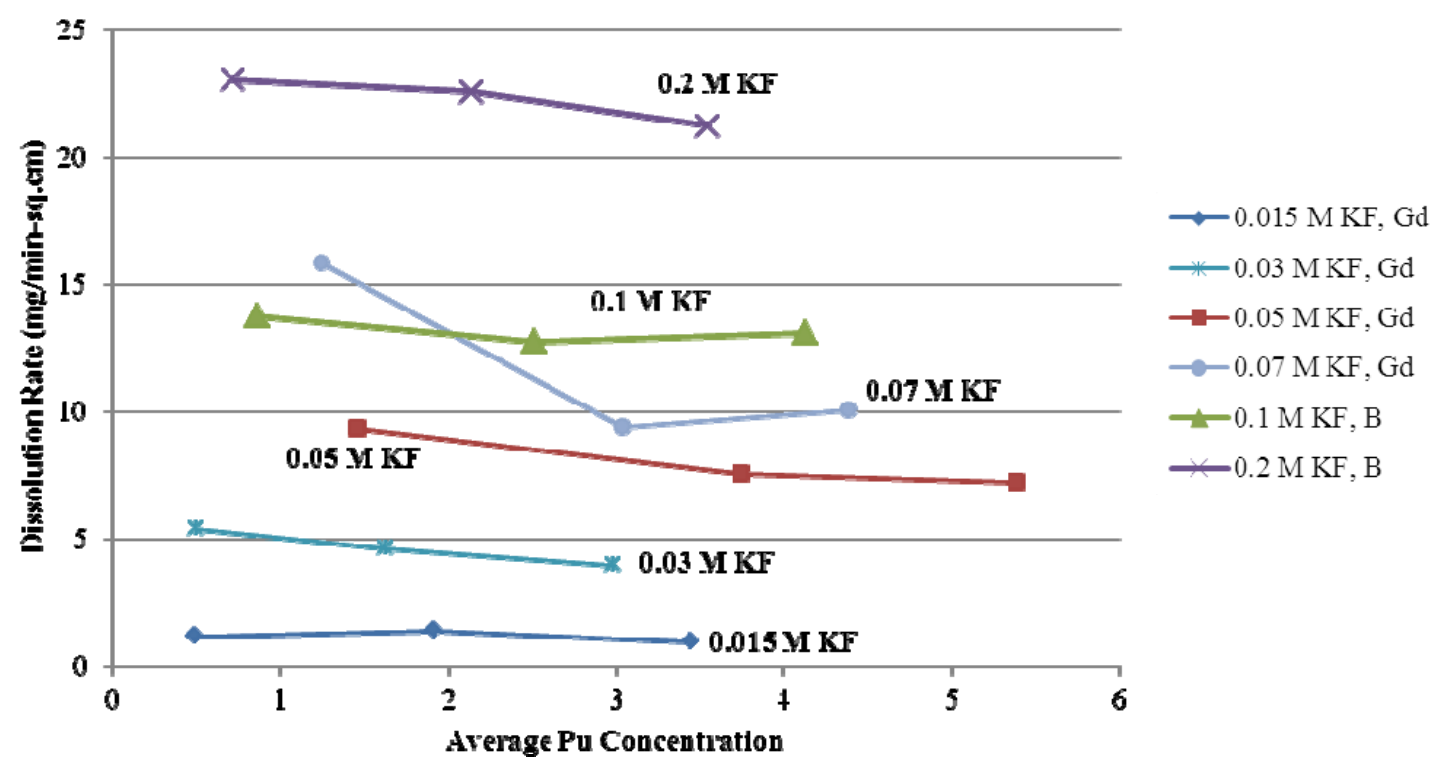

Figure 3-4. Effect of $\mathrm{KF}$ at $10 \mathrm{M} \mathrm{HNO}_{3}$ and $100{ }^{\circ} \mathrm{C}$

The data in Figure 3-3 and Figure 3-4 suggest that dissolution rate at a given $\mathrm{HNO}_{3}$ concentration is dependent upon KF concentration, and that poison has minimal impact. Other than the data for $10 \mathrm{M} \mathrm{HNO}_{3}$ and $0.07 \mathrm{M} \mathrm{KF}$ (Figure 3-4), the dissolution rate data in both figures show a steady increase as the KF concentration increases with little dependence on poison concentration. These results suggest that dissolution rates in 0.03-0.07 M KF and 1-2 g/L B will be similar to those observed for 0.03-0.07 M KF and 0.5-1.0 g/L Gd.

The increases in dissolution rates as a function of $\mathrm{HNO}_{3}$ concentration and temperature are indicative of the trends expected for the dissolution of $\mathrm{PuO}_{2}$. $\mathrm{Pu}$ metal dissolution studies by Miner et al. at 1-5 $\mathrm{M} \mathrm{HNO}_{3}, 0.01-0.13 \mathrm{M} \mathrm{HF}$, and 23-69 ${ }^{\circ} \mathrm{C}$ showed that Pu metal dissolution rates were optimal in $3 \mathrm{M} \mathrm{HNO}_{3}$ and decreased with increasing $\mathrm{HNO}_{3}$ concentration beyond $\sim 3 \mathrm{M} \mathrm{HNO}_{3}$.[5] The study also showed that dissolution rate decreased with increasing temperature in $0.13 \mathrm{M} \mathrm{HF}$ but increased with increasing temperature at $0.01 \mathrm{M}$ and $0.07 \mathrm{M} \mathrm{HF}$. It should be noted that the conclusions from Miner's work are based on calculated curves derived from measured values. For the 13 data points where both measured and calculated rates are reported, the average difference was $7.2 \%$, the maximum difference was $16.7 \%$, and 11 of the 13 calculated values exhibited differences less than $10.0 \%$.

The differences in behavior between Miner's work and this study suggest that different dissolution mechanisms are occurring. The results obtained by Miner suggest that the primary mechanism for Pu metal dissolution is direct dissolution of the metal impeded by the presence of $\mathrm{PuO}_{2}$.[5] Therefore, conditions which result in the increased formation of $\mathrm{PuO}_{2}$ (elevated $\mathrm{HNO}_{3}$ concentrations and temperatures) suppress $\mathrm{Pu}$ metal dissolution. However, Miner did not test at temperatures sufficiently high $\left(\sim 90^{\circ} \mathrm{C}\right)$ for $\mathrm{PuO}_{2}$ dissolution to become a dominant dissolution mechanism.[4] In the current studies, highly-oxidative conditions were used such that the formation of $\mathrm{PuO}_{2}$ at the surface of the metal was rapid. However, the use of high $\mathrm{HNO}_{3}$ concentrations and temperatures $\left(100-112^{\circ} \mathrm{C}\right)$ also enabled more-rapid dissolution of the $\mathrm{PuO}_{2}$ from the surface of the metal. Consequently, those things which accelerate $\mathrm{PuO}_{2}$ dissolution rates (increasing $\mathrm{HNO}_{3}, \mathrm{KF}$, and temperature) yielded higher $\mathrm{Pu}$ "metal” dissolution rates. 
To estimate a total dissolution time for $\mathrm{Pu}$ metal pieces of varying thicknesses, assuming dissolution from 0 to $6 \mathrm{~g} / \mathrm{L} \mathrm{Pu}$, linear-penetration rates were calculated from the dissolution rate when the dissolver solution was at $3 \mathrm{~g} / \mathrm{L} \mathrm{Pu}$. The calculations assume that the metal is immersed and dissolved at both sides of the item. The calculations are tabulated in Table 3-3 for $\alpha$-phase $\mathrm{Pu}$ $\left(\rho=19.8 \mathrm{~g} / \mathrm{cm}^{3}\right)$ and $\delta$-phase Pu $\left(\rho=15.9 \mathrm{~g} / \mathrm{cm}^{3}\right)$ metals. A nominal 2250-g FB-Line button of $\alpha$-phase $\mathrm{Pu}$ metal is $1.90 \mathrm{~cm}$ thick.[14] Because the actual boiling point of $10 \mathrm{M} \mathrm{HNO}_{3}$ is $\sim 116^{\circ} \mathrm{C}$, actual linear penetration rates should be higher than those listed in Table 3-3.

Table 3-3. Calculated Linear Penetration Rates at $112{ }^{\circ} \mathrm{C}$ for 0 to $6 \mathrm{~g} / \mathrm{L} \mathrm{Pu}$

\begin{tabular}{|c|c|c|c|c|c||}
\hline $\mathrm{HNO}_{3}$ & $\mathrm{KF}$ & $\mathrm{Gd}$ & $\mathrm{B}$ & $\alpha \mathrm{Pu}$ & $\delta \mathrm{Pu}$ \\
\hline$(\mathrm{M})$ & $(\mathrm{M})$ & $(\mathrm{g} / \mathrm{L})$ & $(\mathrm{g} / \mathrm{L})$ & $(\mathrm{cm} / \mathrm{h})$ & $(\mathrm{cm} / \mathrm{h})$ \\
\hline 10 & 0.03 & 0.5 & 0 & 0.042 & 0.052 \\
\hline 10 & 0.05 & 1 & 0 & 0.091 & 0.113 \\
\hline 10 & 0.2 & 0 & 1 & 0.203 & 0.253 \\
\hline 10 & 0.2 & 0 & 2 & 0.203 & 0.253 \\
\hline
\end{tabular}

\subsection{Low-Temperature Dissolution}

In the test at $20^{\circ} \mathrm{C}$ for $65 \mathrm{~min}$, the initial sample weight was $1.236 \mathrm{~g}$ and the final weight was 1.066 g. No visible gas generation was observed during dissolution. As the sample dissolved, the more-dense Pu-bearing solution at the surface of the sample descended away from the metal sample to the bottom of the dissolution vessel. The dissolved Pu did not dissipate throughout the dissolver solution or form a boundary layer around the metal sample. This phenomenon is shown in Figure 3-5. This indicates that in the H-Canyon dissolver insert, the Pu will diffuse out of the insert into the bulk solution where it will disperse. After 65 min of dissolution, a small amount of residue was present underneath the sample (Figure 3-5) which was likely $\mathrm{PuO}_{2}$ from the surface of the metal coupon. The residue was not weighed.
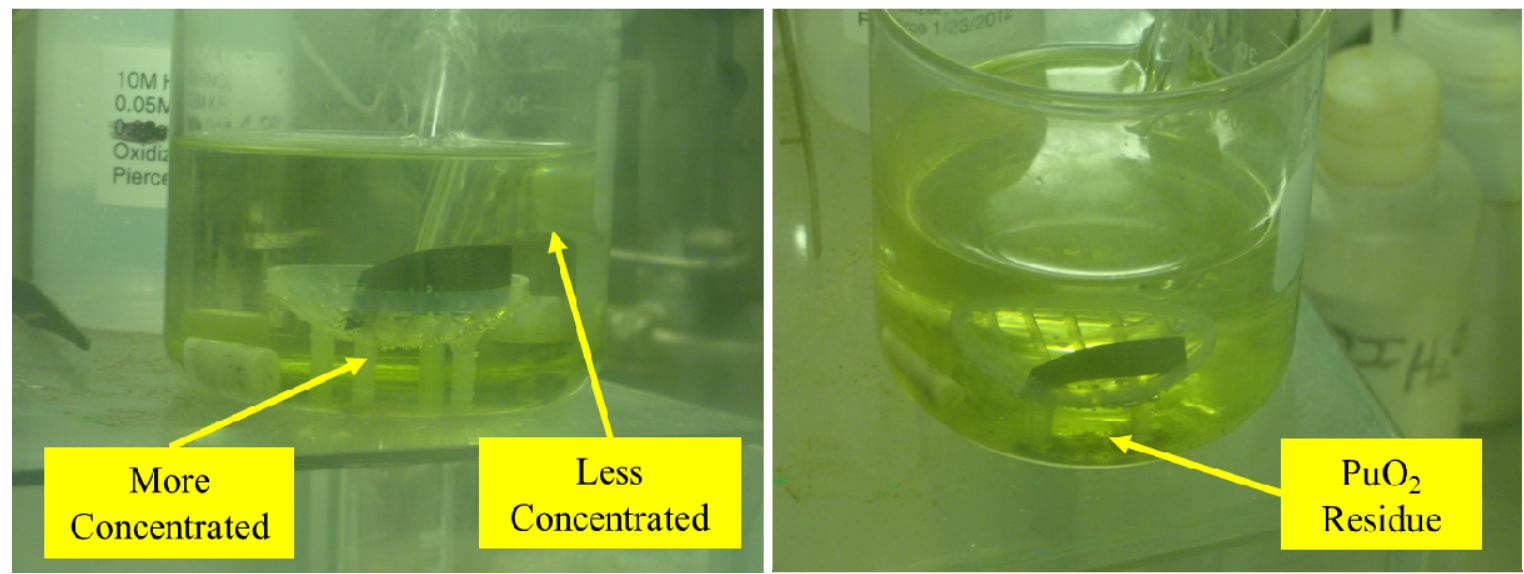

Figure 3-5. Pu Metal Dissolution at $20^{\circ} \mathrm{C}$

In the test at $35{ }^{\circ} \mathrm{C}$ for $45 \mathrm{~min}$, the initial sample weight was $1.066 \mathrm{~g}$ and the final weight was $0.842 \mathrm{~g}$. Similar to the test at $20^{\circ} \mathrm{C}$, no visible gas generation was observed at the surface of the metal during dissolution. However, a small amount of $\mathrm{NO}_{2}$ gas was observed above the dissolver solution. Unlike the test at $20^{\circ} \mathrm{C}$, as the sample dissolved, the Pu was dispersed throughout the solution, probably due to the thermal currents provided by the hot plate while maintaining the dissolver solution at $35{ }^{\circ} \mathrm{C}$ (Figure 3-6). A boundary layer did not form around the metal sample. The dispersion of $\mathrm{Pu}$ by thermal currents indicates that minimal mixing will be required to disperse dissolved $\mathrm{Pu}$ that descends away from the metal surface into the bulk dissolver solution. 
After 45 min of dissolution, a trace amount of residue (visually less than in the test at $20{ }^{\circ} \mathrm{C}$ ) was present underneath the sample. The residue was not weighed.

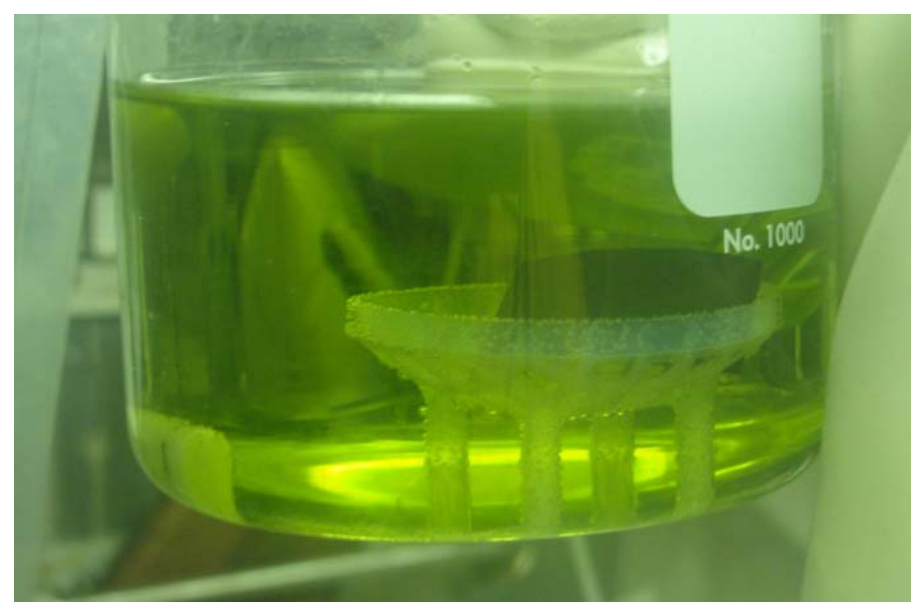

Figure 3-6. Pu Metal Dissolution at $35{ }^{\circ} \mathrm{C}$

\subsection{Flowsheet Demonstrations}

\subsubsection{General Observations}

Inspection of the Pu metal during the dissolution experiments was not possible without removing the glass basket from the dissolver. Almost immediately after the metal was lowered into the dissolving solution, brown nitrogen dioxide $\left(\mathrm{NO}_{2}\right)$ gas filled the dissolver. Termination of the experiments was either based on removing the glass basket to inspect the Pu metal (if the offgas was not collected) or the cessation of offgas generation. In each experiment, complete dissolution of the $\mathrm{Pu}$ metal was attained. No residues were observed in the solutions when they were removed from the dissolver or following 4-6 weeks of storage.

\subsubsection{Sample Analysis}

The GPHA for the samples generated during the $\mathrm{Pu}$ metal dissolutions are provided in Appendix B. Activities for both ${ }^{239} \mathrm{Pu}$ and ${ }^{241} \mathrm{Am}$ were measured. The ${ }^{239} \mathrm{Pu}$ activities were converted to total $\mathrm{Pu}$ values by assuming the metal coupons were weapons grade $\mathrm{Pu}$ containing 94 wt $\%{ }^{239} \mathrm{Pu}$. Before the concentrations were correlated with the dissolution time, they were corrected for the small change in volume which occurred due to the removal of samples and evaporation losses; although, a small concentrating effect would be expected in an H-Canyon dissolver due to evaporation. The final volume at the conclusion of the experiments decreased between 24 and $54 \mathrm{~mL}$. A small correction was also made for the amount of material removed in samples prior to completing the experiment. The mass of $\mathrm{Pu}$ removed in each $2 \mathrm{~mL}$ sample ranged between 1 and $15 \mathrm{mg}$. The magnitude of the corrections ranged from $<1$ to $7 \%$. The largest corrections were necessary for Experiment Pu2 which required $4.25 \mathrm{~h}$ to complete the dissolution. The procedure used to correct the concentration and the calculated values are provided in Appendix B.

The corrected $\mathrm{Pu}$ and $\mathrm{Am}$ concentrations as functions of the dissolution time are plotted in Figures 3-7 to 3-10 for Experiments Pu2, Pu3, Pu4, and Pu5, respectively. The error bars in the figures reflect the one sigma uncertainty in the GPHA (Tables B.2-B.5). The uncertainties associated with the volume measurements used to calculate the corrected actinide concentrations were found to be insignificant compared to the uncertainties in the radiochemical analyses. 


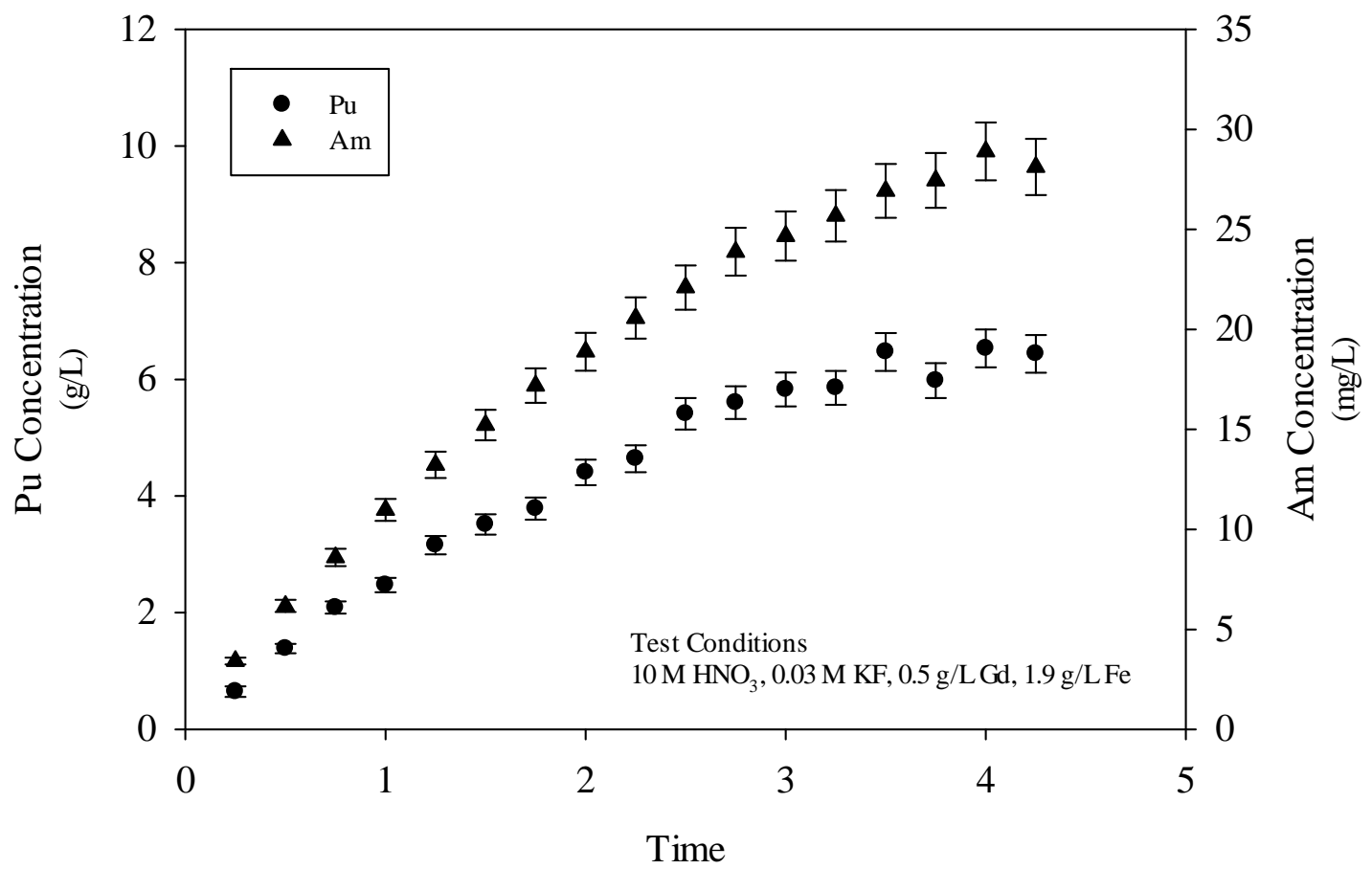

(h)

Figure 3-7. Corrected Actinide Concentrations in Experiment Pu2

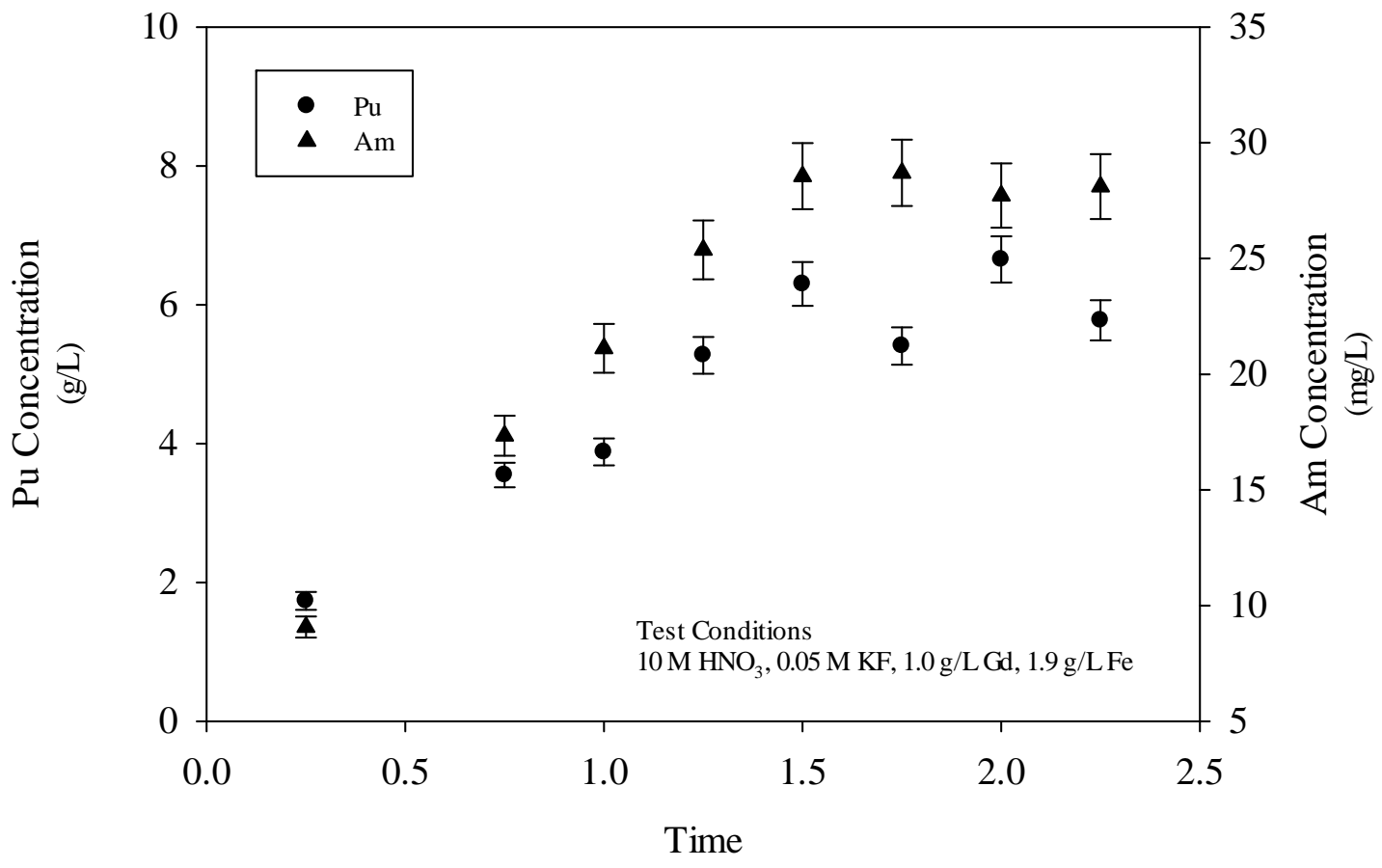

(h)

Figure 3-8. Corrected Actinide Concentrations in Experiment Pu3 


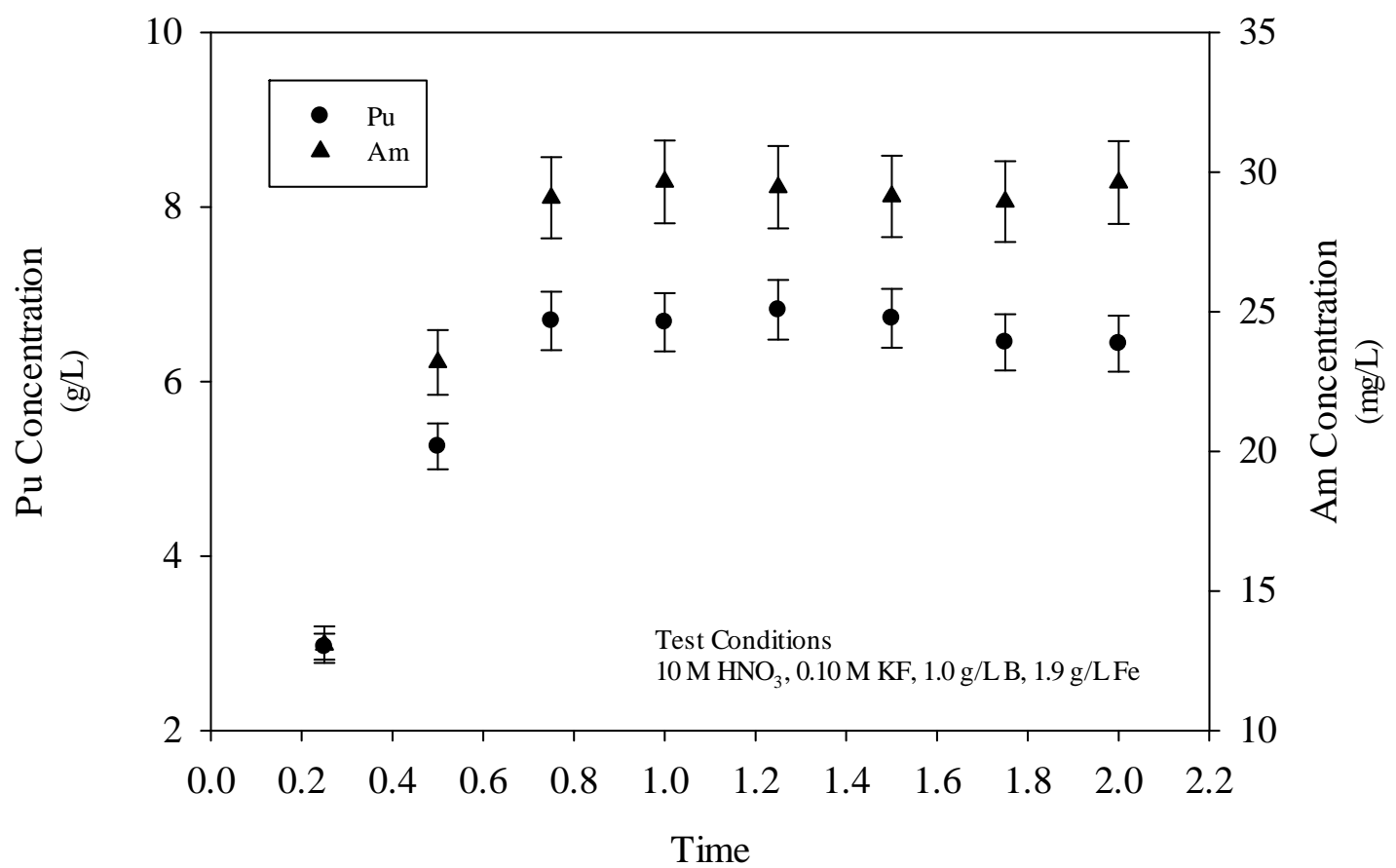

(h)

Figure 3-9. Corrected Actinide Concentrations in Experiment Pu4

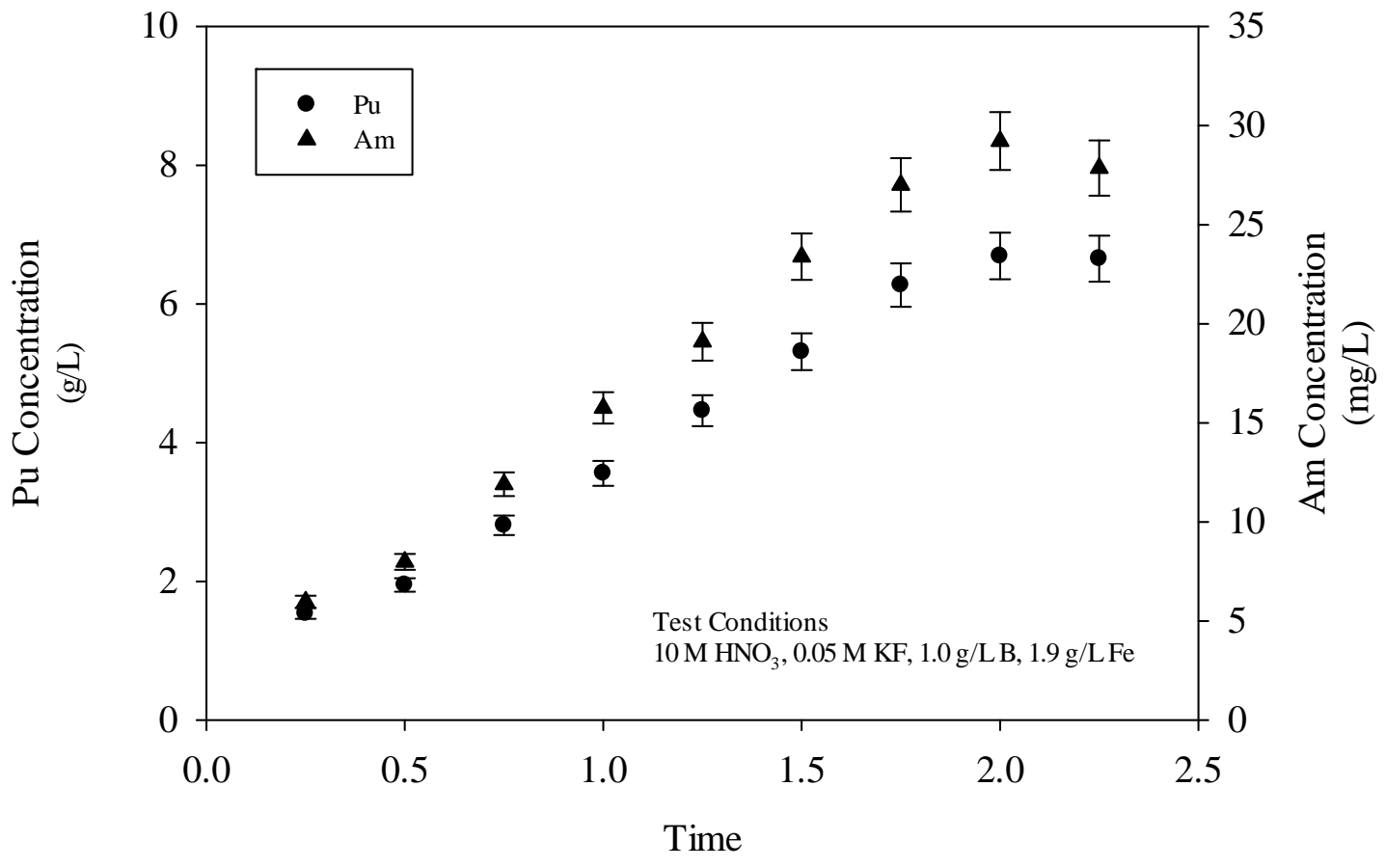

(h)

Figure 3-10. Corrected Actinide Concentrations in Experiment Pu5 
The Pu and Am concentrations (Figures 3-7 to 3-10) are consistent with the observation that complete dissolution was attained in each experiment. Each figure showed a steady increase in the actinide concentration with time which approached a constant value at the end of the experiment. Table 3-4 provides a comparison of the maximum corrected concentration (at the end of an experiment) to the concentration calculated from the mass of Pu metal and the volume of the dissolving solution used in the experiment. The uncertainties in the $\mathrm{Pu}$ concentrations calculated from the metal masses and initial volumes of solution were based on a $1 \%$ relative standard deviation in each of the measurements. The calculations are summarized in Appendix B.

Table 3-4. Comparison of Pu Concentrations Based on Corrected Value and Metal Mass

\begin{tabular}{||c|c|c|c||}
\hline Experiment & (Corrected) Pu & (Mass-based) Pu & Difference \\
\hline & Concentration & Concentration & \\
\hline & $(\mathrm{g} / \mathrm{L})$ & $(\mathrm{g} / \mathrm{L})$ & $(\%)$ \\
\hline $\mathrm{Pu} 2$ & $6.53 \pm 0.33$ & $7.08 \pm 0.10$ & -7.81 \\
\hline $\mathrm{Pu} 3$ & $6.65 \pm 0.33$ & $7.08 \pm 0.10$ & -6.11 \\
\hline $\mathrm{Pu} 4$ & $6.82 \pm 0.34$ & $6.96 \pm 0.10$ & -1.99 \\
\hline $\mathrm{Pu} 5$ & $6.69 \pm 0.33$ & $6.97 \pm 0.10$ & -3.99 \\
\hline
\end{tabular}

The Pu concentrations for each experiment show good agreement. In each case, the corrected concentration is biased low. This is likely due to the loss of $\mathrm{PuO}_{2}$ from the surface of the metal coupon during handling. Uncertainties in the radiochemical analyses and inaccuracies in the estimated volume losses during the experiments may have also contributed to the differences in the concentrations.

To calculate the amount of $\mathrm{Pu}$ and Am metal dissolved as a function of time, the estimated solution volume and the Pu and Am concentrations at each sample time were used to calculate the mass of $\mathrm{Pu}$ and $\mathrm{Am}$ in solution. The calculated mass was expressed as a percentage of the total mass dissolved based on the maximum mass of $\mathrm{Pu}$ and $\mathrm{Am}$ in solution at the end of the experiment. The calculations are summarized in Appendix B. Figures 3-11 to 3-14 show the mass of $\mathrm{Pu}$ and Am dissolved as a function of time for experiments Pu2, Pu3, Pu4, and Pu5, respectively. The error bars in the figures were calculated using the one sigma uncertainties in the GPHA (Tables B.2-B.5) and propagation of error techniques. The uncertainties associated with the volume measurements used to calculate the amounts of the metals dissolved were found to be insignificant compared to the uncertainties in the radiochemical analyses. The error analysis is summarized in Appendix B.

The percentages of $\mathrm{Pu}$ and Am dissolved during each experiment were very close in magnitude which indicates that the metals dissolved uniformly. The curves for each experiment were used to approximate the time required for complete dissolution of the metal coupons. The values are given in Table 3-5.

Table 3-5. Time Required for Complete Dissolution of Pu Metal Coupons

\begin{tabular}{||c|c|}
\hline Experiment & Dissolution Time \\
\hline & (h) \\
\hline Pu2 & 3.5 \\
\hline Pu3 & 2.0 \\
\hline Pu4 & 0.75 \\
\hline Pu5 & 2.0 \\
\hline
\end{tabular}




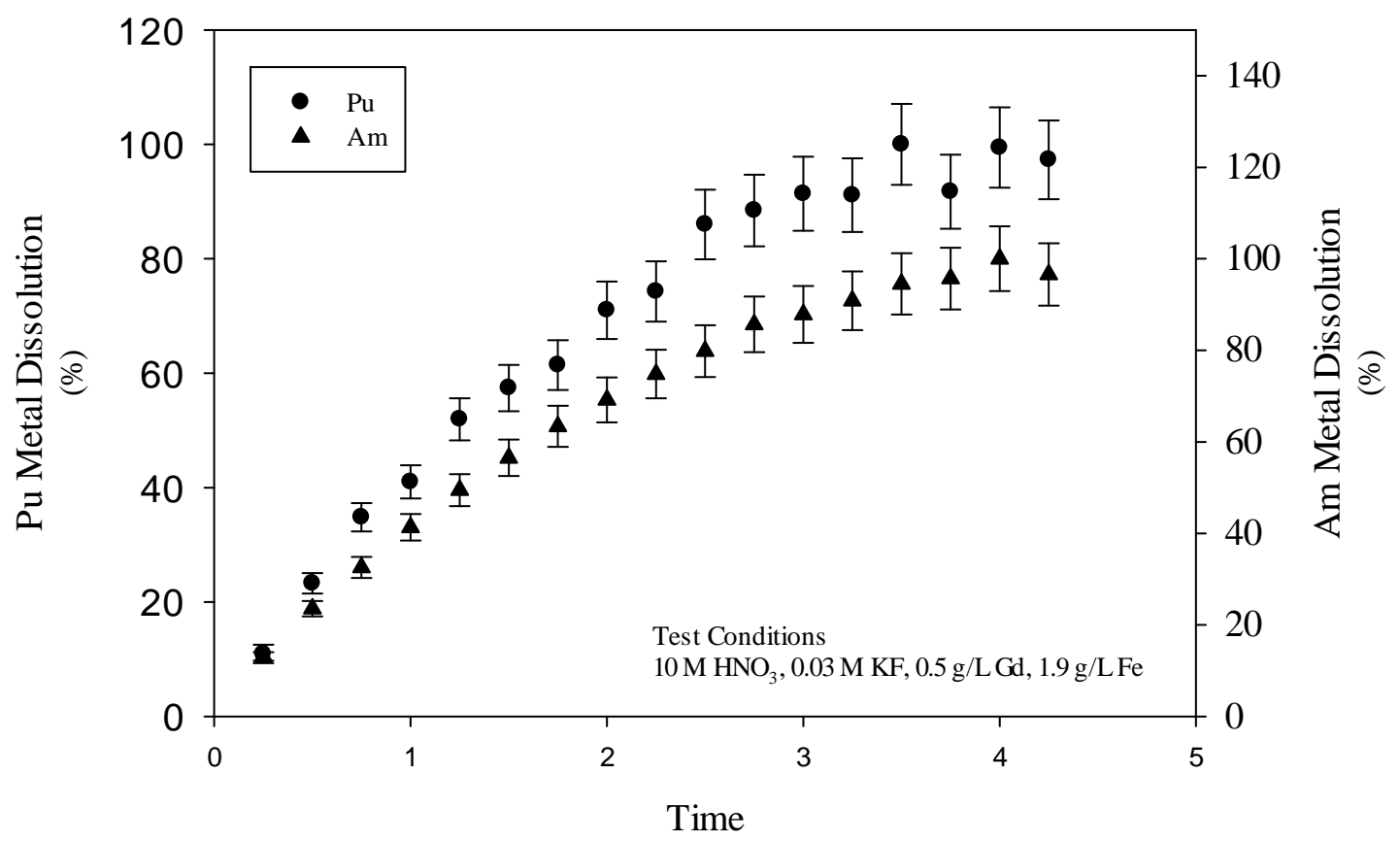

(h)

Figure 3-11. Actinide Metal Dissolution in Experiment Pu2

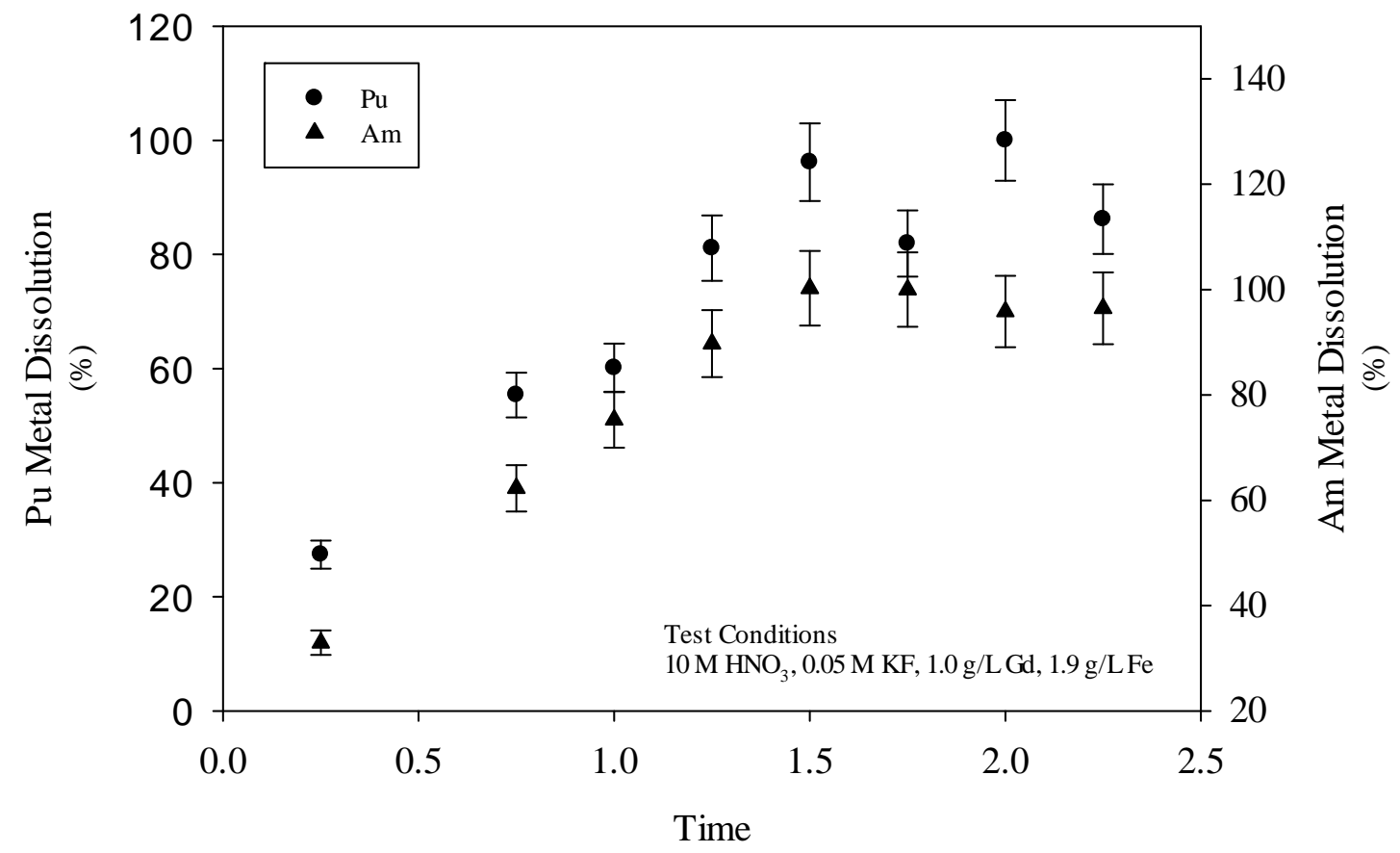

(h)

Figure 3-12. Actinide Metal Dissolution in Experiment Pu3 


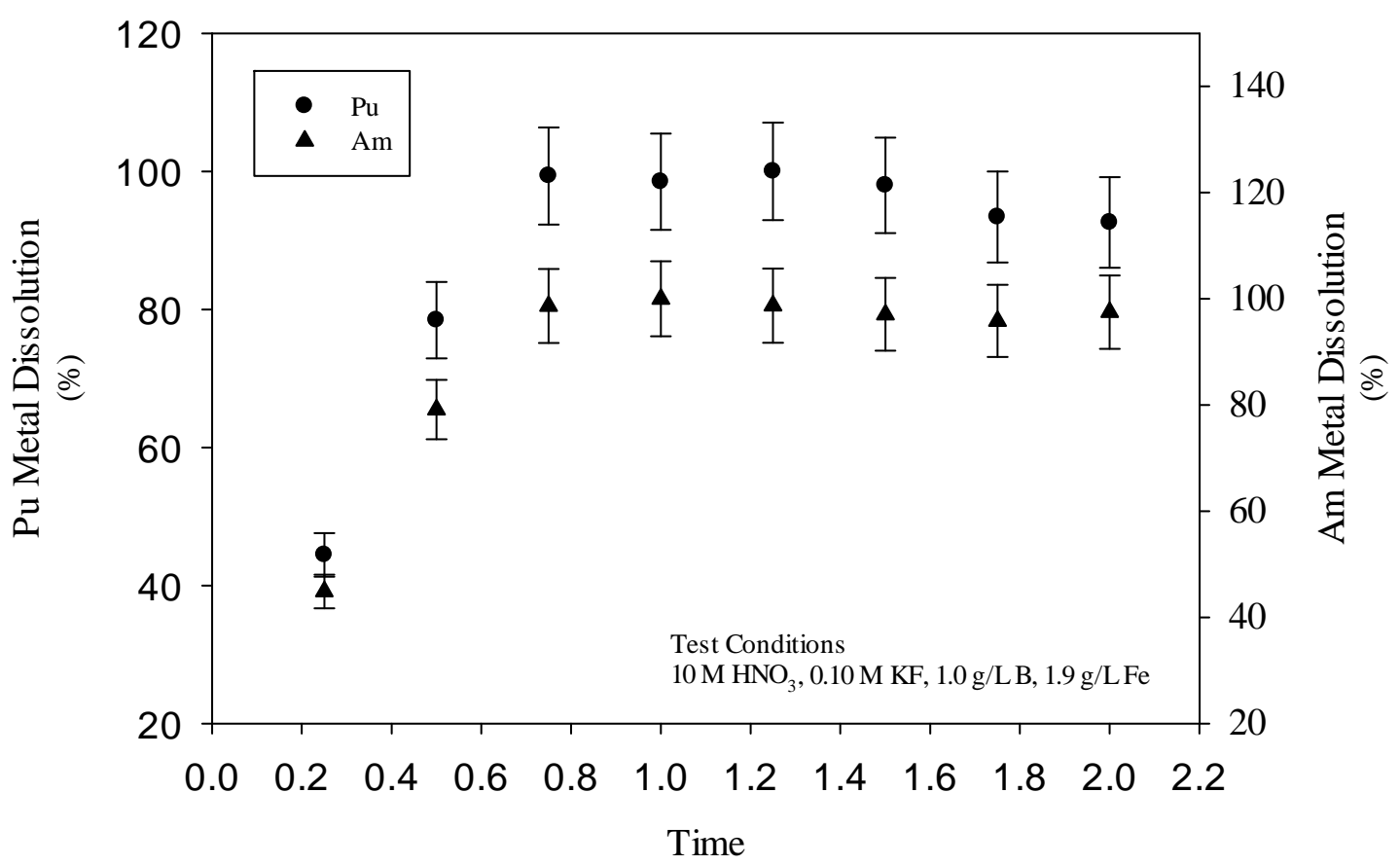

(h)

Figure 3-13. Actinide Metal Dissolution in Experiment Pu4

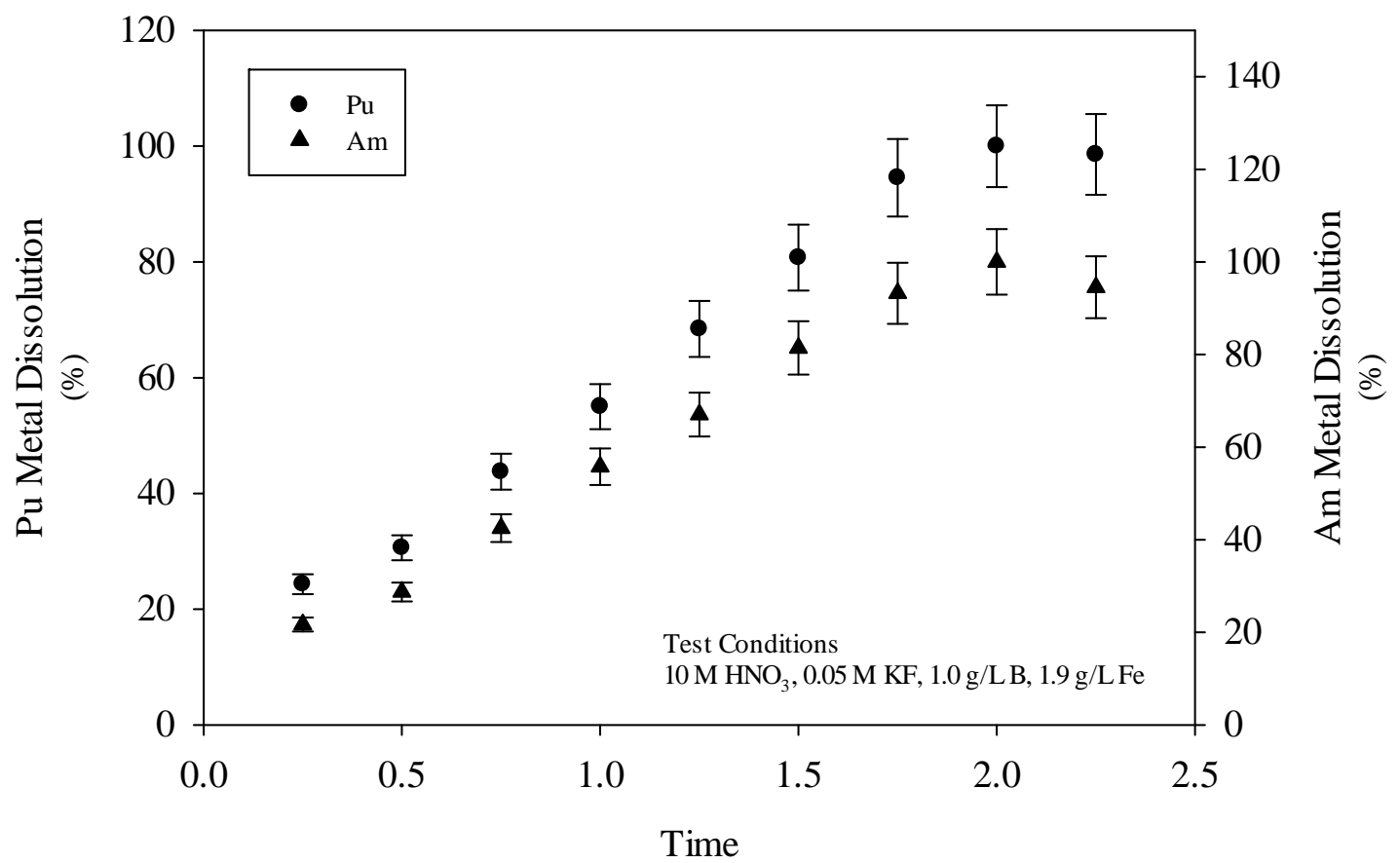

(h)

Figure 3-14. Actinide Metal Dissolution in Experiment Pu5 


\subsubsection{Initial Dissolution Rates}

The initial dissolution rate of the Pu metal coupons was estimated using the calculated mass of $\mathrm{Pu}$ dissolved during the early stage of the experiments and the surface area of the coupons. During this period, the surface area would be expected to remain reasonably constant due to the uniform dissolution of the metal. Calculation of the initial dissolution rates and the uncertainty analysis are summarized in Appendix B. In the uncertainty analysis, the variance in the surface area of the $\mathrm{Pu}$ metal coupons was based on a $10 \%$ relative standard deviation. The calculated values are compared with values measured during the experimental study in Table 3-6.

Table 3-6. Comparison of Pu Metal Dissolution Rates

\begin{tabular}{||c|c|c|c|c|c|c|c|}
\hline \hline Experiment & $\mathrm{HNO}_{3}$ & KF & Gd & B & Fe & Estimated & Measured \\
\hline & & & & & & Rate & Rate \\
\hline & $(\mathrm{M})$ & $(\mathrm{M})$ & $(\mathrm{g} / \mathrm{L})$ & $(\mathrm{g} / \mathrm{L})$ & $(\mathrm{g} / \mathrm{L})$ & $\left(\mathrm{mg} / \mathrm{min}-\mathrm{cm}^{2}\right)$ & $\left(\mathrm{mg} / \mathrm{min}^{-} \mathrm{cm}^{2}\right)$ \\
\hline Pu2 & 10 & 0.03 & 0.5 & & 1.9 & $3.51 \pm 0.7$ & 5.35 \\
\hline Pu3 & 10 & 0.05 & 1.0 & & 1.9 & $4.34 \pm 0.7$ & 9.30 \\
\hline Pu4 & 10 & 0.10 & & 1.0 & 1.9 & $11.3 \pm 1.9$ & 13.8 \\
\hline Pu5 & 10 & 0.05 & & 1.0 & 1.9 & $4.04 \pm 0.9$ & $(1)$ \\
\hline
\end{tabular}

(1)Dissolution rate was not measured at these conditions

The dissolution rates estimated using the data from the flowsheet demonstrations agree reasonably well with the measured rates with the exception of the experiment performed using $10 \mathrm{M} \mathrm{HNO}_{3}$ containing $0.05 \mathrm{M} \mathrm{KF}, 1.0 \mathrm{~g} / \mathrm{L} \mathrm{Gd}$, and $1.9 \mathrm{~g} / \mathrm{L}$ Fe (Experiment Pu3). The estimated and measured rates for these conditions differ by approximately a factor of two. No satisfactory explanation is apparent for the difference at this time. The dissolution rates measured with $0.05 \mathrm{M}$ $\mathrm{KF}$ in the solution (Experiments Pu3 and Pu5) appear consistent. The dissolution rates were approximately equal which was also inferred from the measured offgas generation rates (see section 3.2.4). Based on these data and the offgas generation rates, the presence of Gd or B in the dissolving solution has about the same effect on the dissolution rate.

\subsubsection{Offgas Generation}

The offgas generation rate during the dissolution of the Pu metal in Experiments Pu2, Pu3, and Pu5 was measured by water displacement. Samples of the offgas were also analyzed by gas chromatography. The presence of the Viton ${ }^{\circledR}$ tubing in the graduated cylinder increased the measured volume by a constant factor (1.37\%) equal to the ratio of the cross sectional area of the tubing compared to the cross sectional area of the cylinder. The volume correction due to the water pressure on the gas bag varied linearly with the amount of gas collected. The correction factors applied to the volume of offgas collected are provided in Appendix C.

The offgas volume measured during Experiments Pu2, Pu3, and Pu5 and the cumulative collection times are given in Table 3-7. Two offgas samples were taken during Experiments Pu2 and Pu5. Three samples were taken during Experiment Pu3, although little gas was generated during the collection of the third sample. The volumes of offgas produced during each sample period are also provided in the table. 
Table 3-7. Offgas Volumes Collected during Pu Dissolution Experiments

\begin{tabular}{||c|c|c|c|c|c|c|c|c||}
\hline \hline Exp. & \multicolumn{2}{|c|}{ Sample 1 } & \multicolumn{2}{c|}{ Sample 2 } & \multicolumn{2}{c|}{ Sample 3 } & Total & Total \\
\hline & Time & Volume & Time & Volume & Time & Volume & Time & Volume \\
\hline & $(\mathrm{min})$ & $(\mathrm{mL})$ & $(\mathrm{min})$ & $(\mathrm{mL})$ & $(\mathrm{min})$ & $(\mathrm{mL})$ & $(\mathrm{min})$ & $(\mathrm{mL})$ \\
\hline Pu2 & 95 & 115 & 90 & 65 & NA & NA & 185 & 180 \\
\hline Pu3 & 52 & 105 & 38 & 115 & 44 & 10 & 134 & 230 \\
\hline Pu5 & 79 & 135 & 59 & 80 & NA & NA & 138 & 215 \\
\hline
\end{tabular}

The offgas generation from the dissolution of the Pu metal in Experiments Pu2, Pu3, and Pu5 is plotted in Figure 3-15. The generation rates based on linear regressions were $2 \mathrm{~mL} / \mathrm{min}$ for Experiments Pu3 and Pu5 and $1 \mathrm{~mL} / \mathrm{min}$ for Experiment Pu2. Since the surface area of the Pu metal pieces dissolved in each experiment was approximately the same, the offgas generation rates should be proportional to the metal dissolution rates if the same dissolution mechanisms predominate. The dissolution rates estimated using data from Experiments Pu3 and Pu5 (which differed only in the use of $1 \mathrm{~g} / \mathrm{L} \mathrm{Gd}$ and B, respectively, as the neutron poison) were approximately the same which is consistent with the offgas generation rates. This observation indicates that the presence of $1 \mathrm{~g} / \mathrm{L} \mathrm{Gd}$ or B in the solution had the same general effect on the rate at which the Pu metal dissolved. A similar comparison can be made between Experiments Pu2 and Pu3 which only differed in the use of 0.03 versus $0.05 \mathrm{M} \mathrm{KF}$ and 0.5 versus $1.0 \mathrm{~g} / \mathrm{L} \mathrm{Gd}$, respectively. The offgas generation rate of experiment Pu3 was approximately a factor of 2 higher than the offgas generation rate from experiment Pu2; however, the estimated dissolution rate using data from the flowsheet demonstrations was only about $20 \%$ larger. This difference is likely attributed to different dissolution mechanisms. The concentration of $\mathrm{H}_{2}$ in the offgas was much higher in experiment Pu2 than in experiment Pu3 (see section 3.3.5) which is a clear indication of a difference in the dissolution mechanisms.

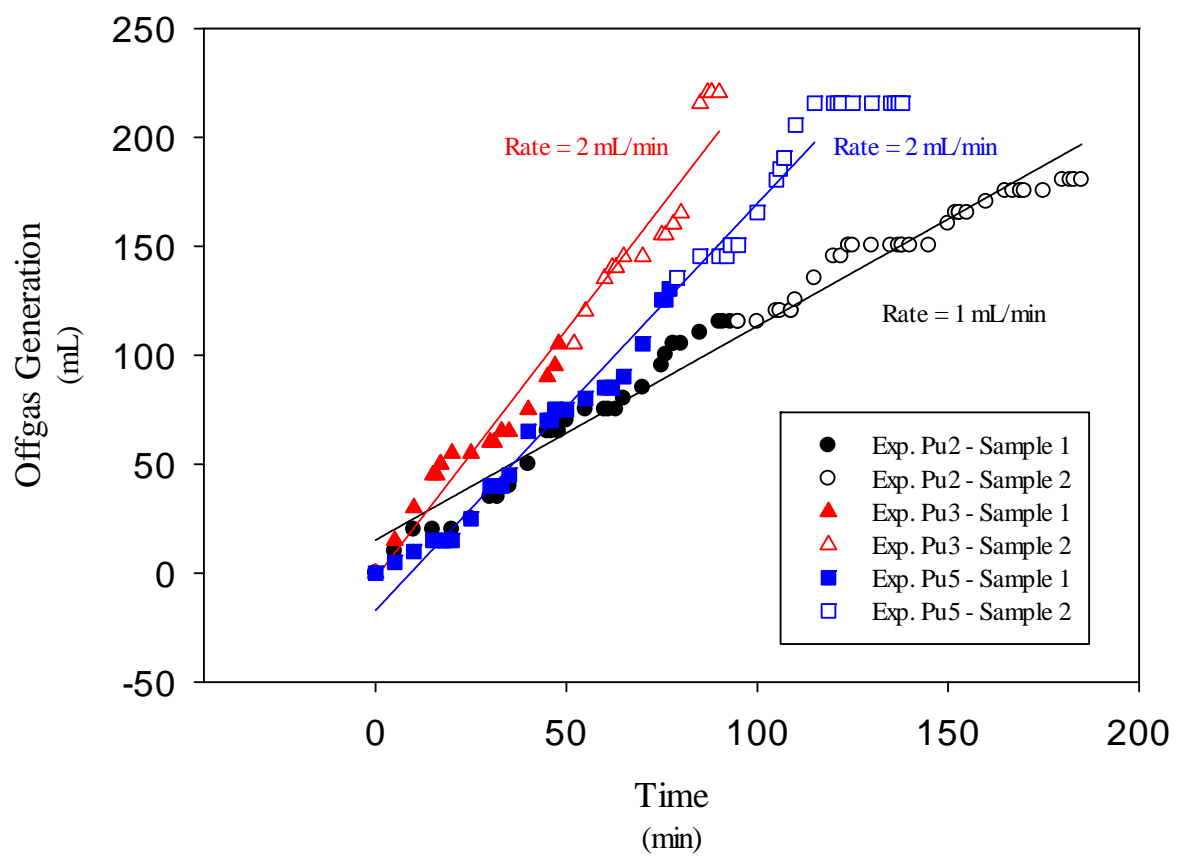

Figure 3-15. Offgas Generation during Pu Metal Dissolution Experiment 
The offgas generation per mole of dissolved Pu was calculated for Experiment Pu3 and Pu5 since the metal completely dissolved during the offgas collection. The values were calculated using the ideal gas law by assuming the pressure of the gas was $1 \mathrm{~atm}$ and the gas was at the temperature of the glovebox. The calculated generation rates are given in Table 3-8.

Table 3-8. Offgas Generation per Mole of Dissolved Pu

\begin{tabular}{||c|c|c|c|c|c|c|c|}
\hline Exp. & $\mathrm{HNO}_{3}$ & $\mathrm{KF}$ & $\mathrm{Gd}$ & $\mathrm{B}$ & $\mathrm{Fe}$ & Glovebox & Offgas \\
\hline & & & & & & Temp. & Gen. \\
\hline & $(\mathrm{M})$ & $(\mathrm{M})$ & $(\mathrm{g} / \mathrm{L})$ & $(\mathrm{g} / \mathrm{L})$ & $(\mathrm{g} / \mathrm{L})$ & $\left({ }^{\circ} \mathrm{C}\right)$ & $(\mathrm{mol}$ offgas/mol Pu$)$ \\
\hline Pu3 & 10 & 0.03 & 0.5 & & 1.9 & 21.0 & 0.6 \\
\hline Pu5 & 10 & 0.05 & & 1.0 & 1.9 & 18.5 & 0.6 \\
\hline \hline
\end{tabular}

The offgas generation in experiments $\mathrm{Pu} 3$ and Pu5 was the same. This observation supports our conclusion that either $1 \mathrm{~g} / \mathrm{L} \mathrm{Gd}$ or B in the dissolving solution had the same general effect on the dissolution rate. Rudisill [1] reported that 0.17 and 0.48 mole offgas/mole Pu were collected during two sample periods when a dissolution was performed using $4 \mathrm{M} \mathrm{HNO}_{3}$ solution containing $0.1 \mathrm{M} \mathrm{KF}$ at $80^{\circ} \mathrm{C}$. The lower offgas generation is likely due to the different dissolution mechanisms which predominate at low (4 M) and high (10 M) $\mathrm{HNO}_{3}$ concentrations. Changes in the dissolution mechanism and the offgas generation rate with changes in acidity have been reported for the dissolution of other metals such as Be, Al, and U.[3, 15-16]

\subsubsection{Offgas Composition}

The composition of the offgas samples collected during Experiments Pu2, Pu3, and Pu5 was analyzed by gas chromatography. The raw data from the gas analyses were adjusted to account for dilution from gas in the dissolution vessel, condenser, Viton ${ }^{\circledR}$ tubing, and sample bulb. The methodology used to calculate the adjusted concentrations is summarized in Appendix C. The measured and adjusted $\mathrm{H}_{2}$ and nitric oxide (NO) concentrations in the offgas samples from the three dissolutions are given in Table 3-9. The one sigma uncertainty in the analyses is $\pm 20 \%$ in the reported values. The one sigma uncertainty in the adjusted concentrations was calculated using propagation of error techniques. The calculations are summarized in Appendix C. The calculations assume the uncertainties in the volume measurements are significantly less than the $\pm 20 \%$ uncertainty in the gas analyses. The relative standard deviation for each adjusted concentration is provided in Table 3-9.

The only other gas detected during the analyses was $\mathrm{N}_{2}$. The presence of $\mathrm{N}_{2}$ is due to purging the air from the dissolving system and the sample bulbs. Nitrogen was not likely generated during the $\mathrm{Pu}$ metal dissolutions. Nitric oxide was produced during the dissolutions. The dissolutions also produced $\mathrm{NO}_{2}$ as a component of the offgas which was identified by the light brown color of the collected gas; however, the gas chromatograph (GC) configuration was not capable of this analysis. The concentrations of the gas species detected by the GC were normalized to $99-100 \%$; therefore, the reported concentrations are biased high by the unquantified amount of $\mathrm{NO}_{2}$ in each sample.

Within the uncertainty of the analysis, the adjusted $\mathrm{H}_{2}$ concentrations measured in the offgas from Experiments Pu3 and Pu5 were approximately the same. Since the dissolution rates estimated from the flowsheet demonstrations and the offgas generation data were nearly the same, the $\mathrm{Pu}$ metal dissolutions likely proceeded by similar mechanisms which resulted in the generation of comparable $\mathrm{H}_{2}$ concentrations in the offgas. However, the adjusted $\mathrm{NO}$ concentrations measured in the offgas from the two experiments were not consistent. Several of the adjusted values in Experiment Pu3 exceeded 100\%. The inconsistency in the data and poor material balance closure 
could be attributed to the uncertainty in the analysis and poor mixing of the gases in the dissolution system. In addition, a portion of the $\mathrm{NO}$ may also have been converted to $\mathrm{NO}_{2}$ by reaction with oxygen due to the leakage of air into the dissolving system. The higher $\mathrm{H}_{2}$ concentrations measured in Experiment Pu2 indicate increased dissolution by a metal/acid reaction rather than nitrate oxidation which results in the production of nitrogen oxides. The higher concentration of $\mathrm{H}_{2}$ in the second sample could be attributed to the reduced activity of the fluoride due to complexation with $\mathrm{Pu}$.

Table 3-9. Composition of Offgas from Pu Metal Dissolutions in $10 \mathrm{M} \mathrm{HNO}_{3}$

\begin{tabular}{|c|c|c|c|c|c|c|c|c|c|}
\hline Exp. & KF & Gd & B & $\mathrm{Fe}$ & Sample & Measured & Adjust. & Measured & Adjust. \\
\hline & & & & & & $\mathrm{H}_{2}{ }^{(1)}$ & $\mathrm{H}_{2}^{(2)}$ & $\mathrm{NO}^{(1)}$ & $\mathrm{NO}^{(2)}$ \\
\hline & (M) & $(g / L)$ & $(\mathrm{g} / \mathrm{L})$ & $(g / L)$ & & (vol \%) & (vol \%) & (vol \%) & (vol \%) \\
\hline \multirow[t]{6}{*}{ Pu2 } & 0.03 & 0.5 & & 1.9 & 1 & 0.60 & $2.2(20)$ & 8.4 & $31(20)$ \\
\hline & & & & & 1 & 0.64 & $2.4(20)$ & 8.9 & $33(20)$ \\
\hline & & & & & ave. & 0.62 & $2.3(20)$ & 8.7 & $32(20)$ \\
\hline & & & & & 2 & 1.9 & $8.5(27)$ & 21 & $86(30)$ \\
\hline & & & & & 2 & 2.0 & $9.1(26)$ & 19 & $75(31)$ \\
\hline & & & & & ave. & 2.0 & 8.8 (27) & 20 & $80(31)$ \\
\hline \multirow[t]{8}{*}{ Pu3 } & 0.05 & 1.0 & & 1.9 & 1 & 0.15 & $0.53(20)$ & 28 & $99(20)$ \\
\hline & & & & & 1 & 0.15 & $0.53(20)$ & 27 & $95(20)$ \\
\hline & & & & & ave. & 0.15 & $0.53(20)$ & 28 & $97(20)$ \\
\hline & & & & & 2 & 0.23 & 0.47 (35) & 61 & $148(28)$ \\
\hline & & & & & 2 & 0.23 & $0.47(35)$ & 58 & $138(29)$ \\
\hline & & & & & ave. & 0.23 & 0.47 (35) & 60 & $143(29)$ \\
\hline & & & & & 3 & $<0.1$ & NA & NA & NA \\
\hline & & & & & 3 & $<0.1$ & NA & NA & NA \\
\hline \multirow[t]{6}{*}{ Pu5 } & 0.05 & & 1.0 & 1.9 & 1 & 0.25 & $0.73(20)$ & 16 & $47(20)$ \\
\hline & & & & & 1 & 0.30 & $0.88(20)$ & 13 & $38(20)$ \\
\hline & & & & & ave. & 0.28 & $0.81(20)$ & 15 & $43(20)$ \\
\hline & & & & & 2 & 0.42 & $1.0(38)$ & 28 & 79 (32) \\
\hline & & & & & 2 & 0.41 & 0.99 (39) & 26 & $71(33)$ \\
\hline & & & & & ave. & 0.42 & $1.0(38)$ & 27 & $75(32)$ \\
\hline
\end{tabular}

(1) $\pm 20 \%$ relative standard deviation

(2) Relative standard deviation shown in parentheses

\subsubsection{H-Canyon Dissolver Purge}

Without controls, the volume of $\mathrm{H}_{2}$ generated during the dissolution of Pu metal in an H-Canyon dissolver must be maintained below $25 \%$ of the lower flammability limit (LFL). When automatic instrumentation with safety interlocks is provided, the combustion concentration is permitted to be maintained at or below $60 \%$ of the LFL.[17] To determine the minimum dissolver purge, the volumetric $\mathrm{H}_{2}$ generation rate was initially calculated from the volume of offgas collected during Experiments Pu2, Pu3, and Pu5, the adjusted $\mathrm{H}_{2}$ concentrations measured in the offgas samples, the masses of Pu metal dissolved, and the dissolution times. The offgas generation rate during $\mathrm{Pu}$ metal dissolution is a function of surface area; however, the mass to surface area ratio of the coupons used in the experiments (i.e., thin sheets) is conservative compared to other geometries such as metal ingots or buttons. The $\mathrm{H}_{2}$ generation rates were scaled to an $\mathrm{H}$-Canyon dissolver based on a charge of $46 \mathrm{~kg}$ of Pu metal. The calculation of the $\mathrm{H}_{2}$ generation rates for the three experiments and the one sigma uncertainties are summarized in Appendix C. The generation rates including uncertainties are shown in Table 3-10. 
SRNL-STI-2012-00043

Revision 0

Table 3-10. $\mathrm{H}_{2}$ Generation Rate from an H-Canyon Dissolver

\begin{tabular}{|c|c|c|c||}
\hline \hline Experiment & $\mathrm{H}_{2}$ & Std. Dev. & Rel. Std. Dev. \\
\hline & Gen. Rate & $\mathrm{H}_{2}$ Gen. Rate & $\mathrm{H}_{2}$ Gen. Rate \\
\hline & $\left(\mathrm{ft}^{3} / \mathrm{min} @\right.$ STP $)$ & $\left(\mathrm{ft}^{3} / \mathrm{min} @\right.$ STP $)$ & $(\%)$ \\
\hline $\mathrm{Pu} 2$ & 0.040 & 0.011 & 28 \\
\hline $\mathrm{Pu} 3$ & 0.0039 & 0.0008 & 21 \\
\hline $\mathrm{Pu} 5$ & 0.0072 & 0.0028 & 39 \\
\hline
\end{tabular}

STP - standard temperature and pressure

To calculate the minimum dissolver purge rate, the LFL for $\mathrm{H}_{2}$ (at $25{ }^{\circ} \mathrm{C}$ and $1 \mathrm{~atm}$ ) in air or oxygen (4 vol \%) was used for illustration.[18] Although the LFL for $\mathrm{H}_{2}$ is a function of the offgas composition and temperature, the value for air was used for simplicity since the calculated $\mathrm{H}_{2}$ generation rates were so small. The minimum purge rates for an $\mathrm{H}$-Canyon dissolver based on the data from Experiments Pu2, Pu3, and Pu5 are given in Table 3-11.

Table 3-11. Minimum Purge Rate for an H-Canyon Dissolver

\begin{tabular}{||c|c|}
\hline Experiment & Purge Rate \\
\hline & $\left(\mathrm{ft}^{3} / \mathrm{min} @\right.$ STP $)$ \\
\hline $\mathrm{Pu} 2$ & 1.7 \\
\hline $\mathrm{Pu} 3$ & 0.2 \\
\hline $\mathrm{Pu} 5$ & 0.3 \\
\hline
\end{tabular}

The minimum air purge rate for either the 6.1D or $6.4 \mathrm{D}$ dissolver is $40 \mathrm{ft}^{3} / \mathrm{min}$ (@ STP); [19] therefore, as long as the dissolvers are purged, the $\mathrm{H}_{2}$ concentration will be diluted well below $60 \%$ of the LFL.

\subsubsection{Pu Oxidation State}

Following the completion of each of the flowsheet demonstration experiments, a small aliquot of the dissolving solution was examined by UV-visible spectroscopy to determine the oxidation state of the Pu. The spectrum for each solution (Figure 3-16) showed that essentially all of the Pu was present as $\mathrm{Pu}(\mathrm{IV})$ based on the absorbance at $831 \mathrm{~nm}$. The concentration of $\mathrm{Pu}(\mathrm{VI})$ in the solutions was estimated to be significantly less than $1 \mathrm{wt} \%$, although the actual detection limit was not established. The UV-visible spectra were recorded within approximately one week of the dissolution experiments. 


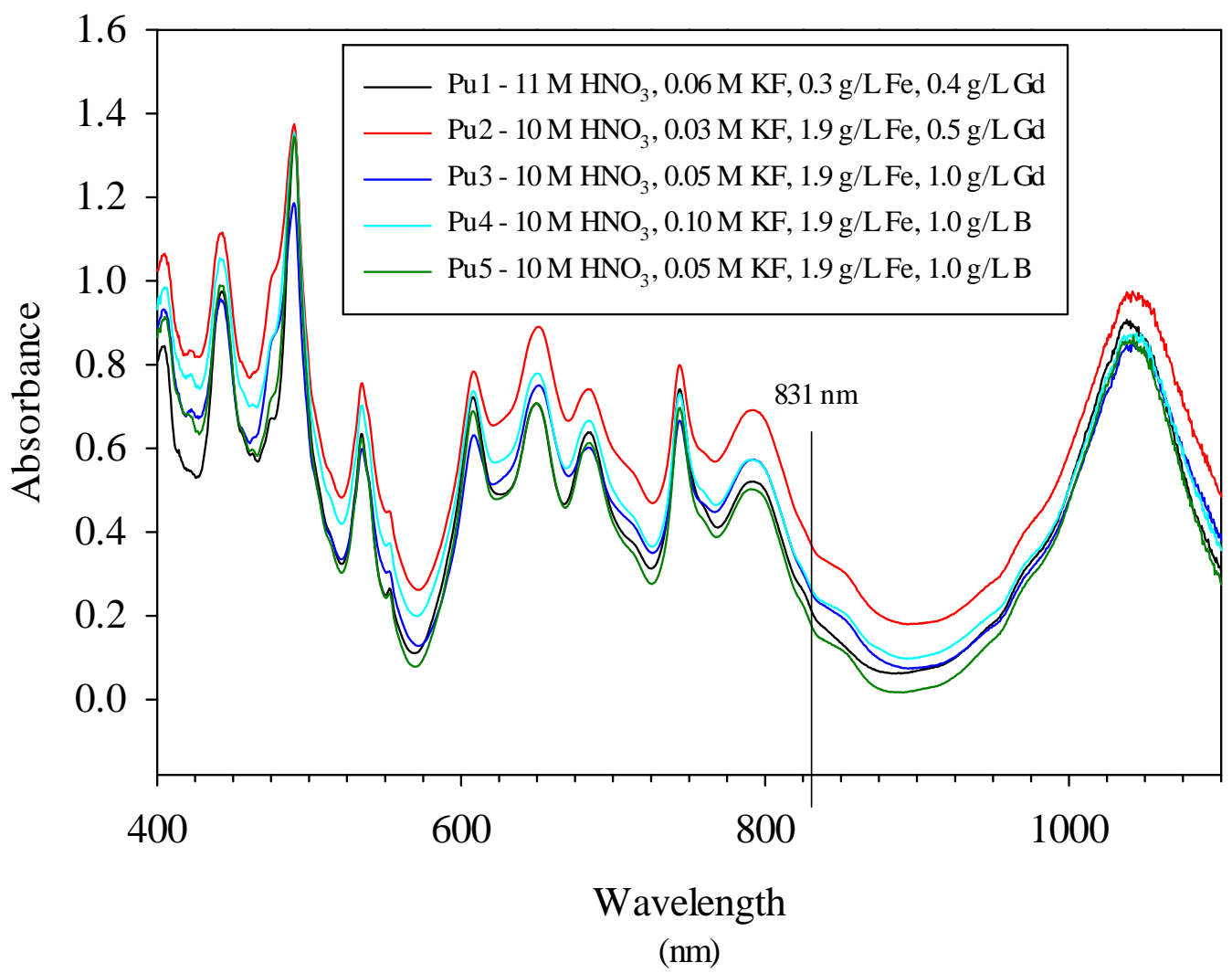

Figure 3-16. UV-visible Spectra of Pu Dissolving Solutions

\subsubsection{Dissolving Solution Analysis}

Samples of the solution following dissolution of the Pu metal coupons were analyzed for metals by ICPES. The analyses for the dissolutions are provided in Appendix D. The metals analysis provides confirmation that the dissolving solutions were at their targeted composition. A comparison of the analyzed compositions and the compositions based on the preparation of each solution is shown in Table 3-12.

Table 3-12. Analysis of Pu Metal Dissolving Solutions

\begin{tabular}{|c|c|c|c|c|c|c|c|c|}
\hline \hline Exp. & ICPES $^{(1)}$ & Prep. & ICPES $^{(1)}$ & Prep. & ICPES $^{(1)}$ & Prep. & ICPES $^{(1)}$ & Prep. \\
\hline & $\mathrm{K}$ & $\mathrm{KF}$ & $\mathrm{Gd}$ & $\mathrm{Gd}$ & $\mathrm{B}$ & $\mathrm{B}$ & $\mathrm{Fe}$ & $\mathrm{Fe}$ \\
\hline & $(\mathrm{M})$ & $(\mathrm{M})$ & $(\mathrm{g} / \mathrm{L})$ & $(\mathrm{g} / \mathrm{L})$ & $(\mathrm{g} / \mathrm{L})$ & $(\mathrm{g} / \mathrm{L})$ & $(\mathrm{g} / \mathrm{L})$ & $(\mathrm{g} / \mathrm{L})$ \\
\hline Pu2 & 0.0294 & 0.03 & 0.501 & 0.50 & & & 2.03 & 1.9 \\
\hline Pu3 & 0.0476 & 0.05 & 1.00 & 1.00 & & & 2.06 & 1.9 \\
\hline Pu4 & 0.0951 & 0.10 & & & 1.00 & 1.0 & 1.97 & 1.9 \\
\hline Pu5 & 0.0496 & 0.05 & & & 1.05 & 1.0 & 2.05 & 1.9 \\
\hline
\end{tabular}

(1) $\pm 10 \%$ relative standard deviation

The free acid concentrations of the Pu metal dissolving solutions were analyzed by titration. The results from the analyses are provided for each experiment in Table 3-13. An adjustment to the $\mathrm{HNO}_{3}$ concentration would not be required for solutions with these acidities prior to purification by anion exchange in HB-Line. 
SRNL-STI-2012-00043

Revision 0

Table 3-13 Free Acid Analysis for Pu Metal Dissolving Solutions

\begin{tabular}{||c|c||}
\hline Experiment & Free Acid \\
\hline & Conc. $^{(1)}$ \\
\hline & (M) \\
\hline $\mathrm{Pu} 2$ & 9.31 \\
\hline $\mathrm{Pu} 3$ & 8.85 \\
\hline $\mathrm{Pu} 4$ & 9.00 \\
\hline $\mathrm{Pu} 5$ & 9.38 \\
\hline
\end{tabular}

(1) $\pm 10 \%$ relative standard deviation

\subsection{Conclusions}

The selection of Pu metal dissolution conditions for H-Canyon can be based on the thickness of materials being dissolved. However, assuming the dissolution of a standard $2250 \mathrm{~g}$ button within a $24 \mathrm{~h}$ period, the required Pu metal dissolution rate is $20 \mathrm{mg} / \mathrm{min}-\mathrm{cm}^{2}$. If $\mathrm{Gd}$ is used as a nuclear poison, the optimum dissolution conditions occur in $10 \mathrm{M} \mathrm{HNO}_{3}, 0.04-0.05 \mathrm{M} \mathrm{KF}$, and 0.5-1.0 g/L Gd at boiling. This will yield a dissolution rate of $\sim 11-15 \mathrm{mg} / \mathrm{min}-\mathrm{cm}^{2}$ and will result in dissolution times of 36-48 $\mathrm{h}$ for standard buttons. The recommended minimum and maximum $\mathrm{KF}$ concentrations are $0.03 \mathrm{M}$ and $0.07 \mathrm{M}$, respectively. The maximum KF concentration is dictated by a potential room-temperature Pu-Gd-F precipitation issue at low Pu concentrations.

The Pu-precipitation issue associated with Gd does not exist if $\mathrm{B}$ is used as the nuclear poison; however, the $\mathrm{B}$ concentration must be maintained below the $\mathrm{H}_{3} \mathrm{BO}_{3}$ solubility limit and the $\mathrm{KF}$ concentration must not exceed the value where $\mathrm{B}$ precipitates as $\mathrm{KBF}_{4}$. Testing at 8-10 $\mathrm{M} \mathrm{HNO}_{3}$, 0.1-0.2 M KF, and 1-2 g/L B indicates that $\sim 20-35 \mathrm{mg} / \mathrm{min}-\mathrm{cm}^{2}$ dissolution rates can be achieved at boiling. The concentration of $\mathrm{B}$ in solution did not appear to have a significant effect on the dissolution rate. The data also indicate that lower KF concentrations would yield dissolution rates for B comparable to those observed with $\mathrm{Gd}$ at the same $\mathrm{HNO}_{3}$ concentration and dissolution temperature.

Small-scale experiments were subsequently used to demonstrate the dissolution of Pu metal up to $6.75 \mathrm{~g} / \mathrm{L}$ in $\mathrm{HNO}_{3}-\mathrm{KF}$ solutions representative of the optimal conditions defined by the dissolution rate measurements. The use of $10 \mathrm{M} \mathrm{HNO}_{3}$ containing 0.03-0.05 M KF, 1.9 g/L Fe, and $0.5-1.0 \mathrm{~g} / \mathrm{L}$ Gd resulted in complete dissolution of the metal in 2.0-3.5 h. When B was used as the neutron poison, $10 \mathrm{M} \mathrm{HNO}_{3}$ solutions containing 0.05-0.1 M KF, $1.9 \mathrm{~g} / \mathrm{L} \mathrm{Fe}$, and $1 \mathrm{~g} / \mathrm{L} \mathrm{B}$ resulted in complete dissolution of the metal in 0.75-2.0 h. No residues were observed following the dissolutions in either the Gd or B systems. Dissolution rates estimated using data from the flowsheet demonstrations agreed reasonably well with the measured rates; although, a discrepancy was observed in the Gd system. The estimated rates for experiments performed using the same KF concentration with $1 \mathrm{~g} / \mathrm{L}$ Gd or B were nominally the same. This observation indicates that the presence of Gd or B in the dissolving solution had about the same effect on the dissolution rate. The predominant $\mathrm{Pu}$ valence in the dissolving solution was $\mathrm{Pu}(\mathrm{IV})$. The concentration of $\mathrm{Pu}(\mathrm{VI})$ was evaluated by UV-visible spectroscopy and was estimated to be significantly less than $1 \mathrm{wt} \%$.

The offgas generation rates and $\mathrm{H}_{2}$ concentrations measured in the offgas from the experiments performed using $10 \mathrm{M} \mathrm{HNO}_{3}$ containing $0.05 \mathrm{M} \mathrm{KF}, 1.9 \mathrm{~g} / \mathrm{L} \mathrm{Fe}$ and either $1 \mathrm{~g} / \mathrm{L} \mathrm{Gd}$ or B were approximately the same. These data support our conclusion that the presence of either $1 \mathrm{~g} / \mathrm{L} \mathrm{Gd}$ or B had the same general effect on the dissolution rate. The offgas generation data also indicate that the dissolutions likely proceeded by the same mechanisms. The calculated offgas generation during the dissolutions was $0.6 \mathrm{~mol}$ offgas $/ \mathrm{mol}$ of $\mathrm{Pu}$. The $\mathrm{H}_{2}$ concentration measured in the 
offgas from the dissolution using Gd as the neutron poison was approximately $0.5 \mathrm{vol} \%$. In the B system, the $\mathrm{H}_{2}$ ranged from nominally 0.8 to 1 vol \% which is approximately the same as measured in the Gd system within the uncertainty of the analysis. The offgas generation rate for the dissolution performed using $10 \mathrm{M} \mathrm{HNO}_{3}$ containing $0.03 \mathrm{M} \mathrm{KF}, 0.5 \mathrm{~g} / \mathrm{L} \mathrm{Gd}$, and $1.9 \mathrm{~g} / \mathrm{L} \mathrm{Fe}$ was approximately a factor of two less than the dissolutions performed using $0.05 \mathrm{M} \mathrm{KF}$ and $1 \mathrm{~g} / \mathrm{L} \mathrm{Gd}$ or B; however, the concentration of $\mathrm{H}_{2}$ measured in the offgas was higher. The adjusted concentration ranged from 2.7 to 8.8 vol \%. Higher concentrations of $\mathrm{H}_{2}$ occur when the dissolution proceeds by a metal/acid reaction rather than nitrate oxidation. In the experiment performed with $0.03 \mathrm{M} \mathrm{KF}$, the higher concentration of $\mathrm{H}_{2}$ (in the second sample) could be attributed to the reduced activity of the fluoride due to complexation with $\mathrm{Pu}$.

Dissolution of Pu metal at $20^{\circ} \mathrm{C}$ and $35^{\circ} \mathrm{C}$ in $10 \mathrm{M} \mathrm{HNO}_{3}$ containing $0.05 \mathrm{M} \mathrm{KF}$ showed that the $\mathrm{Pu}$ metal dissolves slowly without any visible gas generation. At $20^{\circ} \mathrm{C}$, as the $\mathrm{Pu}$ metal dissolves, it forms a more-dense Pu-bearing solution which sinks to the bottom of the dissolution vessel. The dissolved Pu did not form a boundary layer around the sample, but distribution throughout the dissolver solution was limited due to the absence of mixing. At $35{ }^{\circ} \mathrm{C}$, the dissolved $\mathrm{Pu}$ distributed evenly throughout the dissolver solution, probably due to thermal currents caused by maintaining the solution $35{ }^{\circ} \mathrm{C}$. The dispersion of Pu by thermal currents indicates that minimal mixing will be required to disperse dissolved Pu that descends away from the metal surface into the bulk dissolver solution.

\subsection{Flowsheet Recommendations}

The use of a $10 \mathrm{M} \mathrm{HNO}_{3}$ solution containing 0.04-0.05 M KF and 0.5-1.0 g/L Gd at 112 to $116{ }^{\circ} \mathrm{C}$ (boiling) is recommended for the dissolution of Pu metal in H-Canyon up to $6.75 \mathrm{~g} / \mathrm{L}$. The recommended minimum and maximum KF concentrations are $0.03 \mathrm{M}$ and $0.07 \mathrm{M}$, respectively. The maximum KF concentration is dictated by a potential room-temperature Pu-Gd-F precipitation issue at low $\mathrm{Pu}$ concentrations. If $\mathrm{B}$ is used as the neutron poison instead of $\mathrm{Gd}$, we recommend the use of 8-10 $\mathrm{M} \mathrm{HNO}_{3}$ containing 0.1-0.2 M KF and 1-2 g/L B at 112 to $116{ }^{\circ} \mathrm{C}$ (boiling). The maximum KF concentration is $0.22 \mathrm{M}$, although considerations for corrosion control must be taken into account. The low-temperature $\mathrm{Pu}$ precipitation issue associated with the use of Gd does not occur for dissolution with $\mathrm{B}$; however, the $\mathrm{B}$ concentration must be maintained below the $\mathrm{H}_{3} \mathrm{BO}_{3}$ solubility limit and the $\mathrm{KF}$ concentration must not exceed the value where $\mathrm{B}$ precipitates as $\mathrm{KBF}_{4}$.

The dissolution of Pu metal using either the Gd or B system will generate small amounts of $\mathrm{H}_{2}$ which is a flammability concern. Dilution below $60 \%$ of the LFL is required when automatic instrumentation with safety interlocks is provided. To determine the minimum dissolver purge, the volumetric $\mathrm{H}_{2}$ generation rate was initially calculated using the experimental data and a dissolver charge of $46 \mathrm{~kg}$ of Pu metal. The required purge rates for $60 \%$ of the $\mathrm{LFL} \mathrm{of} \mathrm{H}_{2}$ in air ranged from 0.16 to $1.7 \mathrm{ft}^{3} / \mathrm{min}$ (@STP); therefore, the minimum air purge rate of either the 6.1D or $6.4 \mathrm{D}$ dissolver ( $40 \mathrm{ft}^{3} / \mathrm{min} @ \mathrm{STP}$ ) will dilute the $\mathrm{H}_{2}$ concentration well below $60 \%$ of the LFL. 


\subsection{References}

1. T. S. Rudisill and M. L. Crowder, Dissolution of FB-Line Residues Containing Beryllium Metal, WSRC-TR-2005-00042, Rev. 1, Westinghouse Savannah River Company, Aiken, SC (October 2005).

2. T. S. Rudisill, M. L. Crowder, and M. G. Bronikowski, Dissolution of FB-Line Metal Residues Containing Beryllium in H-Canyon, WSRC-TR-2005-00329, Westinghouse Savannah River Company, Aiken, SC (July 2005).

3. T. S. Rudisill, M. L. Crowder, and M. G. Bronikowski, Dissolution of Fissile Materials Containing Vanadium and Tantalum Metals, WSRC-TR-2006-00159, Westinghouse Savannah River Company, Aiken, SC (May 2006).

4. T. S. Rudisill, M. L. Crowder, M.G. Bronikowski, Dissolution of Fissile Materials Containing Tantalum Metals, WSRC-STI-2007-00285, Westinghouse Savannah River Company, Aiken, SC (May 2007).

5. F. J. Miner, J. H. Nairn, and J. W. Berry, Dissolution of Plutonium in Dilute Nitric Acid, I\&EC Product Research and Development, 8, pp. 402-405 (1969).

6. H. P. Holcomb, Dissolving Alpha-phase Plutonium Metal, WSRC-RP-89-00616, Westinghouse Savannah River Company, Aiken, SC (July 1989).

7. H. P. Holcomb, Laboratory-scale Dissolution of Delta-phase Plutonium Metal, WSRC-TR90-0101, Westinghouse Savannah River Company, Aiken, SC (March 1990).

8. W. H. Clifton, Jr., Flowsheet Evaluation for the Dissolving of Plutonium Metal, Technical Task Request No. NMMD-HTS-2011-3173, Savannah River Nuclear Solutions, Aiken, SC (October 3, 2011).

9. R. A. Pierce, Task Technical and Quality Assurance Plan for Dissolution of Plutonium Metal in High Concentrations of Nitric Acid, SRNL-RP-2011-01502, Savannah River National Laboratory, Aiken, SC (October 6, 2011).

10. R. A. Pierce, Dissolution of Plutonium and Uranium Metal Composite Materials, SRNL-STI2010-00638, Rev. 1, Savannah River National Laboratory, Aiken, SC, (February 2011).

11. R. A. Pierce and J. H. Gray, Effect of Plutonium and Aluminum on Gadolinium-Potassium Fluoride Solubility in Nitric Acid, SRNL-STI-2008-00043, Savannah River National Laboratory (October 2008).

12. M. L. Hyder, W. C. Perkins, M. C. Thompson, G. A. Burney, E. R. Russell, H. P. Holcomb, and L. F. Landon, Processing of Irradiated Enriched Uranium Fuels at the Savannah River Plant, DP-1500, E. I. du Pont de Nemours \& Co., Aiken, SC (April 1979).

13. J. H. Gray, Solubility of Boron Compounds in Nitric Acid Solutions, WSRC-TR-98-00426, Westinghouse Savannah River Company, Aiken, SC (November 1998).

14. L. W. Gray, Rapid Dissolution of Plutonium Metal in Sulfamic Acid Followed by Conversion to a Nitric Acid Matrix, DPSPU 78-30-14, E. I. du Pont de Nemours and Company, Aiken, SC (July 1979).

15. J. T. Long, Engineering for Nuclear Fuel Reprocessing, American Nuclear Society, La Grange Park, IL (1978).

16. R. A. Pierce, Uranium Metal Dissolution in the Presence of Fluoride and Boron, WSRC-TR2003-00500, Savannah River Technology Center, Aiken, SC (November 2003).

17. NFPA ${ }^{\circledR}$ 69, Standard on Explosion Prevention Systems, 2008 Edition, NFPA, Quincy, MA.

18. M. G. Zabetakis, Flammability Characteristics of Combustible Gases and Vapors, Bulletin 627, Bureau of Mines, Department of the Interior, Washington, DC (1965).

19. Technical Safety Requirements, Savannah River Site, H-Canyon and Outside Facilities, S-TSR-H-0006, Revision 3, Savannah River Nuclear Solutions, Aiken, SC (July 2011). 
SRNL-STI-2012-00043

Revision 0

Appendix A Dissolution Experiment Pu1 
$\underline{\text { Sample Analysis }}$

The GPHA for the samples generated during Experiment Pu1 are provided in Appendix B. The

${ }^{239} \mathrm{Pu}$ activities were converted to total $\mathrm{Pu}$ values by assuming the metal coupon was weapons grade Pu containing $94 \mathrm{wt} \%{ }^{239} \mathrm{Pu}$. Before the concentrations were correlated with the dissolution time, they were corrected for the small change in volume which occurred due to the removal of samples and evaporation losses. A small correction was also made for the amount of material removed in samples prior to completing the experiment. The procedure used to correct the concentrations, the calculated values, and the uncertainty analysis are provided in Appendix B. The corrected $\mathrm{Pu}$ and Am concentrations as functions of the dissolution time are plotted on Figure A.1.

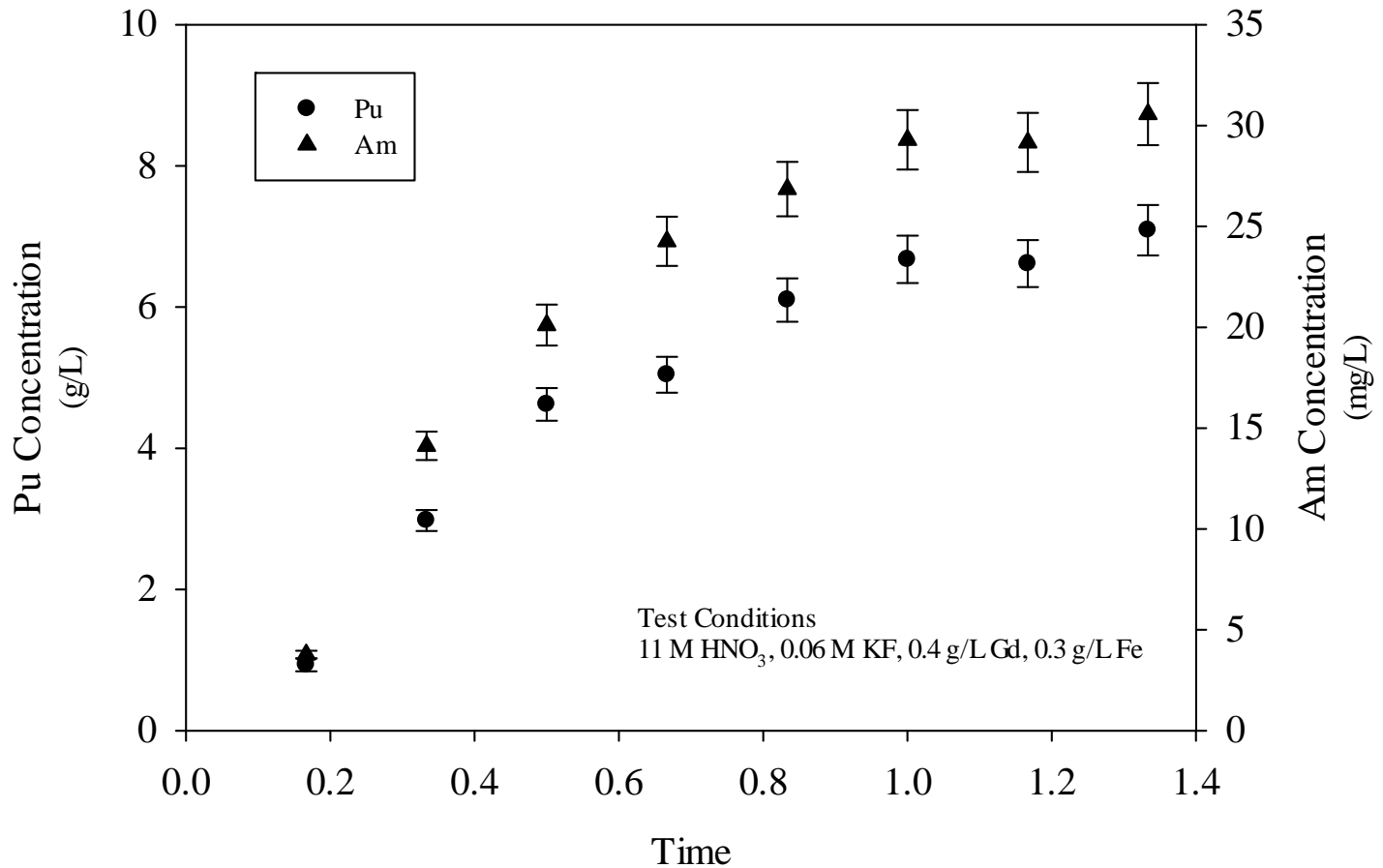

(h)

Figure A.1 Corrected Actinide Concentration in Experiment Pu1

The Pu and Am concentrations show in Figure A.1 are consistent with complete dissolution of the metal coupon. The final concentration $(7.09 \pm 0.35 \mathrm{~g} / \mathrm{L})$ is within about $1 \%$ of the value $(7.16 \pm 0.10 \mathrm{~g} / \mathrm{L})$ predicted by dividing the mass of the coupon by the volume of the dissolving solution. To calculate the amount of $\mathrm{Pu}$ and Am metal dissolved as a function of time, the estimated solution volume and the $\mathrm{Pu}$ and Am concentrations at each sample time were used to calculate the mass of Pu and Am in solution. The calculated mass was expressed as a percentage of the total mass dissolved based on the maximum mass of Pu and Am in solution at the end of the experiment. The calculations including the uncertainty analysis are summarized in Appendix B. The percentage of $\mathrm{Pu}$ and Am dissolved as a function of time is shown in Figure A.2. 


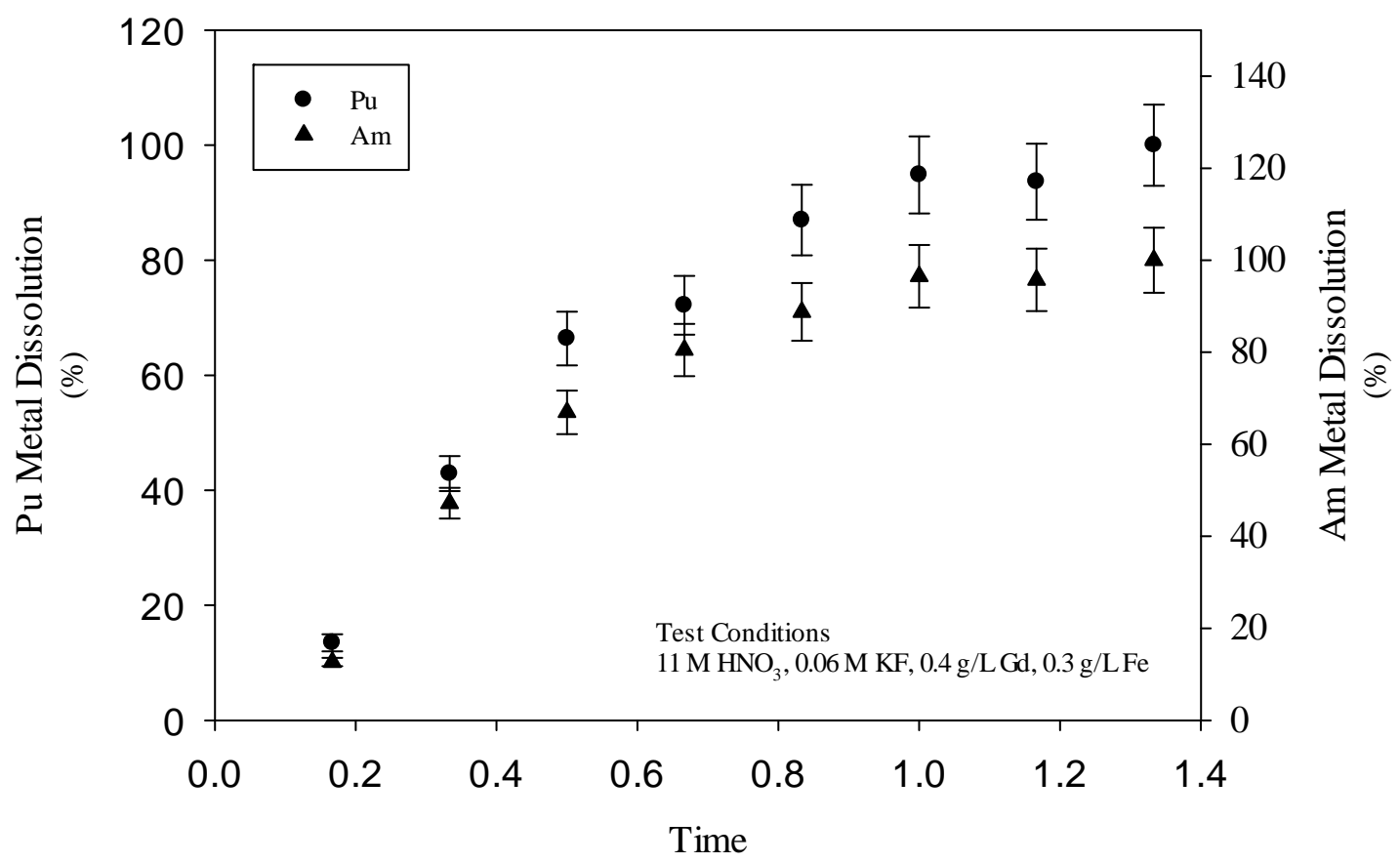

(h)

Figure A.2 Actinide Metal Dissolution in Experiment Pu1

The percentages of Pu and Am dissolved during Experiment Pu1 tracked very closely indicating that the metals dissolved uniformly. The $\mathrm{Pu}$ and Am dissolution curves show that complete dissolution was attained shortly before the experiment was terminated at $1.3 \mathrm{~h}$.

\section{$\underline{\text { Initial Dissolution Rate }}$}

The initial dissolution rate of the Pu metal coupon was estimated using the calculated mass of $\mathrm{Pu}$ dissolved during the early stage of the experiment and the surface area of the metal. Calculation of the rate and the uncertainty analysis are summarized in Appendix B. The calculated value was $13.7 \pm 1.8 \mathrm{mg} / \mathrm{min}-\mathrm{cm}^{2}$.

\section{$\underline{\text { Dissolving Solution Analysis }}$}

Following the dissolution of the Pu metal coupon, a sample of the solution was analyzed for metals by ICPES. The analysis is provided in Appendix D. Table A.1 provides a comparison of the analyzed composition of the dissolving solution and the estimated composition based on the reagent preparation. 
Revision 0

\section{Table A.1. Analysis of Pu Metal Dissolving Solutions}

\begin{tabular}{||c|c|c|}
\hline Component & Analyzed $^{(1)}$ & Estimated \\
\hline & Conc. & Conc. \\
\hline $\mathrm{K}(\mathrm{M})$ & 0.0555 & 0.06 \\
\hline $\mathrm{Gd}(\mathrm{g} / \mathrm{L})$ & 0.398 & 0.4 \\
\hline $\mathrm{Fe}(\mathrm{g} / \mathrm{L})$ & 0.330 & 0.3 \\
\hline
\end{tabular}

(1) $\pm 10 \%$ relative standard deviation

The free acid concentration of the Pu metal dissolving solution was analyzed by titration. The concentration was $10.6 \mathrm{M}$ with a relative standard deviation of $10 \%$. 
SRNL-STI-2012-00043

Revision 0

Appendix B Radiochemical Solution Analysis 


\section{GPHA Data}

The ${ }^{239} \mathrm{Pu}$ and ${ }^{241} \mathrm{Am}$ activities measured by GPHA for the samples of solution from each $\mathrm{Pu}$ dissolution experiment are provided in Tables B.1-B.5.

Table B.1. GPHA for Pu Dissolution Experiment Pu1

\begin{tabular}{||c|c|c|c|c|c||}
\hline Sample ID & Dissolution & ${ }^{239} \mathrm{Pu}$ & 1 sigma & ${ }^{241} \mathrm{Am}$ & 1 sigma \\
\hline & Time & Activity & Uncertainty & Activity & Uncertainty \\
\hline & $(\mathrm{h})$ & $(\mathrm{dpm} / \mathrm{mL})$ & $(\%)$ & $(\mathrm{dpm} / \mathrm{mL})$ & $(\%)$ \\
\hline $\mathrm{Pu} \_10^{(1)}$ & 0.167 & $1.21 \mathrm{E}+08$ & 9.87 & $2.88 \mathrm{E}+07$ & 5.00 \\
\hline $\mathrm{Pu} 2$ & 0.333 & $3.87 \mathrm{E}+08$ & 5.00 & $1.08 \mathrm{E}+08$ & 5.00 \\
\hline $\mathrm{Pu} 33$ & 0.500 & $6.02 \mathrm{E}+08$ & 5.00 & $1.54 \mathrm{E}+08$ & 5.00 \\
\hline $\mathrm{Pu}$ 4 & 0.667 & $6.57 \mathrm{E}+08$ & 5.00 & $1.86 \mathrm{E}+08$ & 5.00 \\
\hline $\mathrm{Pu} 5$ & 0.833 & $7.96 \mathrm{E}+08$ & 5.00 & $2.06 \mathrm{E}+08$ & 5.00 \\
\hline $\mathrm{Pu}$ 6 & 1.000 & $8.72 \mathrm{E}+08$ & 5.00 & $2.25 \mathrm{E}+08$ & 5.00 \\
\hline $\mathrm{Pu}$ 7 & 1.167 & $8.64 \mathrm{E}+08$ & 5.00 & $2.24 \mathrm{E}+08$ & 5.00 \\
\hline $\mathrm{Pu}$ 8 & 1.333 & $9.27 \mathrm{E}+08$ & 5.00 & $2.35 \mathrm{E}+08$ & 5.00 \\
\hline
\end{tabular}

(1) The vial labeled Pu1_10 was inadvertently used instead of the vial labeled Pu_1 at time $0.167 \mathrm{~h}$.

Table B.2. GPHA for Pu Dissolution Experiment Pu2

\begin{tabular}{||c|c|c|c|c|c||}
\hline Sample ID & Dissolution & ${ }^{239} \mathrm{Pu}$ & 1 sigma & ${ }^{241} \mathrm{Am}$ & 1 sigma \\
\hline & Time & Activity & Uncertainty & Activity & Uncertainty \\
\hline & (h) & $(\mathrm{dpm} / \mathrm{mL})$ & $(\%)$ & $(\mathrm{dpm} / \mathrm{mL})$ & $(\%)$ \\
\hline Pu2_1 & 0.25 & $8.40 \mathrm{E}+07$ & 13.9 & $2.61 \mathrm{E}+07$ & 5.00 \\
\hline Pu2_2 & 0.50 & $1.81 \mathrm{E}+08$ & 5.90 & $4.74 \mathrm{E}+07$ & 5.00 \\
\hline Pu2_3 & 0.75 & $2.74 \mathrm{E}+08$ & 5.00 & $6.63 \mathrm{E}+07$ & 5.00 \\
\hline Pu2_4 & 1.00 & $3.26 \mathrm{E}+08$ & 5.00 & $8.51 \mathrm{E}+07$ & 5.00 \\
\hline Pu2_5 & 1.25 & $4.18 \mathrm{E}+08$ & 5.00 & $1.03 \mathrm{E}+08$ & 5.00 \\
\hline Pu2_6 & 1.50 & $4.67 \mathrm{E}+08$ & 5.00 & $1.19 \mathrm{E}+08$ & 5.00 \\
\hline Pu2_7 & 1.75 & $5.05 \mathrm{E}+08$ & 5.00 & $1.35 \mathrm{E}+08$ & 5.00 \\
\hline Pu2_8 & 2.00 & $5.91 \mathrm{E}+08$ & 5.00 & $1.49 \mathrm{E}+08$ & 5.00 \\
\hline Pu2_9 & 2.25 & $6.25 \mathrm{E}+08$ & 5.00 & $1.63 \mathrm{E}+08$ & 5.00 \\
\hline Pu2_10 & 2.50 & $6.83 \mathrm{E}+08$ & 5.00 & $1.76 \mathrm{E}+08$ & 5.00 \\
\hline Pu2_11 & 2.75 & $7.62 \mathrm{E}+08$ & 5.00 & $1.91 \mathrm{E}+08$ & 5.00 \\
\hline Pu2_12 & 3.00 & $7.96 \mathrm{E}+08$ & 5.00 & $1.98 \mathrm{E}+08$ & 5.00 \\
\hline Pu2_13 & 3.25 & $8.02 \mathrm{E}+08$ & 5.00 & $2.07 \mathrm{E}+08$ & 5.00 \\
\hline Pu2_14 & 3.50 & $8.92 \mathrm{E}+08$ & 5.00 & $2.18 \mathrm{E}+08$ & 5.00 \\
\hline Pu2_15 & 3.75 & $8.24 \mathrm{E}+08$ & 5.00 & $2.23 \mathrm{E}+08$ & 5.00 \\
\hline Pu2_16 & 4.00 & $9.06 \mathrm{E}+08$ & 5.00 & $2.36 \mathrm{E}+08$ & 5.00 \\
\hline Pu2_17 & 4.25 & $8.95 \mathrm{E}+08$ & 5.00 & $2.30 \mathrm{E}+08$ & 5.00 \\
\hline
\end{tabular}


Table B.3. GPHA for Pu Dissolution Experiment Pu3

\begin{tabular}{||c|c|c|c|c|c||}
\hline Sample ID & Dissolution & ${ }^{239} \mathrm{Pu}$ & 1 sigma & ${ }^{241} \mathrm{Am}$ & 1 sigma \\
\hline & Time & Activity & Uncertainty & Activity & Uncertainty \\
\hline & (h) & $(\mathrm{dpm} / \mathrm{mL})$ & $(\%)$ & $(\mathrm{dpm} / \mathrm{mL})$ & $(\%)$ \\
\hline Pu3_1 & 0.25 & $2.26 \mathrm{E}+08$ & 7.46 & $6.95 \mathrm{E}+07$ & 5.00 \\
\hline Pu3_2 & 0.50 & NA & NA & NA & NA \\
\hline Pu3_3 & 0.75 & $4.66 \mathrm{E}+08$ & 5.00 & $1.34 \mathrm{E}+08$ & 5.00 \\
\hline Pu3_4 & 1.00 & $5.12 \mathrm{E}+08$ & 5.00 & $1.64 \mathrm{E}+08$ & 5.00 \\
\hline Pu3_5 & 1.25 & $7.00 \mathrm{E}+08$ & 5.00 & $1.98 \mathrm{E}+08$ & 5.00 \\
\hline Pu3_6 & 1.50 & $8.41 \mathrm{E}+08$ & 5.00 & $2.24 \mathrm{E}+08$ & 5.00 \\
\hline Pu3_7 & 1.75 & $7.23 \mathrm{E}+08$ & 5.00 & $2.26 \mathrm{E}+08$ & 5.00 \\
\hline Pu3_8 & 2.00 & $8.96 \mathrm{E}+08$ & 5.00 & $2.19 \mathrm{E}+08$ & 5.00 \\
\hline Pu3_9 & 2.25 & $7.79 \mathrm{E}+08$ & 5.00 & $2.23 \mathrm{E}+08$ & 5.00 \\
\hline
\end{tabular}

(1) Sample vial Pu3_2 was empty. No solution was transferred into the syringe.

Table B.4. GPHA for Pu Dissolution Experiment Pu4

\begin{tabular}{||c|c|c|c|c|c||}
\hline Sample ID & Dissolution & ${ }^{239} \mathrm{Pu}$ & 1 sigma & ${ }^{241}$ Am & 1 sigma \\
\hline & Time & Activity & Uncertainty & Activity & Uncertainty \\
\hline & (h) & $(\mathrm{dpm} / \mathrm{mL})$ & $(\%)$ & $(\mathrm{dpm} / \mathrm{mL})$ & $(\%)$ \\
\hline Pu4_1 & 0.25 & $3.85 \mathrm{E}+08$ & 5.00 & $1.00 \mathrm{E}+08$ & 5.00 \\
\hline Pu4_2 & 0.50 & $6.86 \mathrm{E}+08$ & 5.00 & $1.78 \mathrm{E}+08$ & 5.00 \\
\hline Pu4_3 & 0.75 & $8.77 \mathrm{E}+08$ & 5.00 & $2.24 \mathrm{E}+08$ & 5.00 \\
\hline Pu4_4 & 1.00 & $8.77 \mathrm{E}+08$ & 5.00 & $2.29 \mathrm{E}+08$ & 5.00 \\
\hline Pu4_5 & 1.25 & $8.98 \mathrm{E}+08$ & 5.00 & $2.28 \mathrm{E}+08$ & 5.00 \\
\hline Pu4_6 & 1.50 & $8.87 \mathrm{E}+08$ & 5.00 & $2.26 \mathrm{E}+08$ & 5.00 \\
\hline Pu4_7 & 1.75 & $8.52 \mathrm{E}+08$ & 5.00 & $2.25 \mathrm{E}+08$ & 5.00 \\
\hline Pu4_8 & 2.00 & $8.52 \mathrm{E}+08$ & 5.00 & $2.31 \mathrm{E}+08$ & 5.00 \\
\hline \hline
\end{tabular}

Table B.5. GPHA for Pu Dissolution Experiment Pu5

\begin{tabular}{||c|c|c|c|c|c||}
\hline \hline Sample ID & Dissolution & ${ }^{239} \mathrm{Pu}$ & 1 sigma & ${ }^{241}$ Am & 1 sigma \\
\hline & Time & Activity & Uncertainty & Activity & Uncertainty \\
\hline & $(\mathrm{h})$ & $(\mathrm{dpm} / \mathrm{mL})$ & $(\%)$ & $(\mathrm{dpm} / \mathrm{mL})$ & $(\%)$ \\
\hline Pu5_1 & 0.25 & $2.00 \mathrm{E}+08$ & 5.05 & $4.58 \mathrm{E}+07$ & 5.00 \\
\hline Pu5_2 & 0.50 & $2.55 \mathrm{E}+08$ & 5.00 & $6.15 \mathrm{E}+07$ & 5.00 \\
\hline Pu5_3 & 0.75 & $3.70 \mathrm{E}+08$ & 5.00 & $9.23 \mathrm{E}+07$ & 5.00 \\
\hline Pu5_4 & 1.00 & $4.72 \mathrm{E}+08$ & 5.00 & $1.23 \mathrm{E}+08$ & 5.00 \\
\hline Pu5_5 & 1.25 & $5.96 \mathrm{E}+08$ & 5.00 & $1.50 \mathrm{E}+08$ & 5.00 \\
\hline Pu5_6 & 1.50 & $5.29 \mathrm{E}+08$ & 5.00 & $1.77 \mathrm{E}+08$ & 5.00 \\
\hline Pu5_7 & 1.75 & $8.49 \mathrm{E}+08$ & 5.00 & $2.15 \mathrm{E}+08$ & 5.00 \\
\hline Pu5_8 & 2.00 & $9.11 \mathrm{E}+08$ & 5.00 & $2.34 \mathrm{E}+08$ & 5.00 \\
\hline Pu5_9 & 2.25 & $9.10 \mathrm{E}+08$ & 5.00 & $2.24 \mathrm{E}+08$ & 5.00 \\
\hline
\end{tabular}


The $\mathrm{Pu}$ and Am activities given in Tables B.1-B.5 were converted to a mass basis using the specific activities of ${ }^{239} \mathrm{Pu}$ and ${ }^{241} \mathrm{Am}(1.38 \mathrm{E}+11$ and $7.63 \mathrm{E}+12 \mathrm{dpm} / \mathrm{g}$, respectively). The total $\mathrm{Pu}$ concentrations were subsequently calculated by assuming the ${ }^{239} \mathrm{Pu}$ content of weapons grade $\mathrm{Pu}$ is $94 \mathrm{wt} \%$. The $\mathrm{Pu}$ and Am concentrations for the samples from each dissolution experiment are provided in Tables B.6-B.10.

Table B.6. Actinide Concentrations in Samples from Pu Dissolution Experiment Pu1

\begin{tabular}{||c|c|c|c|c|c||}
\hline \hline Sample ID & Dissolution & Pu & 1 sigma & Am & 1 sigma \\
\hline & Time & Concentration & Uncertainty & Concentration & Uncertainty \\
\hline & $(\mathrm{h})$ & $(\mathrm{g} / \mathrm{L})$ & $(\%)$ & $(\mathrm{mg} / \mathrm{L})$ & $(\%)$ \\
\hline $\mathrm{Pu} \_10$ & 0.17 & 0.933 & 9.87 & 3.77 & 5.00 \\
\hline $\mathrm{Pu} 2$ & 0.33 & 2.98 & 5.00 & 14.2 & 5.00 \\
\hline $\mathrm{Pu} 3$ & 0.50 & 4.64 & 5.00 & 20.2 & 5.00 \\
\hline $\mathrm{Pu}$ 44 & 0.67 & 5.06 & 5.00 & 24.4 & 5.00 \\
\hline $\mathrm{Pu} 55$ & 0.83 & 6.14 & 5.00 & 27.0 & 5.00 \\
\hline $\mathrm{Pu}$ 66 & 1.00 & 6.72 & 5.00 & 29.5 & 5.00 \\
\hline $\mathrm{Pu} 7$ & 1.17 & 6.66 & 5.00 & 29.4 & 5.00 \\
\hline $\mathrm{Pu} 88$ & 1.33 & 7.15 & 5.00 & 30.8 & 5.00 \\
\hline
\end{tabular}

Table B.7. Actinide Concentrations in Samples from Pu Dissolution Experiment Pu2

\begin{tabular}{||c|c|c|c|c|c||}
\hline \hline Sample ID & Dissolution & Pu & 1 sigma & Am & 1 sigma \\
\hline & Time & Concentration & Uncertainty & Concentration & Uncertainty \\
\hline & (h) & $(\mathrm{g} / \mathrm{L})$ & $(\%)$ & $(\mathrm{mg} / \mathrm{L})$ & $(\%)$ \\
\hline Pu2_1 & 0.25 & 0.648 & 13.9 & 3.42 & 5.00 \\
\hline Pu2_2 & 0.50 & 1.40 & 5.90 & 6.21 & 5.00 \\
\hline Pu2_3 & 0.75 & 2.11 & 5.00 & 8.69 & 5.00 \\
\hline Pu2_4 & 1.00 & 2.51 & 5.00 & 11.2 & 5.00 \\
\hline Pu2_5 & 1.25 & 3.22 & 5.00 & 13.5 & 5.00 \\
\hline Pu2_6 & 1.50 & 3.60 & 5.00 & 15.6 & 5.00 \\
\hline Pu2_7 & 1.75 & 3.89 & 5.00 & 17.7 & 5.00 \\
\hline Pu2_8 & 2.00 & 4.56 & 5.00 & 19.5 & 5.00 \\
\hline Pu2_9 & 2.25 & 4.82 & 5.00 & 21.4 & 5.00 \\
\hline Pu2_10 & 2.50 & 5.27 & 5.00 & 23.1 & 5.00 \\
\hline Pu2_11 & 2.75 & 5.87 & 5.00 & 25.0 & 5.00 \\
\hline Pu2_12 & 3.00 & 6.14 & 5.00 & 26.0 & 5.00 \\
\hline Pu2_13 & 3.25 & 6.18 & 5.00 & 27.1 & 5.00 \\
\hline Pu2_14 & 3.50 & 6.88 & 5.00 & 28.6 & 5.00 \\
\hline Pu2_15 & 3.75 & 6.35 & 5.00 & 29.2 & 5.00 \\
\hline Pu2_16 & 4.00 & 6.98 & 5.00 & 30.9 & 5.00 \\
\hline Pu2_17 & 4.25 & 6.90 & 5.00 & 30.1 & 5.00 \\
\hline
\end{tabular}


Table B.8. Actinide Concentrations in Samples from Pu Dissolution Experiment Pu3

\begin{tabular}{||c|c|c|c|c|c||}
\hline Sample ID & Dissolution & Pu & 1 sigma & Am & 1 sigma \\
\hline & Time & Concentration & Uncertainty & Concentration & Uncertainty \\
\hline & $(\mathrm{h})$ & $(\mathrm{g} / \mathrm{L})$ & $(\%)$ & $(\mathrm{mg} / \mathrm{L})$ & $(\%)$ \\
\hline Pu3_1 & 0.25 & 1.74 & 7.46 & 9.11 & 5.00 \\
\hline Pu3_2 & 0.50 & NA & NA & NA & NA \\
\hline Pu3_3 & 0.75 & 3.59 & 5.00 & 17.6 & 5.00 \\
\hline Pu3_4 & 1.00 & 3.95 & 5.00 & 21.5 & 5.00 \\
\hline Pu3_5 & 1.25 & 5.40 & 5.00 & 26.0 & 5.00 \\
\hline Pu3_6 & 1.50 & 6.48 & 5.00 & 29.4 & 5.00 \\
\hline Pu3_7 & 1.75 & 5.57 & 5.00 & 29.6 & 5.00 \\
\hline Pu3_8 & 2.00 & 6.91 & 5.00 & 28.7 & 5.00 \\
\hline Pu3_9 & 2.25 & 6.01 & 5.00 & 29.2 & 5.00 \\
\hline
\end{tabular}

Table B.9. Actinide Concentrations in Samples from Pu Dissolution Experiment Pu4

\begin{tabular}{||c|c|c|c|c|c||}
\hline Sample ID & Dissolution & Pu & 1 sigma & Am & 1 sigma \\
\hline & Time & Concentration & Uncertainty & Concentration & Uncertainty \\
\hline & $(\mathrm{h})$ & $(\mathrm{g} / \mathrm{L})$ & $(\%)$ & $(\mathrm{mg} / \mathrm{L})$ & $(\%)$ \\
\hline Pu4_1 & 0.25 & 2.97 & 5.00 & 13.1 & 5.00 \\
\hline Pu4_2 & 0.50 & 5.29 & 5.00 & 23.3 & 5.00 \\
\hline Pu4_3 & 0.75 & 6.76 & 5.00 & 29.4 & 5.00 \\
\hline Pu4_4 & 1.00 & 6.76 & 5.00 & 30.0 & 5.00 \\
\hline Pu4_5 & 1.25 & 6.92 & 5.00 & 29.9 & 5.00 \\
\hline Pu4_6 & 1.50 & 6.84 & 5.00 & 29.6 & 5.00 \\
\hline Pu4_7 & 1.75 & 6.57 & 5.00 & 29.5 & 5.00 \\
\hline Pu4_8 & 2.00 & 6.57 & 5.00 & 30.3 & 5.00 \\
\hline
\end{tabular}

Table B.10. Actinide Concentrations in Samples from Pu Dissolution Experiment Pu5

\begin{tabular}{||c|c|c|c|c|c||}
\hline \hline Sample ID & Dissolution & Pu & 1 sigma & Am & 1 sigma \\
\hline & Time & Concentration & Uncertainty & Concentration & Uncertainty \\
\hline & $(\mathrm{h})$ & $(\mathrm{g} / \mathrm{L})$ & $(\%)$ & $(\mathrm{mg} / \mathrm{L})$ & $(\%)$ \\
\hline Pu5_1 & 0.25 & 1.54 & 5.05 & 6.00 & 5.00 \\
\hline Pu5_2 & 0.50 & 1.97 & 5.00 & 8.06 & 5.00 \\
\hline Pu5_3 & 0.75 & 2.85 & 5.00 & 12.1 & 5.00 \\
\hline Pu5_4 & 1.00 & 3.64 & 5.00 & 16.1 & 5.00 \\
\hline Pu5_5 & 1.25 & 4.59 & 5.00 & 19.7 & 5.00 \\
\hline Pu5_6 & 1.50 & 4.08 & 5.00 & 23.2 & 5.00 \\
\hline Pu5_7 & 1.75 & 6.54 & 5.00 & 28.2 & 5.00 \\
\hline Pu5_8 & 2.00 & 7.02 & 5.00 & 30.7 & 5.00 \\
\hline Pu5_9 & 2.25 & 7.02 & 5.00 & 29.4 & 5.00 \\
\hline
\end{tabular}

Evaporation Rate

The Pu and Am concentrations in each sample were corrected for small changes in volume which occurred due to sample removal and evaporation losses from the dissolver. A small correction was also made for the Pu and Am removed in samples prior to completing the experiment. The 
volume of the samples removed from the dissolver was nominally $2 \mathrm{~mL}$. The evaporation rate was estimated from the initial and final dissolving solution volumes and the number of samples removed. The calculations are summarized in Table B.11.

Table B.11. Evaporation Rate during Pu Dissolution Experiments

\begin{tabular}{||c|c|c|c|c|c|c|}
\hline Experiment & Initial & Final & Number of & Evaporated & Dissolution & Evaporation \\
\hline No. & Volume & Volume & Samples & Volume & Time & Rate \\
\hline & $(\mathrm{mL})$ & $(\mathrm{mL})$ & & $(\mathrm{mL})$ & $(\mathrm{h})$ & $(\mathrm{mL} / \mathrm{h})$ \\
\hline Pu1 ${ }^{(1)}$ & 575 & 562 & 8 & -3 & 1.33 & 0 \\
\hline Pu2 & 500 & 444 & 17 & 22 & 4.25 & 5.18 \\
\hline Pu3 & 546 & 512 & 9 & 16 & 2.25 & 7.11 \\
\hline Pu4 & 550 & 524 & 8 & 10 & 2.00 & 5.00 \\
\hline Pu5 & 550 & 510 & 9 & 22 & 2.25 & 9.78 \\
\hline
\end{tabular}

(1) With no evaporation, the final volume should be $569 \mathrm{~mL}$. The discrepancy is likely due to the (poor) accuracy of the $2 \mathrm{~L}$ graduated cylinder used to measure the initial volume.

The calculations in Table B.11 assume the evaporation rate was constant during the dissolving experiment; however, the evaporation of solution during the $\mathrm{N}_{2}$ purge (in Experiments $\mathrm{Pu} 2 \mathrm{Pu}$, and Pu5) and the removal of sample volumes greater than $2 \mathrm{~mL}$ may have contributed to the missing volume. The estimated volumes of solution in the dissolver for each dissolution experiment prior to the removal of the sample are given in Tables B.12-B.16.

Table B.12. Estimated Dissolver Volumes for Pu Dissolution Experiment Pu1

\begin{tabular}{||c|c|c|}
\hline Sample ID & Dissolution & Dissolver \\
\hline & Time & Volume \\
\hline & $(\mathrm{h})$ & $(\mathrm{mL})$ \\
\hline $\mathrm{Pu} \_10$ & 0.17 & 575 \\
\hline $\mathrm{Pu} 2$ & 0.33 & 573 \\
\hline $\mathrm{Pu} \_3$ & 0.50 & 571 \\
\hline $\mathrm{Pu}$ 4 & 0.67 & 569 \\
\hline $\mathrm{Pu} 5$ & 0.83 & 567 \\
\hline $\mathrm{Pu}$ 6 & 1.00 & 565 \\
\hline $\mathrm{Pu}$ 7 & 1.17 & 563 \\
\hline $\mathrm{Pu}$ 8 & 1.33 & 561 \\
\hline
\end{tabular}


Table B.13. Estimated Dissolver Volumes for Pu Dissolution Experiment Pu2

\begin{tabular}{||c|c|c|}
\hline Sample ID & Dissolution & Dissolver \\
\hline & Time & Volume \\
\hline & (h) & (mL) \\
\hline Pu2_1 & 0.25 & 499 \\
\hline Pu2_2 & 0.50 & 495 \\
\hline Pu2_3 & 0.75 & 492 \\
\hline Pu2_4 & 1.00 & 489 \\
\hline Pu2_5 & 1.25 & 486 \\
\hline Pu2_6 & 1.50 & 482 \\
\hline Pu2_7 & 1.75 & 479 \\
\hline Pu2_8 & 2.00 & 476 \\
\hline Pu2_9 & 2.25 & 472 \\
\hline Pu2_10 & 2.50 & 469 \\
\hline Pu2_11 & 2.75 & 466 \\
\hline Pu2_12 & 3.00 & 462 \\
\hline Pu2_13 & 3.25 & 459 \\
\hline Pu2_14 & 3.50 & 456 \\
\hline Pu2_15 & 3.75 & 453 \\
\hline Pu2_16 & 4.00 & 449 \\
\hline Pu2_17 & 4.25 & 446 \\
\hline
\end{tabular}

Table B.14. Estimated Dissolver Volumes for Pu Dissolution Experiment Pu3

\begin{tabular}{||c|c|c||}
\hline \hline Sample ID & Dissolution & Dissolver \\
\hline & Time & Volume \\
\hline & (h) & (mL) \\
\hline Pu3_1 & 0.25 & 544 \\
\hline Pu3_2 & 0.50 & 540 \\
\hline Pu3_3 & 0.75 & 538 \\
\hline Pu3_4 & 1.00 & 534 \\
\hline Pu3_5 & 1.25 & 530 \\
\hline Pu3_6 & 1.50 & 526 \\
\hline Pu3_7 & 1.75 & 522 \\
\hline Pu3_8 & 2.00 & 518 \\
\hline Pu3_9 & 2.25 & 514 \\
\hline
\end{tabular}


SRNL-STI-2012-00043

Revision 0

Table B.15. Estimated Dissolver Volumes for Pu Dissolution Experiment Pu4

\begin{tabular}{||c|c|c|}
\hline Sample ID & Dissolution & Dissolver \\
\hline & Time & Volume \\
\hline & (h) & (mL) \\
\hline Pu4_1 & 0.25 & 549 \\
\hline Pu4_2 & 0.50 & 546 \\
\hline Pu4_3 & 0.75 & 542 \\
\hline Pu4_4 & 1.00 & 539 \\
\hline Pu4_5 & 1.25 & 536 \\
\hline Pu4_6 & 1.50 & 533 \\
\hline Pu4_7 & 1.75 & 529 \\
\hline Pu4_8 & 2.00 & 526 \\
\hline
\end{tabular}

Table B.16. Estimated Dissolver Volumes for Pu Dissolution Experiment Pu5

\begin{tabular}{||c|c|c||}
\hline Sample ID & Dissolution & Dissolver \\
\hline & Time & Volume \\
\hline & (h) & (mL) \\
\hline Pu5_1 & 0.25 & 548 \\
\hline Pu5_2 & 0.50 & 543 \\
\hline Pu5_3 & 0.75 & 539 \\
\hline Pu5_4 & 1.00 & 534 \\
\hline Pu5_5 & 1.25 & 530 \\
\hline Pu5_6 & 1.50 & 525 \\
\hline Pu5_7 & 1.75 & 521 \\
\hline Pu5_8 & 2.00 & 516 \\
\hline Pu5_9 & 2.25 & 512 \\
\hline
\end{tabular}

\section{$\underline{\text { Corrected Actinide Concentrations }}$}

The corrected $\mathrm{Pu}$ and Am concentrations were calculated by adjusting for the change in volume and accounting for the small amount of material removed from the dissolving solution in each sample. The generalized expression used to calculate the corrected concentrations $\left(\mathrm{C}_{t_{\text {corrected }}}\right)$ at sample time $t$ is given as equation B.1,

$$
\mathrm{C}_{\mathrm{t}_{\text {corrected }}}=\frac{\mathrm{C}_{\mathrm{t}} \mathrm{V}_{\mathrm{t}}+\sum_{\mathrm{i}=1}^{\mathrm{t}-1} \mathrm{C}_{\mathrm{i}} \mathrm{V}_{\mathrm{s}_{\mathrm{i}}}}{\mathrm{V}_{0}}
$$

where $C_{t}$ and $C_{i}$ are measured concentrations (Tables B.6-B.10), $V_{t}$ is the estimated volume (Tables B.12-B.16), $\mathrm{Vs}_{\mathrm{i}}$ is the sample volume $(2 \mathrm{~mL})$, and $\mathrm{V}_{0}$ is the initial volume (Table B.11). The corrected concentrations for the actinides are given in Table B.17-B.21. 
Table B.17. Corrected Actinide Concentrations for Pu Dissolution Experiment Pu1

\begin{tabular}{|c|c|c|c|}
\hline Sample ID & Dissolution & $\mathrm{Pu}_{\text {corrected }}$ & $\mathrm{Am}_{\text {corrected }}$ \\
\hline & Time & Concentration & Concentration \\
\hline & (h) & $(\mathrm{g} / \mathrm{L})$ & $(\mathrm{mg} / \mathrm{L})$ \\
\hline $\mathrm{Pu} \_10$ & 0.17 & 0.933 & 3.77 \\
\hline $\mathrm{Pu} \_2$ & 0.33 & 2.98 & 14.1 \\
\hline $\mathrm{Pu} \_3$ & 0.50 & 4.62 & 20.1 \\
\hline Pu_4 & 0.67 & 5.04 & 24.3 \\
\hline $\mathrm{Pu} \_5$ & 0.83 & 6.10 & 26.8 \\
\hline $\mathrm{Pu} \_6$ & 1.00 & 6.67 & 29.3 \\
\hline $\mathrm{Pu} \_7$ & 1.17 & 6.61 & 29.2 \\
\hline $\mathrm{Pu} \_8$ & 1.33 & 7.09 & 30.6 \\
\hline
\end{tabular}

Table B.18. Corrected Actinide Concentrations for Pu Dissolution Experiment Pu2

\begin{tabular}{||c|c|c|c||}
\hline Sample ID & Dissolution & $\mathrm{Pu}_{\text {corrected }}$ & $\mathrm{Am}_{\text {corrected }}$ \\
\hline & Time & Concentration & Concentration \\
\hline & $(\mathrm{h})$ & $(\mathrm{g} / \mathrm{L})$ & $(\mathrm{mg} / \mathrm{L})$ \\
\hline Pu2_1 & 0.25 & 0.646 & 3.41 \\
\hline Pu2_2 & 0.50 & 1.39 & 6.17 \\
\hline Pu2_3 & 0.75 & 2.09 & 8.59 \\
\hline Pu2_4 & 1.00 & 2.47 & 11.0 \\
\hline Pu2_5 & 1.25 & 3.16 & 13.2 \\
\hline Pu2_6 & 1.50 & 3.51 & 15.2 \\
\hline Pu2_7 & 1.75 & 3.78 & 17.2 \\
\hline Pu2_8 & 2.00 & 4.40 & 18.9 \\
\hline Pu2_9 & 2.25 & 4.64 & 20.6 \\
\hline Pu2_10 & 2.50 & 5.41 & 22.1 \\
\hline Pu2_11 & 2.75 & 5.60 & 23.9 \\
\hline Pu2_12 & 3.00 & 5.83 & 24.7 \\
\hline Pu2_13 & 3.25 & 5.85 & 25.7 \\
\hline Pu2_14 & 3.50 & 6.47 & 26.9 \\
\hline Pu2_15 & 3.75 & 5.98 & 27.4 \\
\hline Pu2_16 & 4.00 & 6.53 & 28.9 \\
\hline Pu2_17 & 4.25 & 6.44 & 28.1 \\
\hline \hline
\end{tabular}


Table B.19. Corrected Actinide Concentrations for Pu Dissolution Experiment Pu3

\begin{tabular}{||c|c|c|c||}
\hline Sample ID & Dissolution & $\mathrm{Pu}_{\text {corrected }}$ & Am $_{\text {corrected }}$ \\
\hline & Time & Concentration & Concentration \\
\hline & $(\mathrm{h})$ & $(\mathrm{g} / \mathrm{L})$ & $(\mathrm{mg} / \mathrm{L})$ \\
\hline Pu3_1 & 0.25 & 1.74 & 9.08 \\
\hline Pu3_2 & 0.50 & NA & NA \\
\hline Pu3_3 & 0.75 & 3.55 & 17.3 \\
\hline Pu3_4 & 1.00 & 3.88 & 21.1 \\
\hline Pu3_5 & 1.25 & 5.27 & 25.4 \\
\hline Pu3_6 & 1.50 & 6.30 & 28.6 \\
\hline Pu3_7 & 1.75 & 5.41 & 28.7 \\
\hline Pu3_8 & 2.00 & 6.65 & 27.7 \\
\hline Pu3_9 & 2.25 & 5.78 & 28.1 \\
\hline
\end{tabular}

Table B.20. Corrected Actinide Concentrations for Pu Dissolution Experiment Pu4

\begin{tabular}{||c|c|c|c||}
\hline Sample ID & Dissolution & Pu $_{\text {corrected }}$ & Am $_{\text {corrected }}$ \\
\hline & Time & Concentration & Concentration \\
\hline & $(\mathrm{h})$ & $(\mathrm{g} / \mathrm{L})$ & $(\mathrm{mg} / \mathrm{L})$ \\
\hline $\mathrm{Pu} 4 \_1$ & 0.25 & 2.96 & 13.1 \\
\hline $\mathrm{Pu} 4 \_2$ & 0.50 & 5.26 & 23.2 \\
\hline $\mathrm{Pu} 4$ 3 & 0.75 & 6.70 & 29.1 \\
\hline $\mathrm{Pu} 4$ 4 & 1.00 & 6.68 & 29.7 \\
\hline $\mathrm{Pu} 4$ 5 & 1.25 & 6.82 & 29.5 \\
\hline $\mathrm{Pu} 4$ 6 & 1.50 & 6.72 & 29.1 \\
\hline Pu4_7 & 1.75 & 6.45 & 28.9 \\
\hline Pu4_8 & 2.00 & 6.43 & 29.6 \\
\hline
\end{tabular}

Table B.21. Corrected Actinide Concentrations for Pu Dissolution Experiment Pu5

\begin{tabular}{||c|c|c|c||}
\hline \hline Sample ID & Dissolution & $\mathrm{Pu}_{\text {corrected }}$ & $\mathrm{Am}_{\text {corrected }}$ \\
\hline & Time & Concentration & Concentration \\
\hline & $(\mathrm{h})$ & $(\mathrm{g} / \mathrm{L})$ & $(\mathrm{mg} / \mathrm{L})$ \\
\hline Pu5_1 & 0.25 & 1.53 & 5.98 \\
\hline Pu5_2 & 0.50 & 1.95 & 7.98 \\
\hline Pu5_3 & 0.75 & 2.81 & 11.9 \\
\hline Pu5_4 & 1.00 & 3.56 & 15.8 \\
\hline Pu5_5 & 1.25 & 4.46 & 19.1 \\
\hline Pu5_6 & 1.50 & 5.31 & 23.4 \\
\hline Pu5_7 & 1.75 & 6.27 & 27.0 \\
\hline Pu5_8 & 2.00 & 6.69 & 29.2 \\
\hline Pu5_9 & 2.25 & 6.65 & 27.9 \\
\hline
\end{tabular}




\section{$\underline{\text { Uncertainty in Pu Concentrations Based on Metal Mass }}$}

The expected concentration of $\mathrm{Pu}$ at the end of the dissolution $\left(\mathrm{C}_{\mathrm{Pu}_{\text {final }}}\right)$ was calculated from the mass of metal $\left(\mathrm{M}_{\mathrm{Pu}}\right)$ and the initial volume $\left(\mathrm{V}_{0}\right)$ of solution used in the experiment (Table 3-4). The calculation is illustrated by equation B.2.

$$
\mathrm{C}_{\mathrm{Pu}_{\text {final }}}=\frac{\mathrm{M}_{\mathrm{Pu}}}{\mathrm{V}_{0}}
$$

To calculate the uncertainty in the expected concentration, the variance in $\mathrm{C}_{\mathrm{Pu}_{\text {final }}}\left(\mathrm{V}_{\mathrm{C}_{\mathrm{Pu}_{\text {final }}}}\right)$ is initially calculated using equation B.3,

$$
\mathrm{V}_{\mathrm{C}_{\mathrm{P}_{\text {final }}}}=\left(\frac{\partial \mathrm{C}_{\mathrm{Pu}_{\text {final }}}}{\partial \mathrm{M}_{\mathrm{Pu}}}\right)^{2} \mathrm{~V}_{\mathrm{M}_{\mathrm{Pu}}}+\left(\frac{\partial \mathrm{C}_{\mathrm{Pu}_{\text {final }}}}{\partial \mathrm{V}_{0}}\right)^{2} \mathrm{~V}_{\mathrm{V}_{0}}
$$

where $\mathrm{V}_{\mathrm{M}_{\mathrm{Pu}}}$ and $\mathrm{V}_{\mathrm{V}_{0}}$ are the variances in the mass of metal and the initial volume of solution used in the experiment. The one sigma uncertainty $\left(\mathrm{s}_{\mathrm{C}_{\mathrm{P}_{\mathrm{final}}}}\right)$ is subsequently calculated from equation B.4.

$$
\mathrm{S}_{\mathrm{C}_{\mathrm{P}_{\text {ufinal }}}}=\sqrt{\left(\frac{1}{\mathrm{~V}_{0}}\right)^{2} \mathrm{~V}_{\mathrm{M}_{\mathrm{Pu}}}+\left(-\frac{\mathrm{M}_{\mathrm{Pu}}}{\mathrm{V}_{0}^{2}}\right)^{2} \mathrm{~V}_{\mathrm{V}_{0}}}
$$

The uncertainties in the Pu concentrations calculated from the metal masses and initial volume of solution were based on a $1 \%$ relative standard deviation in each of the measurements. The uncertainties are given in Table 3-4.

\section{Mass of Pu/Am Metal Dissolved}

To calculate the amount of Pu and Am metal dissolved as a function of time, the estimated solution volume (Tables B.12 - B.16) and the Pu and Am concentrations (Tables B.17 - B.21) at each sample time were used to calculate the mass of $\mathrm{Pu}$ and $\mathrm{Am}$ in solution. The calculated mass was expressed as a percentage of the total mass dissolved based on the maximum mass of Pu and Am in solution at the end of the experiment. The calculations are summarized in Tables B.22 B.26. 
Table B.22. Actinide Metal Dissolved during Experiment Pu1

\begin{tabular}{||c|c|c|c|c|c||}
\hline Sample ID & Dissolution & Pu Mass & Am Mass & Pu & Am \\
\hline & Time & Dissolved & Dissolved & Dissolved & Dissolved \\
\hline & $(\mathrm{h})$ & $(\mathrm{g})$ & $(\mathrm{g})$ & $(\%)$ & $(\%)$ \\
\hline $\mathrm{Pu} \_10$ & 0.17 & 0.536 & 2.17 & 13.5 & 12.7 \\
\hline $\mathrm{Pu} 2$ & 0.33 & 1.71 & 8.09 & 42.9 & 47.2 \\
\hline $\mathrm{Pu} 3$ & 0.50 & 2.64 & 11.5 & 66.4 & 67.0 \\
\hline $\mathrm{Pu} 44$ & 0.67 & 2.87 & 13.8 & 72.1 & 80.5 \\
\hline $\mathrm{Pu} 55$ & 0.83 & 3.46 & 15.2 & 87.0 & 88.8 \\
\hline $\mathrm{Pu} 66$ & 1.00 & 3.77 & 16.5 & 94.8 & 96.5 \\
\hline $\mathrm{Pu} 7$ & 1.17 & 3.72 & 16.4 & 93.6 & 95.7 \\
\hline $\mathrm{Pu} 8$ & 1.33 & 3.98 & 17.1 & 100 & 100 \\
\hline \hline
\end{tabular}

Table B.23. Actinide Metal Dissolved during Experiment Pu2

\begin{tabular}{|c|c|c|c|c|c||}
\hline \hline Sample ID & Dissolution & Pu Mass & Am Mass & Pu & Am \\
\hline & Time & Dissolved & Dissolved & Dissolved & Dissolved \\
\hline & (h) & $(\mathrm{g})$ & $(\mathrm{g})$ & $(\%)$ & $(\%)$ \\
\hline Pu2_1 & 0.25 & 0.322 & 1.70 & 10.9 & 13.1 \\
\hline Pu2_2 & 0.50 & 0.686 & 3.06 & 23.3 & 23.5 \\
\hline Pu2_3 & 0.75 & 1.03 & 4.23 & 34.8 & 32.6 \\
\hline Pu2_4 & 1.00 & 1.21 & 5.37 & 41.0 & 41.3 \\
\hline Pu2_5 & 1.25 & 1.53 & 6.42 & 51.9 & 49.5 \\
\hline Pu2_6 & 1.50 & 1.69 & 7.34 & 57.4 & 56.5 \\
\hline Pu2_7 & 1.75 & 1.81 & 8.23 & 61.4 & 63.4 \\
\hline Pu2_8 & 2.00 & 2.09 & 8.98 & 71.0 & 69.2 \\
\hline Pu2_9 & 2.25 & 2.19 & 9.71 & 74.3 & 74.8 \\
\hline Pu2_10 & 2.50 & 2.54 & 10.4 & 86.0 & 79.8 \\
\hline Pu2_11 & 2.75 & 2.61 & 11.1 & 88.4 & 85.7 \\
\hline Pu2_12 & 3.00 & 2.69 & 11.4 & 91.4 & 87.8 \\
\hline Pu2_13 & 3.25 & 2.69 & 11.8 & 91.1 & 90.8 \\
\hline Pu2_14 & 3.50 & 2.95 & 12.3 & 100.0 & 94.5 \\
\hline Pu2_15 & 3.75 & 2.71 & 12.4 & 95.7 & 95.7 \\
\hline Pu2_16 & 4.00 & 2.93 & 13.0 & 100 & 100 \\
\hline Pu2_17 & 4.25 & 2.87 & 12.5 & 96.6 & 96.6 \\
\hline
\end{tabular}


Table B.24. Actinide Metal Dissolved during Experiment Pu3

\begin{tabular}{||c|c|c|c|c|c||}
\hline \hline Sample ID & Dissolution & Pu Mass & Am Mass & Pu & Am \\
\hline & Time & Dissolved & Dissolved & Dissolved & Dissolved \\
\hline & $(\mathrm{h})$ & $(\mathrm{g})$ & $(\mathrm{g})$ & $(\%)$ & $(\%)$ \\
\hline Pu3_1 & 0.25 & 0.944 & 4.94 & 27.4 & 33.0 \\
\hline Pu3_2 & 0.50 & NA & NA & NA & NA \\
\hline Pu3_3 & 0.75 & 1.91 & 9.33 & 55.4 & 62.3 \\
\hline Pu3_4 & 1.00 & 2.07 & 11.3 & 60.1 & 75.3 \\
\hline Pu3_5 & 1.25 & 2.79 & 13.4 & 81.1 & 89.7 \\
\hline Pu3_6 & 1.50 & 3.31 & 15.0 & 96.2 & 100 \\
\hline Pu3_7 & 1.75 & 2.82 & 15.0 & 81.9 & 100 \\
\hline Pu3_8 & 2.00 & 3.45 & 14.4 & 100 & 95.8 \\
\hline Pu3_9 & 2.25 & 2.97 & 14.4 & 86.2 & 96.4 \\
\hline
\end{tabular}

Table B.25. Actinide Metal Dissolved during Experiment Pu4

\begin{tabular}{||c|c|c|c|c|c||}
\hline Sample ID & Dissolution & Pu Mass & Am Mass & Pu & Am \\
\hline & Time & Dissolved & Dissolved & Dissolved & Dissolved \\
\hline & (h) & $(\mathrm{g})$ & $(\mathrm{g})$ & $(\%)$ & $(\%)$ \\
\hline Pu4_1 & 0.25 & 1.62 & 7.18 & 44.5 & 44.9 \\
\hline Pu4_2 & 0.50 & 2.87 & 12.6 & 78.4 & 79.1 \\
\hline Pu4_3 & 0.75 & 3.63 & 15.8 & 99.3 & 98.7 \\
\hline Pu4_4 & 1.00 & 3.60 & 16.0 & 98.5 & 100 \\
\hline Pu4_5 & 1.25 & 3.66 & 15.8 & 100 & 98.7 \\
\hline Pu4_6 & 1.50 & 3.58 & 15.5 & 98.0 & 97.1 \\
\hline Pu4_7 & 1.75 & 3.41 & 15.3 & 93.4 & 95.8 \\
\hline Pu4_8 & 2.00 & 3.38 & 15.6 & 92.6 & 97.5 \\
\hline
\end{tabular}

Table B.26. Actinide Metal Dissolved during Experiment Pu5

\begin{tabular}{||c|c|c|c|c|c||}
\hline \hline Sample ID & Dissolution & Pu Mass & Am Mass & Pu & Am \\
\hline & Time & Dissolved & Dissolved & Dissolved & Dissolved \\
\hline & $(\mathrm{h})$ & $(\mathrm{g})$ & $(\mathrm{g})$ & $(\%)$ & $(\%)$ \\
\hline Pu5_1 & 0.25 & 0.840 & 3.27 & 24.3 & 21.7 \\
\hline Pu5_2 & 0.50 & 1.06 & 4.33 & 30.6 & 28.7 \\
\hline Pu5_3 & 0.75 & 1.51 & 6.41 & 43.7 & 42.5 \\
\hline Pu5_4 & 1.00 & 1.90 & 8.42 & 55.0 & 55.8 \\
\hline Pu5_5 & 1.25 & 2.36 & 10.1 & 68.4 & 67.0 \\
\hline Pu5_6 & 1.50 & 2.79 & 12.3 & 80.7 & 81.4 \\
\hline Pu5_7 & 1.75 & 3.27 & 14.1 & 94.5 & 93.2 \\
\hline Pu5_8 & 2.00 & 3.46 & 15.1 & 100 & 100 \\
\hline Pu5_9 & 2.25 & 3.41 & 14.3 & 98.6 & 94.5 \\
\hline \hline
\end{tabular}




\section{Uncertainties in the Masses of Pu and Am Metal Dissolved}

The amounts of $\mathrm{Pu}$ and $\mathrm{Am}$ metal dissolved as a function of time were expressed as a percentage of the total mass dissolved based on the maximum mass of Pu and Am in solution (Tables B.22B.26). This calculation is illustrated by equation B.5,

$$
\mathrm{D}(\mathrm{t})=\frac{\mathrm{M}_{\mathrm{An}(\mathrm{t})}}{\mathrm{M}_{\text {An(final) }}}(100)
$$

where $\mathrm{D}(\mathrm{t})$ is the percentage of the actinide metal dissolved, $\mathrm{M}_{\mathrm{An}(\mathrm{t})}$ is the mass of the actinide in solution at time (t), and $\mathrm{M}_{\text {An(final) }}$ is the maximum actinide mass in solution. To calculate the uncertainty in the percentage of the actinide metal dissolved, the variance in $\mathrm{D}(\mathrm{t})\left(\mathrm{V}_{\mathrm{D}(\mathrm{t})}\right)$ is initially calculated using equation B.6,

$$
\mathrm{V}_{\mathrm{D}(\mathrm{t})}=\left(\frac{\partial \mathrm{D}(\mathrm{t})}{\partial \mathrm{M}_{\mathrm{An}(\mathrm{t})}}\right)^{2} \mathrm{~V}_{\mathrm{M}_{\mathrm{An}(\mathrm{t})}}+\left(\frac{\partial \mathrm{D}(\mathrm{t})}{\partial \mathrm{M}_{\text {An(final })}}\right)^{2} \mathrm{~V}_{\mathrm{M}_{\mathrm{An}(\text { final })}}
$$

where $\mathrm{V}_{\mathrm{M}_{\mathrm{An}(\mathrm{t})}}$ and $\mathrm{V}_{\mathrm{M}_{\mathrm{An}(\text { final })}}$ are the variances in the mass of the actinide in solution at time (t) and the maximum actinide mass in solution, respectively. The one sigma uncertainty $\left(\mathrm{s}_{\mathrm{D}(\mathrm{t})}\right)$ is subsequently calculated from equation B.7.

$$
\mathrm{S}_{\mathrm{D}(\mathrm{t})}=\sqrt{\left(\frac{100}{\mathrm{M}_{\mathrm{An}(\text { final })}}\right)^{2} \mathrm{~V}_{\mathrm{M}_{\mathrm{An}(\mathrm{t})}}+\left(-\frac{100 \mathrm{M}_{\mathrm{An}(\mathrm{t})}}{\mathrm{M}_{\mathrm{An}(\text { final })}{ }^{2}}\right)^{2} \mathrm{~V}_{\mathrm{M}_{\mathrm{An}(\text { final })}}}
$$

The uncertainties in the amount of Pu and Am metal dissolved as a function of time are given in

\begin{tabular}{|c|c|c|c|c|c|}
\hline "Sample ID & Dissolution & $\mathrm{Pu}$ & Am & $\mathrm{Pu}$ & Am \\
\hline & Time & Dissolved & Dissolved & $S_{D(t)}$ & $\mathrm{S}_{\mathrm{D}(\mathrm{t})}$ \\
\hline & (h) & (\%) & $(\%)$ & $(\%)$ & $(\%)$ \\
\hline Pu_10 & 0.17 & 13.5 & 12.7 & 1.5 & 0.9 \\
\hline $\mathrm{Pu} \_2$ & 0.33 & 42.9 & 47.2 & 3.0 & 3.3 \\
\hline $\mathrm{Pu} \_3$ & 0.50 & 66.4 & 67.0 & 4.7 & 4.7 \\
\hline $\mathrm{Pu}_{-} 4$ & 0.67 & 72.1 & 80.5 & 5.1 & 5.7 \\
\hline $\mathrm{Pu} \_5$ & 0.83 & 87.0 & 88.8 & 6.1 & 6.3 \\
\hline $\mathrm{Pu} \_6$ & 1.00 & 94.8 & 96.5 & 6.7 & 6.8 \\
\hline $\mathrm{Pu} \_7$ & 1.17 & 93.6 & 95.7 & 6.6 & 6.8 \\
\hline $\mathrm{Pu} \_8$ & 1.33 & 100 & 100 & 7 & 7 \\
\hline
\end{tabular}
Tables B.27-B.31 for experiments Pu1, Pu2, Pu3, Pu4, and Pu5, respectively.

Table B.27. Uncertainties in the Actinide Metal Dissolved during Experiment Pu1 
Table B.28. Uncertainties in the Actinide Metal Dissolved during Experiment Pu2

\begin{tabular}{||c|c|c|c|c|c||}
\hline Sample ID & Dissolution & Pu & Am & Pu & Am \\
\hline & Time & Dissolved & Dissolved & $\mathrm{S}_{\mathrm{D}(\mathrm{t})}$ & $\mathrm{S}_{\mathrm{D}(\mathrm{t})}$ \\
\hline & $(\mathrm{h})$ & $(\%)$ & $(\%)$ & $(\%)$ & $(\%)$ \\
\hline Pu2_1 & 0.25 & 10.9 & 13.1 & 1.6 & 0.9 \\
\hline Pu2_2 & 0.50 & 23.3 & 23.5 & 1.8 & 1.7 \\
\hline Pu2_3 & 0.75 & 34.8 & 32.6 & 2.5 & 2.3 \\
\hline Pu2_4 & 1.00 & 41.0 & 41.3 & 2.9 & 2.9 \\
\hline Pu2_5 & 1.25 & 51.9 & 49.5 & 3.7 & 3.5 \\
\hline Pu2_6 & 1.50 & 57.4 & 56.5 & 4.1 & 4.0 \\
\hline Pu2_7 & 1.75 & 61.4 & 63.4 & 4.3 & 4.5 \\
\hline Pu2_8 & 2.00 & 71.0 & 69.2 & 5.0 & 4.9 \\
\hline Pu2_9 & 2.25 & 74.3 & 74.8 & 5.3 & 5.3 \\
\hline Pu2_10 & 2.50 & 86.0 & 79.8 & 6.1 & 5.6 \\
\hline Pu2_11 & 2.75 & 88.4 & 85.7 & 6.3 & 6.1 \\
\hline Pu2_12 & 3.00 & 91.4 & 87.8 & 6.5 & 6.2 \\
\hline Pu2_13 & 3.25 & 91.1 & 90.8 & 6.4 & 6.4 \\
\hline Pu2_14 & 3.50 & 100 & 94.5 & 7 & 6.7 \\
\hline Pu2_15 & 3.75 & 95.7 & 95.7 & 6.5 & 6.8 \\
\hline Pu2_16 & 4.00 & 100 & 100 & 7 & 7 \\
\hline Pu2_17 & 4.25 & 96.6 & 96.6 & 6.9 & 6.8 \\
\hline \hline
\end{tabular}

Table B.29. Uncertainties in the Actinide Metal Dissolved during Experiment Pu3

\begin{tabular}{||c|c|c|c|c|c||}
\hline \hline Sample ID & Dissolution & $\mathrm{Pu}$ & Am & $\mathrm{Pu}$ & $\mathrm{Am}$ \\
\hline & Time & Dissolved & Dissolved & $\mathrm{S}_{\mathrm{D}(\mathrm{t})}$ & $\mathrm{S}_{\mathrm{D}(\mathrm{t})}$ \\
\hline & $(\mathrm{h})$ & $(\%)$ & $(\%)$ & $(\%)$ & $(\%)$ \\
\hline Pu3_1 & 0.25 & 27.4 & 33.0 & 2.5 & 2.3 \\
\hline Pu3_2 & 0.50 & $\mathrm{NA}$ & NA & NA & NA \\
\hline Pu3_3 & 0.75 & 55.4 & 62.3 & 3.9 & 4.4 \\
\hline Pu3_4 & 1.00 & 60.1 & 75.3 & 4.3 & 5.3 \\
\hline Pu3_5 & 1.25 & 81.1 & 89.7 & 5.7 & 6.3 \\
\hline Pu3_6 & 1.50 & 96.2 & 100 & 6.8 & 7 \\
\hline Pu3_7 & 1.75 & 81.9 & 100 & 5.8 & 7 \\
\hline Pu3_8 & 2.00 & 100 & 95.8 & 7 & 6.8 \\
\hline Pu3_9 & 2.25 & 86.2 & 96.4 & 6.1 & 6.8 \\
\hline
\end{tabular}


Table B.30. Uncertainties in the Actinide Metal Dissolved during Experiment Pu4

\begin{tabular}{||c|c|c|c|c|c||}
\hline Sample ID & Dissolution & $\mathrm{Pu}$ & Am & $\mathrm{Pu}$ & $\mathrm{Am}$ \\
\hline & Time & Dissolved & Dissolved & $\mathrm{S}_{\mathrm{D}(\mathrm{t})}$ & $\mathrm{S}_{\mathrm{D}(\mathrm{t})}$ \\
\hline & $(\mathrm{h})$ & $(\%)$ & $(\%)$ & $(\%)$ & $(\%)$ \\
\hline $\mathrm{Pu} 4 \_1$ & 0.25 & 44.5 & 44.9 & 3.1 & 3.2 \\
\hline $\mathrm{Pu} 4 \_2$ & 0.50 & 78.4 & 79.1 & 5.5 & 5.6 \\
\hline $\mathrm{Pu} 4 \_3$ & 0.75 & 99.3 & 98.7 & 7.0 & 7.0 \\
\hline Pu4_4 & 1.00 & 98.5 & 100 & 7.0 & 7 \\
\hline Pu4_5 & 1.25 & 100 & 98.7 & 7 & 7.0 \\
\hline Pu4_6 & 1.50 & 98.0 & 97.1 & 6.9 & 6.9 \\
\hline Pu4_7 & 1.75 & 93.4 & 95.8 & 6.6 & 6.8 \\
\hline Pu4_8 & 2.00 & 92.6 & 97.5 & 6.5 & 6.9 \\
\hline
\end{tabular}

Table B.31. Uncertainties in the Actinide Metal Dissolved during Experiment Pu5

\begin{tabular}{||c|c|c|c|c|c||}
\hline \hline Sample ID & Dissolution & $\mathrm{Pu}$ & Am & $\mathrm{Pu}$ & $\mathrm{Am}$ \\
\hline & Time & Dissolved & Dissolved & $\mathrm{S}_{\mathrm{D}(\mathrm{t})}$ & $\mathrm{S}_{\mathrm{D}(\mathrm{t})}$ \\
\hline & $(\mathrm{h})$ & $(\%)$ & $(\%)$ & $(\%)$ & $(\%)$ \\
\hline Pu5_1 & 0.25 & 24.3 & 21.7 & 1.7 & 1.5 \\
\hline Pu5_2 & 0.50 & 30.6 & 28.7 & 2.2 & 2.0 \\
\hline Pu5_3 & 0.75 & 43.7 & 42.5 & 3.1 & 3.0 \\
\hline Pu5_4 & 1.00 & 55.0 & 55.8 & 3.9 & 3.9 \\
\hline Pu5_5 & 1.25 & 68.4 & 67.0 & 4.8 & 4.7 \\
\hline Pu5_6 & 1.50 & 80.7 & 81.4 & 5.7 & 5.8 \\
\hline Pu5_7 & 1.75 & 94.5 & 93.2 & 6.7 & 6.6 \\
\hline Pu5_8 & 2.00 & 100 & 100 & 7 & 7 \\
\hline Pu5_9 & 2.25 & 98.6 & 94.5 & 7.0 & 6.7 \\
\hline
\end{tabular}

$\underline{\text { Initial Dissolution Rates }}$

The surface area of the Pu metal coupons was calculated from the dimensions given in Table 2-3. Since the coupons were thin $(\sim 0.8 \mathrm{~mm})$, the calculated surface area disregards the surface area along the edges of the samples. The calculations are summarized in Table B.32.

Table B.32. Surface Area of Pu Metal Coupons

\begin{tabular}{||c|c||}
\hline Experiment & Surface Area \\
\hline & $\left(\mathrm{cm}^{2}\right)$ \\
\hline $\mathrm{Pu} 1$ & 8.509 \\
\hline $\mathrm{Pu} 2$ & 6.915 \\
\hline $\mathrm{Pu} 3$ & 7.408 \\
\hline $\mathrm{Pu} 4$ & 7.311 \\
\hline $\mathrm{Pu} 5$ & 7.492 \\
\hline
\end{tabular}

The initial rate of dissolution of the Pu metal coupons was estimated using the calculated mass of Pu dissolved during the early stage of the experiments (Tables B.22 - B.26) and the surface area of the coupons. Generally, the calculated masses of $\mathrm{Pu}$ in solution when the first and second samples were removed from the dissolver were used to calculate the mass of $\mathrm{Pu}$ dissolved 
between the two sample times. The initial mass of the coupons was not used in the calculations since $\mathrm{PuO}_{2}$ which was present on the surface of the metal would result in an under-estimation of the dissolution rate. Calculation of the dissolution rates is summarized in Table B.33.

Table B.33. Initial Pu Metal Dissolution Rates

\begin{tabular}{||c|c|c|c|c||}
\hline \hline Experiment & Pu Mass Dissolved & Pu Mass Dissolved & Dissolution & Dissolution \\
\hline & Sample 1 & Sample 2 & Time & Rate \\
\hline & $(\mathrm{g})$ & $(\mathrm{g})$ & $(\mathrm{hr})$ & $\left(\mathrm{mg} / \mathrm{min}^{\left.-\mathrm{cm}^{2}\right)}\right.$ \\
\hline $\mathrm{Pu} 1$ & 0.536 & 1.71 & 0.17 & 13.7 \\
\hline $\mathrm{Pu} 2$ & 0.322 & 0.686 & 0.25 & 3.51 \\
\hline $\mathrm{Pu} 3^{(1)}$ & 0.944 & 1.91 & 0.50 & 4.34 \\
\hline $\mathrm{Pu} 4$ & 1.62 & 2.87 & 0.25 & 11.3 \\
\hline $\mathrm{Pu} 5^{(2)}$ & 1.06 & 1.51 & 0.25 & 4.04 \\
\hline
\end{tabular}

(1) Pu dissolved based on $1^{\text {st }}$ and $3^{\text {rd }}$ samples

(2) Pu dissolved based on $2^{\text {nd }}$ and $3^{\text {rd }}$ samples

\section{Uncertainty in the Initial Pu Metal Dissolution Rates}

The initial dissolution rate of the Pu metal coupons (R) was estimated using the calculated mass of Pu dissolved during the early stage of the experiments and the surface area of the coupons (Table 3-6). The calculation is illustrated by equation B.8,

$$
\mathrm{R}=\frac{\mathrm{M}_{\mathrm{Pu}_{2}}-\mathrm{M}_{\mathrm{Pu}_{1}}}{\mathrm{At}}
$$

where $\mathrm{M}_{\mathrm{Pu}_{1}}$ and $\mathrm{M}_{\mathrm{Pu}_{2}}$ are the masses of $\mathrm{Pu}$ in solution at the two samples times, $\mathrm{A}$ is the area of the metal coupon, and $t$ is the time between samples. To calculate the uncertainty in the initial dissolution rate, the variance in $\mathrm{R}\left(\mathrm{V}_{\mathrm{R}}\right)$ is initially calculated using equation B.9,

$$
\mathrm{V}_{\mathrm{R}}=\left(\frac{\partial \mathrm{R}}{\partial \mathrm{M}_{\mathrm{Pu}_{2}}}\right)^{2} \mathrm{~V}_{\mathrm{Pu}_{2}}+\left(\frac{\partial \mathrm{R}}{\partial \mathrm{M}_{\mathrm{Pu}_{1}}}\right)^{2} \mathrm{~V}_{\mathrm{Pu}_{1}}+\left(\frac{\partial \mathrm{R}}{\partial \mathrm{A}}\right)^{2} \mathrm{~V}_{\mathrm{A}}
$$

where $\mathrm{V}_{\mathrm{Pu}_{2}}$ and $\mathrm{V}_{\mathrm{Pu}_{1}}$ are the variances in the masses of Pu in solution and $\mathrm{V}_{\mathrm{A}}$ is the variance in the area of the coupon. The uncertainty in the measured time was considered insignificant compared to the variances of the masses of Pu in solution and the area. The one sigma uncertainty $\left(s_{R}\right)$ is subsequently calculated from equation B.10.

$$
\mathrm{S}_{\mathrm{R}}=\sqrt{\left(\frac{1}{\mathrm{At}}\right)^{2} \mathrm{~V}_{\mathrm{Pu}_{2}}+\left(\frac{-1}{\mathrm{At}}\right)^{2} \mathrm{~V}_{\mathrm{Pu}_{1}}+\left(\frac{-\left(\mathrm{M}_{\mathrm{Pu}_{2}}-\mathrm{M}_{\mathrm{Pu}_{1}}\right)}{\mathrm{A}^{2} \mathrm{t}}\right)^{2} \mathrm{~V}_{\mathrm{A}}}
$$

To calculate the uncertainty in the initial dissolution rates, the variance in the surface area of the Pu metal coupons was based on a $10 \%$ relative standard deviation. The uncertainty calculations are summarized in Table B.34. 
Table B.34. Uncertainty in the Initial Pu Metal Dissolution Rates

\begin{tabular}{||c|c|c|c|c|c|c|c||}
\hline \hline Pu Mass & Std. Dev. & Pu Mass & Std. Dev. & Surface & Std. Dev. & Time & Std. Dev. \\
\hline Sample 2 & Pu Mass & Sample 1 & Pu Mass & Area & Surface & & Dissolution \\
\hline & Sample 2 & & Sample 1 & & Area & & Rate \\
\hline$(\mathrm{mg})$ & $(\mathrm{mg})$ & $(\mathrm{mg})$ & $(\mathrm{mg})$ & $\left(\mathrm{cm}^{2}\right)$ & $\left(\mathrm{cm}^{2}\right)$ & $(\mathrm{min})$ & $\left(\mathrm{mg} / \mathrm{min}^{\left.-\mathrm{cm}^{2}\right)}\right.$ \\
\hline 1710 & 85 & 536 & 53 & 8.509 & 0.851 & 10 & 1.8 \\
\hline 686 & 40 & 322 & 45 & 6.915 & 0.691 & 15 & 0.7 \\
\hline 1910 & 95 & 944 & 70 & 7.408 & 0.741 & 30 & 0.7 \\
\hline 2870 & 143 & 1620 & 81 & 7.311 & 0.731 & 15 & 1.9 \\
\hline 1510 & 76 & 1060 & 53 & 7.492 & 0.749 & 15 & 0.9 \\
\hline \hline
\end{tabular}


SRNL-STI-2012-00043

Revision 0

Appendix C Offgas Characterization 


\section{Correction Factors for Offgas Volume}

The volume of offgas collected during Experiments Pu2, Pu3, and Pu5 was corrected for the volume of liquid displaced by the Viton ${ }^{\circledR}$ tubing in the graduated cylinder and the liquid pressure head above the Tedlar ${ }^{\circledR}$ gas-collection bag. The presence of the Viton ${ }^{\circledR}$ tubing in the graduated cylinder increased the measured volume by a constant factor equal to the ratio of the cross sectional area of the tubing compared to the cross sectional area of the cylinder. Calculation of the correction factor is summarized in Table C.1.

\section{Table C.1. Correction Factor for Viton ${ }^{\circledR}$ Tubing}

\begin{tabular}{||c|c|c|c||}
\hline Offgas Component & Inside & Outside & Cross Sectional \\
\hline Component & Diameter & Diameter & Area \\
\hline & $(\mathrm{mm})$ & $(\mathrm{mm})$ & $\left(\mathrm{mm}^{2}\right)$ \\
\hline Graduated Cylinder & 58 & & 26.4 \\
\hline Viton ${ }^{\circledR}$ Tubing & & 0.68 & 0.363 \\
\hline \multicolumn{2}{|l|}{ Correction factor $=0.0137$ or $1.37 \%$} \\
\hline
\end{tabular}

The volume correction due to the water pressure on the Tedlar ${ }^{\circledR}$ gas-collection bag varies linearly with the amount of gas collected. The height of the water column for the measured volume of gases was divided by atmospheric pressure (33.9-ft or 406.8-in of water) to calculate the correction factor. The measured and calculated data are provided in Table C.2 and summarized in Figure C.1.

Table C.2. Pressure Correction for Offgas Collection System

\begin{tabular}{||c|c|c|c||}
\hline Measured & $\mathrm{H}_{2} \mathrm{O}$ Column & $\mathrm{H}_{2} \mathrm{O}$ Column & Pressure \\
\hline Volume & Height & Height & Correction \\
\hline$(\mathrm{mL})$ & $(\mathrm{mm})$ & (in) & $(\%)$ \\
\hline 50 & 150 & 5.91 & 1.45 \\
\hline 75 & 159 & 6.26 & 1.54 \\
\hline 100 & 168 & 6.61 & 1.63 \\
\hline 125 & 177 & 6.97 & 1.71 \\
\hline 150 & 186 & 7.32 & 1.80 \\
\hline 175 & 195 & 7.68 & 1.89 \\
\hline 200 & 204 & 8.03 & 1.97 \\
\hline 225 & 213 & 8.39 & 2.06 \\
\hline 250 & 222 & 8.74 & 2.15 \\
\hline 275 & 231 & 9.09 & 2.24 \\
\hline \hline
\end{tabular}


SRNL-STI-2012-00043

Revision 0

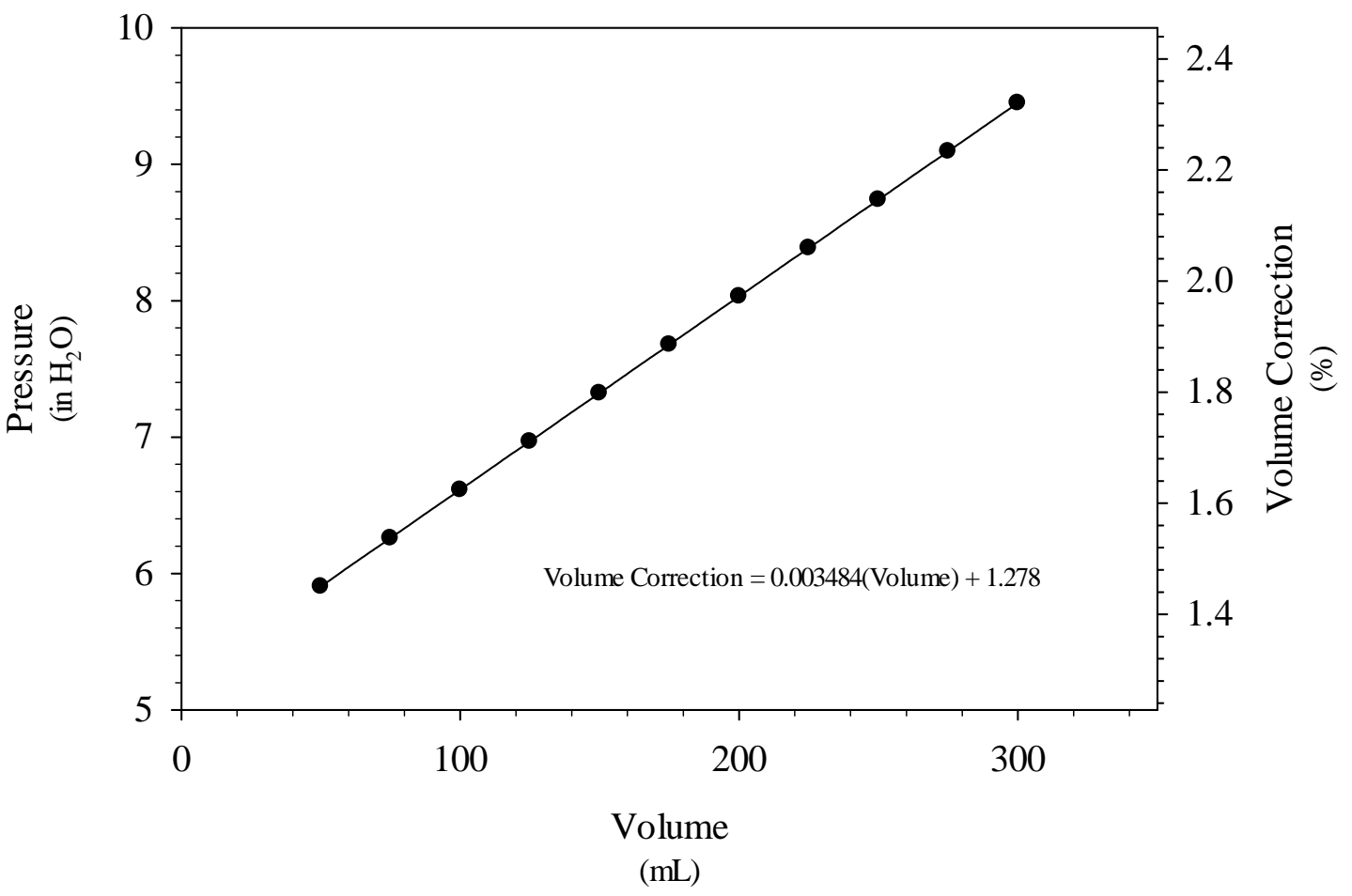

Figure C.1. Volume Corrections Due to Column of Water Above Gas-collection Bag

\section{Correction to Offgas Composition}

The analyzed composition of the offgas from the $\mathrm{Pu}$ metal dissolutions must be corrected to account for dilution from gas in the dissolution vessel, condenser, Viton ${ }^{\circledR}$ tubing, and sample bulb. To calculate the adjusted concentrations, ideal mixing of the gases in the void space is assumed and the effect of temperature variations in the gas is assumed negligible. For $\mathrm{H}_{2}$ or any other component of the offgas, the adjusted concentration is calculated by material balance,

$$
\mathrm{C}_{\text {gen }} \mathrm{V}_{\text {gen }}=\mathrm{C}_{\text {measured }}\left(\mathrm{V}_{\text {void }}+\mathrm{V}_{\text {bulb }}+\mathrm{V}_{\text {gen }}\right)-\mathrm{C}_{\text {initial }} \mathrm{V}_{\text {void }}
$$

where: $\quad \mathrm{C}_{\mathrm{gen}}=$ concentration of an offgas component in the generated gas (vol \%)

$\mathrm{C}_{\text {measured }}=$ concentration of an offgas component measured in a gas sample (vol \%)

$\mathrm{C}_{\text {initial }}=$ concentration of an offgas component before the sample collection (vol \%)

$\mathrm{V}_{\text {gen }}=$ volume of gas collected in the Tedlar ${ }^{\circledR}$ collection bag $(\mathrm{mL})$

$\mathrm{V}_{\text {void }}=$ void volume of dissolution vessel, condenser, and Viton ${ }^{\circledR}$ tubing (mL)

$\mathrm{V}_{\text {bulb }}=$ volume of the gas sample bulb $(\mathrm{mL})$.

The $\mathrm{Pu}$ metal dissolutions were performed in a 500-mL round bottom flask with a capacity of $704 \mathrm{~mL}$. The capacity was measured by filling the flask with water. The $\mathrm{Pu}$ dissolutions in Experiments Pu2, Pu3, and Pu5 were performed using 495, 546, and $550 \mathrm{~mL}$ of solution (Table 2-2), respectively; therefore, the respective void volumes of the flask were 209, 158, and $154 \mathrm{~mL}$. The void volume of the condenser and Viton ${ }^{\circledR}$ tubing used to connect the sample bulb and Tedlar $^{\circledR}$ gas-collection bag to the dissolution system were 59 and $8 \mathrm{~mL}$, respectively. The volume of the condenser was measured by filling with water and the volume of the tubing was 
calculated from the length and inside diameter. Based on these values, the void volumes of the dissolution system for Experiments Pu2, Pu3, and Pu5 were 276, 225, and $221 \mathrm{~mL}$, respectively. The volume of the gas sample bulbs was $40 \mathrm{~mL}$.

The raw gas analyses from the Pu metal dissolution experiments are show in Table C.3. The one sigma uncertainty in the analyses is $\pm 20 \%$ of the reported values.

Table C.3. Offgas Analysis for Pu Metal Dissolutions

\begin{tabular}{|c|c|c|c|c|c|}
\hline Experiment & Sample & $\mathrm{H}_{2}$ & $\mathrm{O}_{2}$ & $\mathrm{NO}$ & $\mathrm{N}_{2}$ \\
\hline & & (vol \%) & (vol \%) & (vol \%) & (vol \%) \\
\hline $\mathrm{Pu} 2$ & 1 & 0.60 & $<0.1$ & 8.4 & 89 \\
\hline $\mathrm{Pu} 2$ & 1 & 0.64 & $<0.1$ & 8.9 & 90 \\
\hline $\mathrm{Pu} 2$ & 2 & 1.90 & $<0.1$ & 21 & 76 \\
\hline $\mathrm{Pu} 2$ & 2 & 2.00 & $<0.1$ & 19 & 78 \\
\hline $\mathrm{Pu3}$ & 1 & 0.15 & $<0.1$ & 28 & 71 \\
\hline $\mathrm{Pu} 3$ & 1 & 0.15 & $<0.1$ & 27 & 72 \\
\hline $\mathrm{Pu} 3$ & 2 & 0.23 & $<0.1$ & 61 & 37 \\
\hline $\mathrm{Pu3}$ & 2 & 0.23 & $<0.1$ & 58 & 40 \\
\hline $\mathrm{Pu} 3$ & 3 & $<0.1$ & $<0.1$ & 14 & 85 \\
\hline $\mathrm{Pu3}$ & 3 & $<0.1$ & $<0.1$ & 13 & 85 \\
\hline $\mathrm{Pu} 5$ & 1 & 0.25 & $<0.1$ & 16 & 83 \\
\hline $\mathrm{Pu} 5$ & 1 & 0.30 & $<0.1$ & 13 & 86 \\
\hline $\mathrm{Pu5}$ & 2 & 0.42 & $<0.1$ & 28 & 71 \\
\hline $\mathrm{Pu5}$ & 2 & 0.41 & $<0.1$ & 26 & 73 \\
\hline
\end{tabular}

Adjusted concentrations of $\mathrm{H}_{2}$ and $\mathrm{NO}$ were calculated for Experiments Pu2, Pu3, and Pu5 using equation C.1. The volume of offgas generated during each sample period is provided in Table 3-7. To calculate the adjusted composition of the second samples collected during the dissolutions, the average concentration of the two samples from the first sample bulb was used as the initial concentration (i.e., $\mathrm{C}_{\text {initial }}$ ). Adjusted concentrations were not calculated for the third sample collected during Experiment Pu3. The adjusted concentrations are given in Table C.4.

Table C.4. Adjusted Offgas Composition from Pu Metal Dissolutions

\begin{tabular}{|c|c|c|c|}
\hline Experiment & Sample & Adjusted & Adjusted \\
\hline & & $\mathrm{H}_{2}$ Conc. & NO Conc. \\
\hline & & (vol \%) & (vol \%) \\
\hline Pu2 & 1 & 2.2 & 31 \\
\hline Pu2 & 1 & 2.4 & 33 \\
\hline Pu2 & 2 & 8.5 & 86 \\
\hline Pu2 & 2 & 9.1 & 75 \\
\hline Pu3 & 1 & 0.53 & 99 \\
\hline Pu3 & 1 & 0.53 & 95 \\
\hline Pu3 & 2 & 0.47 & 148 \\
\hline Pu3 & 2 & 0.47 & 138 \\
\hline Pu5 & 1 & 0.73 & 47 \\
\hline Pu5 & 1 & 0.88 & 38 \\
\hline Pu5 & 2 & 1.0 & 79 \\
\hline Pu5 & 2 & 0.99 & 71 \\
\hline
\end{tabular}




\section{Uncertainty in the Adjusted Gas Concentrations}

The adjusted gas concentrations $\left(\mathrm{C}_{\mathrm{gen}}\right)$ were calculated using equation C.1. To calculate the uncertainty in the concentrations, the variance in $\mathrm{C}_{\mathrm{gen}}\left(\mathrm{V}_{\mathrm{C}_{\text {gen }}}\right)$ is initially calculated using equation C.2,

$$
\mathrm{V}_{\mathrm{C}_{\text {gen }}}=\left(\frac{\partial \mathrm{C}_{\text {gen }}}{\partial \mathrm{C}_{\text {measured }}}\right)^{2} \mathrm{~V}_{\mathrm{C}_{\text {measured }}}+\left(\frac{\partial \mathrm{C}_{\text {gen }}}{\partial \mathrm{C}_{\text {intial }}}\right)^{2} \mathrm{~V}_{\mathrm{C}_{\text {initial }}}
$$

where $\mathrm{V}_{\mathrm{C}_{\text {measured }}}$ and $\mathrm{V}_{\mathrm{C}_{\text {initial }}}$ are the variances in the concentrations of the offgas component in the generated gas and the offgas component before the sample collection. The use of equation C.2 assumes the one sigma uncertainties in the volume measurements are significantly less than the $\pm 20 \%$ relative standard deviation in the gas analyses. The one sigma uncertainty in the adjusted concentrations $\left(\mathrm{s}_{\mathrm{C}_{\mathrm{gen}}}\right)$ is subsequently calculated from equation C.3.

$$
\mathrm{S}_{\mathrm{C}_{\text {gen }}}=\sqrt{\left(\frac{\mathrm{V}_{\text {void }}+\mathrm{V}_{\text {bulb }}+\mathrm{V}_{\text {gen }}}{\mathrm{V}_{\text {gen }}}\right)^{2} \mathrm{~V}_{\mathrm{C}_{\text {measured }}}+\left(\frac{-\mathrm{V}_{\text {void }}}{\mathrm{V}_{\text {gen }}}\right)^{2} \mathrm{~V}_{\mathrm{C}_{\text {initial }}}}
$$

Calculation of the relative standard deviation in the adjusted gas concentrations is summarized in Table C.5. To calculate the variance in the adjusted composition of the second samples collected during the dissolutions, the average variance in the two samples from the first sample bulb was used as the variance in the initial concentration (i.e., $\mathrm{V}_{\mathrm{C}_{\text {initial }}}$ ).

Table C.5. Uncertainty Analysis for Adjusted Gas Concentrations

\begin{tabular}{|c|c|c|c|c|c|c||}
\hline \hline Exp./Sample & Std. Dev. & Std. Dev. & Std. Dev. & Std. Dev. & Relative & Relative \\
\hline & $\mathrm{H}_{2}$ & $\mathrm{NO}$ & Adjust. $\mathrm{H}_{2}$ & Adjust. NO & Std. Dev. & Std. Dev. \\
\hline & & & & & Adjust. $\mathrm{H}_{2}$ & Adjust. NO \\
\hline & $($ vol \%) & $($ vol \%) & (vol \%) & $($ vol \%) & $(\%)$ & $(\%)$ \\
\hline Pu2/1 & 0.12 & 1.7 & 0.45 & 6.3 & 20 & 20 \\
\hline Pu2/1 & 0.13 & 1.8 & 0.48 & 6.7 & 20 & 20 \\
\hline Pu2/Ave. 1 & 0.12 & 1.7 & 0.46 & 6.5 & 20 & 20 \\
\hline Pu2/2 & 0.4 & 4 & 2.3 & 26 & 27 & 30 \\
\hline Pu2/2 & 0.4 & 4 & 2.4 & 23 & 26 & 31 \\
\hline Pu2/Ave. 2 & 0.4 & 4 & 2.3 & 25 & 27 & 31 \\
\hline Pu3/1 & 0.03 & 6 & 0.11 & 20 & 20 & 20 \\
\hline Pu3/1 & 0.03 & 5 & 0.11 & 19 & 20 & 20 \\
\hline Pu3/Ave. 1 & 0.03 & 6 & 0.11 & 19 & 20 & 20 \\
\hline Pu3/2 & 0.05 & 12 & 0.16 & 42 & 35 & 28 \\
\hline Pu3/2 & 0.05 & 12 & 0.16 & 40 & 35 & 29 \\
\hline Pu3/Ave. 2 & 0.05 & 12 & 0.16 & 41 & 35 & 29 \\
\hline Pu5/1 & 0.05 & 3 & 0.15 & 9 & 20 & 20 \\
\hline Pu5/1 & 0.06 & 3 & 0.18 & 8 & 20 & 20 \\
\hline Pu5/Ave. 1 & 0.06 & 3 & 0.16 & 9 & 20 & 20 \\
\hline Pu5/2 & 0.08 & 6 & 0.39 & 25 & 38 & 32 \\
\hline Pu5/2 & 0.08 & 5 & 0.38 & 24 & 39 & 33 \\
\hline Pu5/Ave. 2 & 0.08 & 5 & 0.38 & 24 & 38 & 32 \\
\hline \hline
\end{tabular}




\section{$\underline{\text { H-Canyon Dissolver Purge Rate }}$}

To calculate the minimum purge rate for an $\mathrm{H}$-Canyon dissolver during Pu metal dissolution, the volumetric $\mathrm{H}_{2}$ generation rate was initially calculated from the volume of offgas collected during Experiments Pu2, Pu3, and Pu5 (Table 3-7), the adjusted $\mathrm{H}_{2}$ concentrations measured in the offgas samples (Table 3-9), the masses of Pu metal dissolved (Table 2-3), and the dissolution times (Table 3-5). The $\mathrm{H}_{2}$ generation rates were scaled to an $\mathrm{H}$-Canyon dissolver based on a charge of $46 \mathrm{~kg}$ of $\mathrm{Pu}$ metal. The $\mathrm{H}_{2}$ generation rate $\left(\mathrm{G}_{\mathrm{H}_{2}}\right)$ based on the data from each experiment is calculated using equation C.4,

$$
\mathrm{G}_{\mathrm{H}_{2}}=\frac{\mathrm{V}_{\text {offgas }}}{\mathrm{t}} \frac{\mathrm{M}_{\mathrm{Pu}_{\text {dissolver }}}}{\mathrm{M}_{\mathrm{Pu}_{\text {sample }}}} \frac{\mathrm{C}_{\mathrm{H}_{2}}}{100}
$$

where $\mathrm{V}_{\text {offgas }}$ is the total offgas collected, $\mathrm{t}$ is the dissolution time, $\mathrm{M}_{\mathrm{Pu}_{\text {dissolver }}}$ is the mass of $\mathrm{Pu}$ charged to an H-Canyon dissolver (i.e., $46 \mathrm{~kg}$ ), $\mathrm{M}_{\mathrm{Pu}_{\text {sample }}}$ is the mass of Pu dissolved, and $\mathrm{C}_{\mathrm{H}_{2}}$ is the maximum $\mathrm{H}_{2}$ concentration measured in the offgas.

Since offgas collection during Experiment Pu2 was terminated before complete dissolution of the Pu metal, it was necessary to estimate the amount of Pu dissolved when the last offgas sample was removed at $185 \mathrm{~min}$ (Table 3-7). At $3 \mathrm{~h}$, an estimated $91.4 \%$ of the metal sample was dissolved (Table B.23) with a one sigma uncertainty of 6.5\% (Table B.28). Using this value, the estimated mass of Pu dissolved at $185 \min \left(\mathrm{M}_{\mathrm{Pu}_{185 \min }}\right)$ is calculated from equation C.5,

$$
\mathrm{M}_{\mathrm{Pu}_{185 \text { min }}}=\mathrm{M}_{\mathrm{Pu}_{\text {initial }}} \frac{\mathrm{D}_{\mathrm{Pu}_{185 \text { min }}}}{100}
$$

where $\mathrm{M}_{\mathrm{Pu}_{\text {initial }}}$ is the initial mass of $\mathrm{Pu}$ (i.e., $3.5060 \mathrm{~g}$ ) and $\mathrm{D}_{\mathrm{Pu}_{185 \min }}$ is the percentage of the mass dissolved at $185 \mathrm{~min}$ (i.e., 91.4\%). The calculated value was $3.20 \mathrm{~g}$. To calculate the uncertainty in the mass, the variance in $\mathrm{M}_{\mathrm{Pu}_{185 \min }}\left(\mathrm{V}_{\mathrm{M}_{\mathrm{P}_{185} \min }}\right)$ is initially calculated using equation C.6.

$$
\mathrm{V}_{\mathrm{M}_{\mathrm{Pu}_{185} \text { min }}}=\left(\frac{\partial \mathrm{M}_{\mathrm{Pu}_{185 \text { min }}}}{\partial \mathrm{M}_{\mathrm{Pu}_{\text {intitial }}}}\right)^{2} \mathrm{~V}_{\mathrm{M}_{\mathrm{Pu}_{\text {unitial }}}}+\left(\frac{\partial \mathrm{M}_{\mathrm{Pu}_{185 \text { min }}}}{\partial \mathrm{D}_{\mathrm{Pu}_{185 \text { min }}}}\right)^{2} \mathrm{~V}_{\mathrm{D}_{\mathrm{Pu}_{185 \text { min }}}}
$$

where $\mathrm{V}_{\mathrm{M}_{\mathrm{P}_{\text {unitial }}}}$ and $\mathrm{V}_{\mathrm{D}_{\mathrm{Pu}_{185} \text { min }}}$ are the variances in the initial mass of $\mathrm{Pu}$ and the percentage of the metal dissolved at $185 \mathrm{~min}$. The one sigma uncertainty in the mass of Pu metal dissolved at $185 \min \left(\mathrm{s}_{\mathrm{M}_{\mathrm{P}_{185} \min }}\right)$ is subsequently calculated from equation C.7.

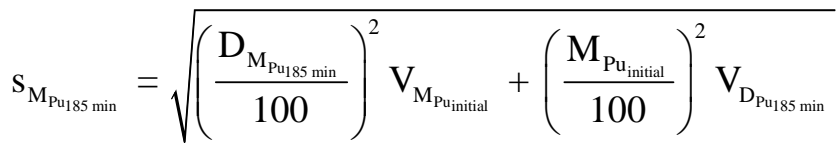

The one sigma uncertainty in the mass of Pu dissolved at 185 min was $0.23 \mathrm{~g}$. This value was calculated by assuming the relative standard deviation in the initial mass of Pu was $\pm 1 \%$. 
Equation C. 4 was used to calculate the $\mathrm{H}_{2}$ generation rate from an $\mathrm{H}$-Canyon dissolver during the dissolution of $46 \mathrm{~kg}$ of Pu metal. The calculations are based on data from Experiments Pu2, Pu3, and Pu5 and are summarized in Table C.6.

Table C.6. $\mathrm{H}_{2}$ Generation Rate from an H-Canyon Dissolver

\begin{tabular}{||c|c|c|c|c|c|c||}
\hline Exp. & Glovebox & Volume & Dissolution & Mass Pu & Maximum & $\mathrm{H}_{2}$ \\
\hline & Temp. & Offgas & time & Dissolved & $\mathrm{H}_{2}$ Conc. & Gen. Rate \\
\hline & $\left({ }^{\circ} \mathrm{C}\right)$ & $\left(\mathrm{ft}^{3} @\right.$ STP $)$ & $(\mathrm{min})$ & $(\mathrm{g})$ & $($ vol $\%)$ & $\left(\mathrm{ft}^{3} / \mathrm{min} @\right.$ STP $)$ \\
\hline $\mathrm{Pu} 2$ & 20 & $5.92 \mathrm{E}-03$ & 185 & 3.20 & 8.8 & 0.040 \\
\hline $\mathrm{Pu} 3$ & 21 & $7.54 \mathrm{E}-03$ & 120 & 3.8676 & 0.53 & 0.0039 \\
\hline Pu4 & 18.5 & $7.11 \mathrm{E}-03$ & 120 & 3.8330 & 1.0 & 0.0072 \\
\hline
\end{tabular}

STP - standard temperature and pressure

The volume of offgas collected during each experiment was converted to standard temperature and pressure using the temperature of the glovebox when the dissolutions were performed. A dissolution time of 185 min was used for Experiment Pu2 since the offgas was only collected during this portion of the dissolution. The dissolution times for experiments Pu3 and Pu4 are from Table 3-5 which were based on the corrected Pu concentrations presented in Figures 3-7 to 3-10.

To calculate the uncertainty in the $\mathrm{H}_{2}$ generation rates, the variance in $\mathrm{G}_{\mathrm{H}_{2}}\left(\mathrm{~V}_{\mathrm{G}_{\mathrm{H}_{2}}}\right)$ is initially calculated using equation C.8,

$$
\mathrm{V}_{\mathrm{G}_{\mathrm{H}_{2}}}=\left(\frac{\partial \mathrm{G}_{\mathrm{H}_{2}}}{\partial \mathrm{M}_{\mathrm{Pu}_{\text {sample }}}}\right)^{2} \mathrm{~V}_{\mathrm{M}_{\mathrm{Pu}_{\text {sample }}}}+\left(\frac{\partial \mathrm{G}_{\mathrm{H}_{2}}}{\partial \mathrm{t}}\right)^{2} \mathrm{~V}_{\mathrm{t}}+\left(\frac{\partial \mathrm{G}_{\mathrm{H}_{2}}}{\partial \mathrm{C}_{\mathrm{H}_{2}}}\right)^{2} \mathrm{~V}_{\mathrm{C}_{\mathrm{H}_{2}}}
$$

where $\mathrm{V}_{\mathrm{M}_{\mathrm{P}_{\text {uample }}}}, \mathrm{V}_{\mathrm{t}}$, and $\mathrm{V}_{\mathrm{C}_{\mathrm{H}_{2}}}$ are the variance in the mass of Pu dissolved, the dissolution time, and the maximum concentration of $\mathrm{H}_{2}$ measured in the offgas. The use of equation C.8 assumes the one sigma uncertainties in the volume measurements (i.e., $\mathrm{V}_{\text {offgas }}$ ) are significantly less than the uncertainties in the other variables. The one sigma uncertainty in the $\mathrm{H}_{2}$ generation rates $\left(\mathrm{s}_{\mathrm{G}_{\mathrm{H}_{2}}}\right)$ is subsequently calculated from equation C.9.

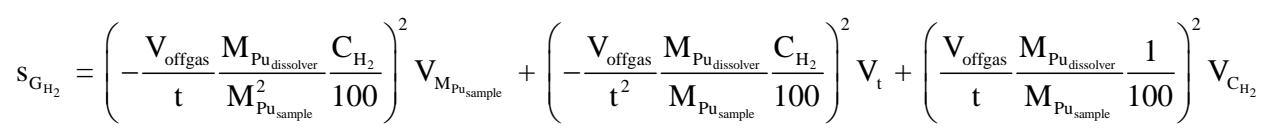

The one sigma uncertainty in the $\mathrm{H}_{2}$ generation rates from an $\mathrm{H}$-Canyon dissolver based on the data from Experiments Pu2, Pu3, and Pu5 are given in Table C.7.

Table C.7. Uncertainty in the $\mathrm{H}_{2}$ Generation Rate from an $\mathrm{H}$-Canyon Dissolver

\begin{tabular}{|c|c|c|}
\hline Experiment & Std. Dev. & Rel. Std. Dev. \\
\hline & $\mathrm{H}_{2}$ Gen. Rate & $\mathrm{H}_{2}$ Gen. Rate \\
\hline & $\left(\mathrm{ft}^{3} / \mathrm{min} @\right.$ STP $)$ & $(\%)$ \\
\hline $\mathrm{Pu} 2$ & 0.011 & 28 \\
\hline $\mathrm{Pu} 3$ & 0.0008 & 21 \\
\hline $\mathrm{Pu} 5$ & 0.0028 & 39 \\
\hline
\end{tabular}


SRNL-STI-2012-00043

Revision 0

Appendix D Dissolving Solution Characterization 


\section{Metals Analysis}

Samples of the solution following dissolution of the Pu metal coupons were analyzed for metals by ICPES. The analysis for each solution is given in Table D.1.

Table D.1. Metals Analysis for Pu Dissolution Experiments

\begin{tabular}{||c|c|c|c|c|c|c||}
\hline \hline & \multicolumn{2}{|c|}{ Pu1 } & \multicolumn{2}{c|}{ Pu2 } & \multicolumn{2}{c|}{ Pu3 } \\
\hline Element & Conc. & Relative & Conc. & Relative & Conc. & Relative \\
\hline & & Std. Dev. & & Std. Dev. & & Std. Dev. \\
\hline & (mg/L) & $(\%)$ & (mg/L) & $(\%)$ & (mg/L) & $(\%)$ \\
\hline $\mathrm{Ag}$ & $<1.46$ & NA & $<1.46$ & NA & $<1.46$ & NA \\
\hline $\mathrm{Al}$ & 14.8 & 10 & $<5.28$ & NA & 1060 & 10 \\
\hline $\mathrm{Ba}$ & $<0.52$ & NA & $<0.52$ & NA & 1.13 & 10 \\
\hline $\mathrm{Be}$ & $<0.06$ & NA & $<0.06$ & NA & $<0.16$ & NA \\
\hline $\mathrm{Ca}$ & 4.35 & 15.7 & 2.84 & 10.1 & 53.6 & 10 \\
\hline $\mathrm{Cd}$ & $<0.64$ & NA & $<0.64$ & NA & $<0.64$ & NA \\
\hline $\mathrm{Ce}$ & $<6.03$ & NA & $<6.03$ & NA & $<6.03$ & NA \\
\hline $\mathrm{Co}$ & $<0.97$ & NA & $<0.97$ & NA & $<0.97$ & NA \\
\hline $\mathrm{Cr}$ & $<6.12$ & NA & $<6.12$ & NA & $<6.12$ & NA \\
\hline $\mathrm{Cu}$ & $<6.45$ & NA & $<6.45$ & NA & $<6.45$ & NA \\
\hline $\mathrm{Fe}$ & 330 & 10 & 2030 & 10 & 2060 & 10 \\
\hline $\mathrm{Gd}$ & 398 & 10 & 501 & 10 & 999 & 10 \\
\hline $\mathrm{K}$ & 2170 & 10 & 1150 & 10 & 1860 & 10 \\
\hline $\mathrm{La}$ & $<0.86$ & NA & $<0.86$ & NA & $<0.86$ & NA \\
\hline $\mathrm{Li}$ & $<1.46$ & NA & $<1.46$ & NA & $<1.46$ & NA \\
\hline $\mathrm{Mg}$ & $<0.15$ & NA & $<0.15$ & NA & 6.88 & 10 \\
\hline $\mathrm{Mn}$ & 0.94 & 50.6 & 1.11 & 27.4 & 1.15 & 13.3 \\
\hline $\mathrm{Mo}$ & $<2.68$ & NA & $<2.68$ & NA & $<2.68$ & NA \\
\hline $\mathrm{Na}$ & 37.3 & 10.1 & 19.2 & 11.5 & 36.1 & 10.2 \\
\hline $\mathrm{Ni}$ & $<4.55$ & NA & $<4.55$ & NA & $<4.55$ & NA \\
\hline $\mathrm{P}$ & $<16.4$ & NA & $<16.4$ & NA & $<16.4$ & NA \\
\hline $\mathrm{Pb}$ & $<7.16$ & NA & $<7.16$ & NA & $<716$ & NA \\
\hline $\mathrm{S}$ & $<75$ & NA & $<75$ & NA & 452 & 13.8 \\
\hline $\mathrm{Sb}$ & $<10.7$ & NA & $<10.7$ & NA & $<10.7$ & NA \\
\hline $\mathrm{Sn}$ & $<11.22$ & NA & $<11.22$ & NA & 8.14 & 11.6 \\
\hline $\mathrm{Sr}$ & $<0.05$ & NA & $<0.05$ & NA & 0.33 & 10 \\
\hline $\mathrm{Th}$ & $<4.66$ & NA & $<4.66$ & NA & $<4.66$ & NA \\
\hline $\mathrm{Ti}$ & $<0.13$ & NA & $<0.13$ & NA & $<0.13$ & NA \\
\hline $\mathrm{U}$ & $<80.8$ & NA & $<80.8$ & NA & $<80.8$ & NA \\
\hline $\mathrm{V}$ & $<0.47$ & NA & $<0.47$ & NA & $<0.47$ & NA \\
\hline $\mathrm{Zn}$ & 7.97 & 10.2 & 5.57 & 11.5 & 751 & 10 \\
\hline $\mathrm{Zr}$ & $<0.55$ & NA & $<0.55$ & NA & $<0.55$ & NA \\
\hline \hline & & & & & \\
\hline
\end{tabular}


Table D.1. continued

\begin{tabular}{||c|c|c|c|c||}
\hline & \multicolumn{2}{|c|}{ Pu4 } & \multicolumn{2}{c||}{ Pu5 } \\
\hline Element & Conc. & Relative & Conc. & Relative \\
\hline & & Std. Dev. & & Std. Dev. \\
\hline & (mg/L) & $(\%)$ & (mg/L) & (\%) \\
\hline $\mathrm{Ag}$ & $<1.46$ & NA & $<1.46$ & NA \\
\hline $\mathrm{Al}$ & 208 & 10.1 & $<1.76$ & NA \\
\hline $\mathrm{B}$ & 995 & 10 & 1050 & 10 \\
\hline $\mathrm{Ba}$ & $<0.52$ & NA & $<0.52$ & NA \\
\hline $\mathrm{Be}$ & $<0.06$ & NA & $<0.06$ & NA \\
\hline $\mathrm{Ca}$ & 16.4 & 10 & 1.89 & 10 \\
\hline $\mathrm{Cd}$ & $<0.64$ & NA & $<0.64$ & NA \\
\hline $\mathrm{Ce}$ & $<6.03$ & NA & $<6.03$ & NA \\
\hline $\mathrm{Co}$ & $<0.97$ & NA & $<0.97$ & NA \\
\hline $\mathrm{Cr}$ & $<5.1$ & NA & $<5.1$ & NA \\
\hline $\mathrm{Cu}$ & $<4.3$ & NA & $<4.3$ & NA \\
\hline $\mathrm{Fe}$ & 1970 & 10 & 2050 & 10 \\
\hline $\mathrm{Gd}$ & 4.26 & 13.3 & 0.82 & 89.5 \\
\hline $\mathrm{K}$ & 3720 & 10 & 1940 & 10 \\
\hline $\mathrm{La}$ & $<0.86$ & NA & $<0.86$ & NA \\
\hline $\mathrm{Li}$ & $<1.46$ & NA & $<1.46$ & NA \\
\hline $\mathrm{Mg}$ & 1.97 & 10 & $<0.15$ & NA \\
\hline $\mathrm{Mn}$ & 0.94 & 11.9 & 1.02 & 10 \\
\hline $\mathrm{Mo}$ & $<2.68$ & NA & $<2.68$ & NA \\
\hline $\mathrm{Na}$ & 27.4 & 11.3 & 15.1 & 13.8 \\
\hline $\mathrm{Ni}$ & $<4.55$ & NA & $<4.55$ & NA \\
\hline $\mathrm{P}$ & $<16.4$ & NA & $<16.4$ & NA \\
\hline $\mathrm{Pb}$ & $<7.16$ & NA & $<7.16$ & NA \\
\hline $\mathrm{S}$ & 102 & 12.4 & $<75$ & NA \\
\hline $\mathrm{Sb}$ & $<10.7$ & NA & $<10.7$ & NA \\
\hline $\mathrm{Sn}$ & $<5.61$ & NA & $<5.61$ & NA \\
\hline $\mathrm{Sr}$ & 0.12 & 10 & $<0.05$ & NA \\
\hline $\mathrm{Th}$ & $<4.66$ & NA & $<4.66$ & NA \\
\hline $\mathrm{Ti}$ & 0.43 & 14.2 & $<0.13$ & NA \\
\hline $\mathrm{U}$ & $<80.8$ & NA & $<80.8$ & NA \\
\hline $\mathrm{V}$ & $<0.47$ & NA & $<0.47$ & NA \\
\hline $\mathrm{Zn}$ & 384 & 10 & 1.89 & 10.6 \\
\hline $\mathrm{Zr}$ & $<0.55$ & NA & $<0.55$ & NA \\
\hline & & & & \\
\hline
\end{tabular}




\section{Distribution:}
A. B. Barnes, 999-W
S. D. Fink, 773-A
B. J. Giddings, 786-5A
C. C. Herman, 999-W
S. L. Marra, 773-A
F. M. Pennebaker, 773-42A
W. R. Wilmarth, 773-A
E. A. Kyser, 773-A
R. A. Pierce, 773-A
T. S. Rudisill, 773-A
M. L. Crowder, 773-A
W. D. King, 773-42A
W. E. Daniel, 999-W
W. E. Harris, 704-2H
J. B. Schaade, 704-2H
G. J. Zachman, 225-7H
P.B. Andrews, 704-2H
S.J. Howell, 221-H
J.C. Wallace, 221-H
M. J. Swain, 703-H
W. G. Dyer, 704-2H
K.J. Gallahue, 221-H
S. L. Garrison, 704-2H
K. P. Burrows, 704-2H
J. W. Christopher, 704-2H
S.A. Thomas, 703-46A
R. R. Livingston, 730-2B
D. Stimac, 730-2B
W. H. Clifton, Jr., 704-2H
A. E. Visser, 773-A
S. A. Thomas, 703-46A 